\title{
From Aryl Iodides to 1,3-Dipoles: Design and Mechanism of a Palladium Catalyzed Multicomponent Synthesis of Pyrroles
}

\author{
Gerardo M. Torres, Jeffrey S. Quesnel, Diane Bijou and Bruce A. Arndtsen* \\ Department of Chemistry, McGill University, 801 Sherbrooke Street West, Montreal, \\ Quebec, H3A 0B8, Canada
}

\section{Table of Contents}

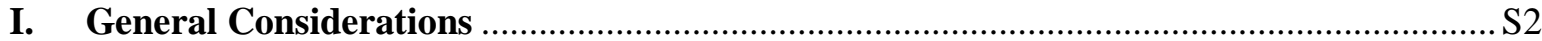

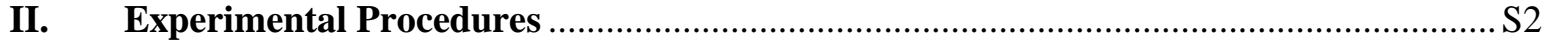

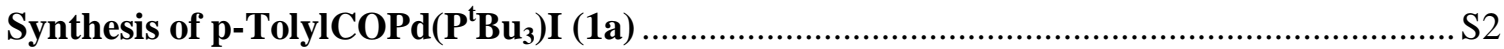

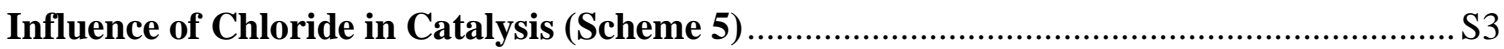

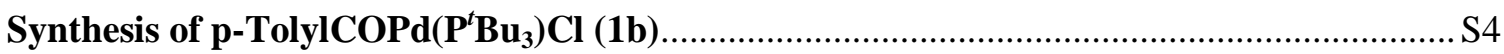

Reactivity of p-TolylCOPd $\left(\mathrm{P}^{t} \mathrm{Bu}_{3}\right) \mathrm{Cl}(1 \mathrm{~b})$ with Imine and $\mathrm{CO}$ (Scheme 6) ..........................S4

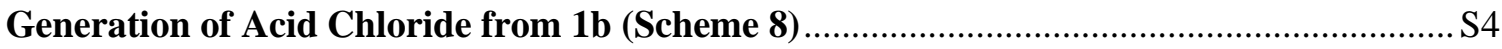

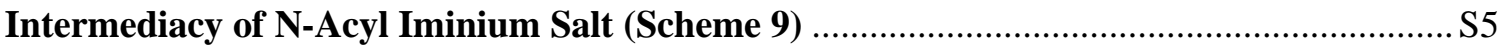

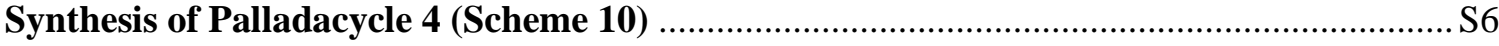

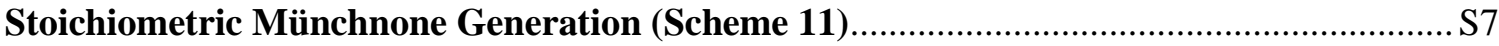

In situ ${ }^{31}$ P NMR Analysis of the Catalytic Formation of Imidazolinium Carboxylate (Figure

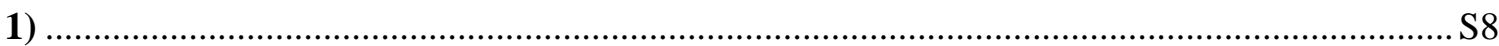

Typical Procedure for Kinetic Analysis (Figure 2) ....................................................... 8

Typical Procedure for Phosphine Ligand Screening ….................................................. S17

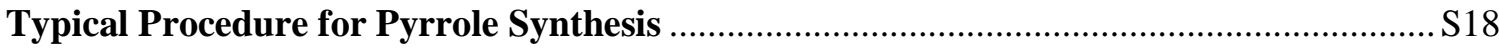

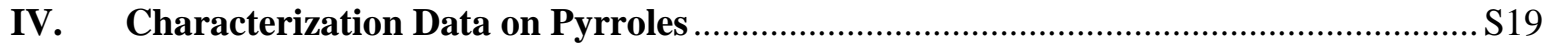

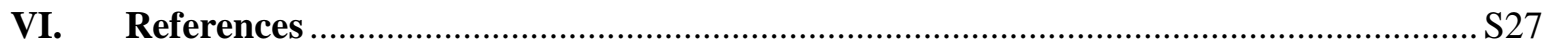

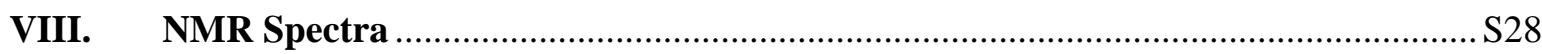




\section{General Considerations}

All manipulations were conducted in a glovebox under a nitrogen atmosphere. Unless otherwise noted, all reagents were purchased from commercial sources and used without purification. Research grade carbon monoxide (99.99\%) was used as received. Solvents were dried by using a solvent purifier system. Solvents were stored over activated $3 \AA$ molecular sieves inside the glovebox. Deuterated acetonitrile and benzene were stirred over calcium hydride, vacuum transferred, degassed, and stored over $4 \AA$ molecular sieves. Imines were prepared using standard literature procedures. ${ }^{1}$ Tetrabutylammonium chloride was dried in the glovebox by dissolving in dichloromethane, allowing to stand overnight over activated molecular sieves, filtering and removing the solvent in vacuo. $\mathrm{Pd}\left(\mathrm{P}^{t} \mathrm{Bu}_{3}\right)_{2}$ was prepared as previously described. ${ }^{2}$ All imidazolinium carboxylate products were characterized by comparison to previously prepared compounds. ${ }^{3}$

Nuclear magnetic resonance (NMR) characterization was performed on $500 \mathrm{MHz}$ spectrometers for proton, $126 \mathrm{MHz}$ for carbon, and $162 \mathrm{MHz}$ for phosphorus. ${ }^{1} \mathrm{H}$ and ${ }^{13} \mathrm{C}$ NMR chemical shifts were referenced to residual solvent. Mass spectra were recorded on a high-resolution electrospray ionization quadrupole mass spectrometer.

\section{Experimental Procedures}

\section{Synthesis of $p$-TolylCOPd $\left(\mathrm{P}^{t} \mathrm{Bu}_{3}\right) \mathrm{I}(1 \mathrm{a})$}

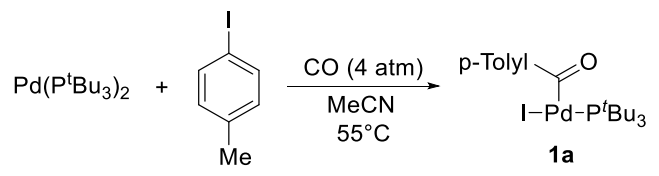

In a glovebox, 4-iodotoluene $(6.4 \mathrm{mg}, 0.0293 \mathrm{mmol}), \mathrm{Pd}\left(\mathrm{P}^{t} \mathrm{Bu}_{3}\right)_{2}(10 \mathrm{mg}, 0.0196$ $\mathrm{mmol})$, and benzyl benzoate $(4.2 \mathrm{mg}, 0.0196 \mathrm{mmol})$ were weighed. The palladium complex was dry transferred into a J-Young NMR tube, while the other two components were dissolved in $\mathrm{CD}_{3} \mathrm{CN}(0.75 \mathrm{~mL})$ and transferred into the tube. The NMR tube was then sealed with a screw-cap, taken out of the glovebox, $4 \mathrm{~atm}$ of $\mathrm{CO}$ added, and then it was warmed to $55^{\circ} \mathrm{C}$. ${ }^{1} \mathrm{H}$ NMR analysis after 20 minutes shows the formation of complex $\mathbf{1 a}$ $(84 \%)$ relative to the internal standard.

To obtain an analytically pure sample of 1a, 4-iodotoluene $(65 \mathrm{mg}, 0.30 \mathrm{mmol})$ and $\mathrm{Pd}\left(\mathrm{P}^{t} \mathrm{Bu}_{3}\right)_{2}(103 \mathrm{mg}, 0.20 \mathrm{mmol})$ were combined in a $25 \mathrm{~mL}$ Teflon-sealed glass vessel equipped with a magnetic stir bar in a glovebox. $8 \mathrm{~mL}$ acetonitrile was added (note: $\mathrm{Pd}\left(\mathrm{P}^{t} \mathrm{Bu}_{3}\right)_{2}$ is only slightly soluble in $\left.\mathrm{MeCN}\right)$. The vessel sealed, removed from the glovebox, and 4 atm of $\mathrm{CO}$ was added. Upon the addition of $\mathrm{CO}$, the mixture becomes yellow and $\mathrm{Pd}\left(\mathrm{P}^{t} \mathrm{Bu}_{3}\right)_{2}$ dissolves. The vessel was placed inside an oil bath at $55^{\circ} \mathrm{C}$ for 16 hours, then brought back into the glovebox and the solvent was removed in vacuo. The resulting dark yellow paste was washed multiple times with small portions (ca. $2 \mathrm{~mL}$ ) of pentanes to give 1a as a yellow solid (102 $\mathrm{mg}, 92 \%$ yield $){ }^{2}$

${ }^{1} \mathrm{H}$ NMR $\left(500 \mathrm{MHz}, \mathrm{CDCl}_{3}\right): \delta 8.11(\mathrm{~d}, \mathrm{~J}=8.2 \mathrm{~Hz}, 2 \mathrm{H}), 7.18(\mathrm{~d}, \mathrm{~J}=8.2 \mathrm{~Hz}, 2 \mathrm{H})$, $2.38(\mathrm{~s}, 3 \mathrm{H}), 1.43(\mathrm{~d}, \mathrm{~J}=12.8 \mathrm{~Hz}, 27 \mathrm{H}) .{ }^{13} \mathrm{C} \mathrm{NMR}\left(126 \mathrm{MHz}, \mathrm{CDCl}_{3}\right): 195.6(\mathrm{~d}, \mathrm{~J}=4.6$ $\mathrm{Hz}), 144.1,132.6$ (d, J = 13.7 Hz), 131.6, 128.9, 39.9 (d, J = 7.3 Hz), $32.2(\mathrm{~J}=4.6 \mathrm{~Hz})$, 21.7. ${ }^{31} \mathrm{P}$ NMR $\left(162 \mathrm{MHz}, \mathrm{CDCl}_{3}\right): \delta$ 71.2. Analysis for $\mathrm{C}_{20} \mathrm{H}_{34} \mathrm{IOPPd}$, Theory: $43.30 \% \mathrm{C}$, $6.18 \% \mathrm{H}$, Found: $43.49 \% \mathrm{C}, 6.26 \% \mathrm{H}$. 


\section{Reactivity of $p$-TolylCOPd $\left(\mathrm{P}^{t} \mathrm{Bu}_{3}\right) \mathrm{I}(1 \mathrm{a})$ with Imine and $\mathrm{CO}$ (Scheme 3)}

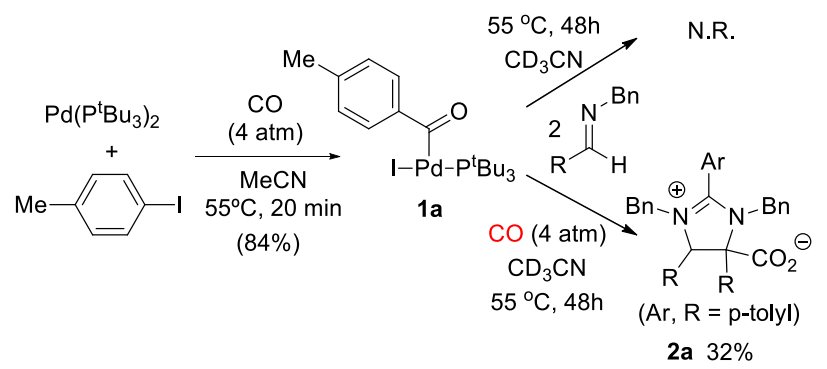

In a glove box, $p$-TolylCOPd( $\left.\mathrm{P}^{t} \mathrm{Bu}_{3}\right) \mathrm{I} \mathbf{1 a}(4.0 \mathrm{mg}, 0.0072 \mathrm{mmol}),(p-\mathrm{Tolyl}) \mathrm{CH}=\mathrm{NBn}$ (3.0 $\mathrm{mg}, 0.0144 \mathrm{mmol})$, and benzyl benzoate standard $(1.0 \mathrm{mg}, 0.0045 \mathrm{mmol})$ were dissolved in $0.75 \mathrm{~mL} \mathrm{CD}_{3} \mathrm{CN}$ and transferred into a J-Young NMR tube. The tube was sealed, taken out of the glovebox, and warmed to $55^{\circ} \mathrm{C}$ for $48 \mathrm{~h} .{ }^{1} \mathrm{H}$ NMR analysis shows no change in the integrations for any of the components in the mixture and no new signals appear. The above procedure was repeated with the addition of $4 \mathrm{~atm} \mathrm{CO}$ prior to warming to $55^{\circ} \mathrm{C}$ for $48 \mathrm{~h}$. ${ }^{1} \mathrm{H}$ NMR analysis shows the formation of $\mathbf{2 a}$ in $32 \%$ yield.

\section{Influence of Chloride in Catalysis (Scheme 4)}

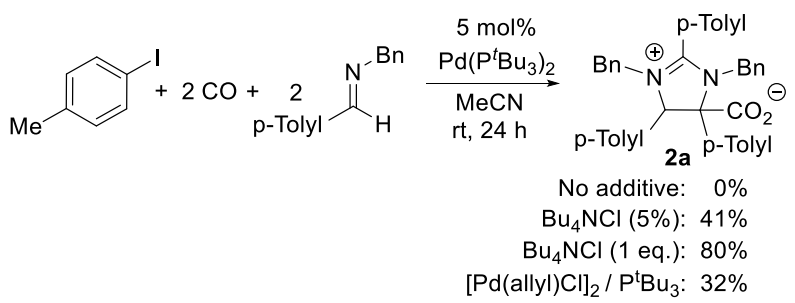

In a glovebox, 4-iodotoluene $(136 \mathrm{mg}, 0.625 \mathrm{mmol}),(p-\mathrm{Tolyl}) \mathrm{CH}=\mathrm{NBn}(26 \mathrm{mg}$, $0.125 \mathrm{mmol}),[\mathrm{Pd}(\text { allyl }) \mathrm{Cl}]_{2}(1.1 \mathrm{mg}, 0.0031 \mathrm{mmol}), \mathrm{P}^{t} \mathrm{Bu}_{3}(1.6 \mathrm{mg}, 0.0081 \mathrm{mmol})$, benzyl benzoate $(13 \mathrm{mg}, 0.0625 \mathrm{mmol})$ were dissolved in $0.75 \mathrm{~mL} \mathrm{CD}_{3} \mathrm{CN}$ and transferred into a J-Young NMR tube. The tube was then sealed with a screwcap, taken out of the glovebox,charged with $4 \mathrm{~atm}$ of $\mathrm{CO}$, and then allowed to react at ambient temperature for $24 \mathrm{~h}$ with occasional mixing. ${ }^{1} \mathrm{H}$ NMR analysis shows that $\mathbf{2 a}$ is formed in $32 \%$ yield relative to the benzyl benzoate standard.

In a glovebox, 4-iodotoluene $(136 \mathrm{mg}, 0.625 \mathrm{mmol}),(p-\mathrm{Tolyl}) \mathrm{CH}=\mathrm{NBn}(26 \mathrm{mg}$, $0.125 \mathrm{mmol}), \mathrm{Pd}\left(\mathrm{P}^{t} \mathrm{Bu}_{3}\right)_{2}(3.2 \mathrm{mg}, 0.0063 \mathrm{mmol})$, and benzyl benzoate $(13 \mathrm{mg}, 0.0625$ mmol) were dissolved in $\mathrm{CD}_{3} \mathrm{CN}$ and transferred into a J-Young NMR tube. This procedure was repeated in two other NMR tubes with in this case the addition of $\mathrm{Bu}_{4} \mathrm{NCl}(1.7 \mathrm{mg}$, $0.0063 \mathrm{mmol})$ and $\mathrm{Bu}_{4} \mathrm{NCl}(35 \mathrm{mg}, 0.125 \mathrm{mmol})$. The tubes were then sealed with a screwcap, taken out of the glovebox, charged with $4 \mathrm{~atm}$ of $\mathrm{CO}$, and allowed to react at ambient temperature for $24 \mathrm{~h}$ with occasional mixing. ${ }^{1} \mathrm{H}$ NMR analysis shows $0 \%$ of 2a was formed in the tube with no additive; while $41 \%$ was formed in the tube with catalytic amount of $\mathrm{Bu}_{4} \mathrm{NCl}$, and $80 \%$ was produced in the tube with one full equivalent of the $\mathrm{Bu}_{4} \mathrm{NCl}$. 


\section{Synthesis of $p$-TolylCOPd $\left(\mathrm{P}^{t} \mathrm{Bu}_{3}\right) \mathrm{Cl}(\mathbf{1 b})$}

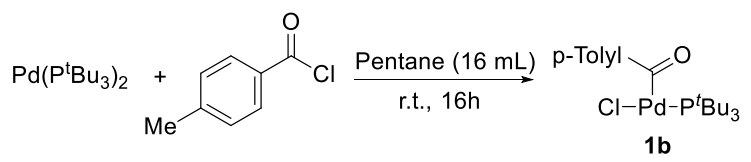

In a glove box, a $20 \mathrm{~mL}$ round bottom flask was charged with $\mathrm{Pd}\left(\mathrm{P}^{t} \mathrm{Bu}_{3}\right)_{2}(439 \mathrm{mg}$, $0.859 \mathrm{mmol}$ ), and $p$-toluoyl chloride $(266 \mathrm{mg}, 1.719 \mathrm{mmol})$ in $16 \mathrm{~mL}$ pentanes. The yellow homogeneous mixture was allowed to stand, and the product $\mathbf{1 b}$ began precipitating as a dark red solid after 30 minutes. After $16 \mathrm{~h}$, the solid was collected by filtration, and washed with pentane $(3 \times 2 \mathrm{~mL})$ to afford the analytically pure complex $\mathbf{1 b}(369 \mathrm{mg}, 93 \%$ yield). ${ }^{4}$

Orange solid. ${ }^{1} \mathrm{H}$ NMR $\left(500 \mathrm{MHz}, \mathrm{CDCl}_{3}\right): \delta 8.15(\mathrm{~d}, \mathrm{~J}=7.9 \mathrm{~Hz}, 2 \mathrm{H}), 7.20(\mathrm{~d}, \mathrm{~J}=$ $7.9 \mathrm{~Hz}, 2 \mathrm{H}), 2.37(\mathrm{~s}, 3 \mathrm{H}), 1.43(\mathrm{~d}, \mathrm{~J}=12.8 \mathrm{~Hz}, 27 \mathrm{H}) .{ }^{13} \mathrm{C} \mathrm{NMR}\left(126 \mathrm{MHz}, \mathrm{CDCl}_{3}\right): \delta 198.2$ $(\mathrm{d}, \mathrm{J}=5.5 \mathrm{~Hz}), 144.0,133.4(\mathrm{~d}, \mathrm{~J}=14.6 \mathrm{~Hz}), 131.3,129.1,39.6(\mathrm{~d}, \mathrm{~J}=9.2 \mathrm{~Hz}), 32.1(\mathrm{~d}, \mathrm{~J}=$ 4.6 Hz), 21.7. ${ }^{31} \mathrm{P}$ NMR $\left(162 \mathrm{MHz}, \mathrm{CDCl}_{3}\right): \delta$ 73.0. Analysis for $\mathrm{C}_{20} \mathrm{H}_{34} \mathrm{ClOPPd}$, Theory: $51.85 \% \mathrm{C}, 7.40 \% \mathrm{H}$, Found: $51.69 \% \mathrm{C}, 7.39 \% \mathrm{H}$.

\section{Reactivity of p-TolylCOPd $\left(\mathrm{P}^{t} \mathrm{Bu}_{3}\right) \mathrm{Cl}(1 \mathrm{~b})$ with Imine and $\mathrm{CO}$ (Scheme 5)}

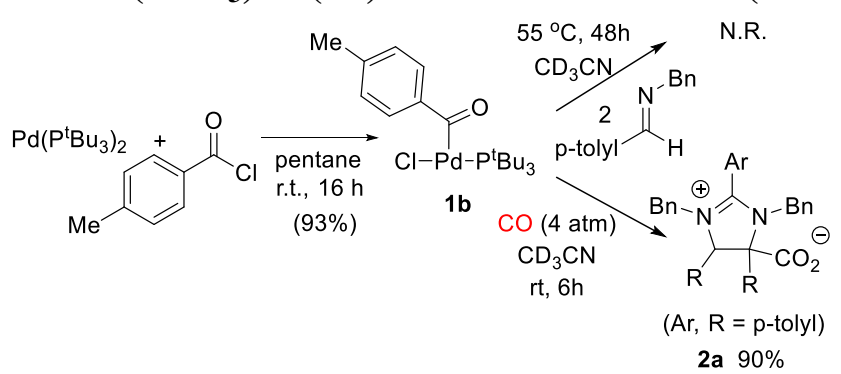

In a glove box, $1 \mathbf{b}(23 \mathrm{mg}, 0.050 \mathrm{mmol}),(p-T o l y l) \mathrm{CH}=\mathrm{NBn}(21 \mathrm{mg}, 0.100 \mathrm{mmol})$, and benzyl benzoate standard $(10.6 \mathrm{mg}, 0.0500 \mathrm{mmol})$ were dissolved in $0.75 \mathrm{~mL} \mathrm{CD} \mathrm{CN}_{3} \mathrm{CN}$ and transferred into a J-Young NMR tube. The tube was then sealed with a screwcap and taken out of the glovebox. This procedure was duplicated. One of the NMR tubes was warmed to $55^{\circ} \mathrm{C}$ for $48 \mathrm{~h}$, while the other was charged with 4 atm of $\mathrm{CO}$ and then allowed to react at ambient temperature, swirling occasionally. Both reactions were monitored via ${ }^{1} \mathrm{H}$ NMR analysis showed no formation of $\mathbf{2 a}$ in the tube without $\mathrm{CO}$; however, in the tube with CO, 2a had formed in $90 \%$ after 6 hours.

\section{Generation of Acid Chloride from 1b (Scheme 7)}

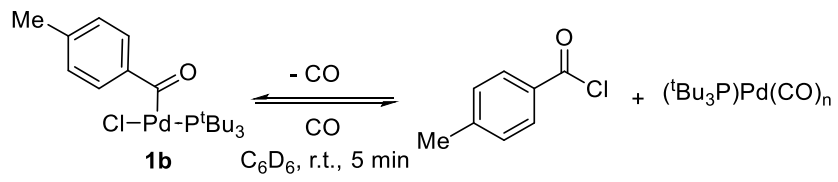

In a glove box, $1 \mathbf{b}(50 \mathrm{mg}, 0.108 \mathrm{mmol})$ and benzyl benzoate standard $(24 \mathrm{mg}$, $0.115 \mathrm{mmol}$ ) were dissolved in $3.75 \mathrm{~mL} \mathrm{C}_{6} \mathrm{D}_{6}$. Five J-Young NMR tubes were then charged each with $0.75 \mathrm{~mL}$ of the solution. The tubes were then sealed with a screwcap, taken out of the glovebox, and charged with different amounts of $\mathrm{CO}(0,1,2,3$, and $4 \mathrm{~atm})$. After ca. 5 
minutes, the mixtures were analyzed via ${ }^{1} \mathrm{H} \mathrm{NMR}$, and the yield of $p$-toluoyl chloride and 1b was determined by integration vs. the internal standard.

\begin{tabular}{cc}
\hline CO pressure (atm) & $\mathbf{\% 1 b}$ \\
\hline 0 & 0 \\
1 & 18 \\
2 & 30 \\
3 & 42 \\
4 & 52 \\
\hline
\end{tabular}

In situ ${ }^{1} \mathrm{H} \mathrm{NMR}$ analysis of the reaction with 4 atm $\mathrm{CO}$, only aromatic and tolyl signals are listed $\left(\mathrm{C}_{6} \mathrm{D}_{6}, 400 \mathrm{MHz}\right): \delta 8.42(\mathrm{~d}, \mathrm{~J}=8.1 \mathrm{~Hz}), 7.79(\mathrm{~d}, \mathrm{~J}=8.3 \mathrm{~Hz}), 6.83(\mathrm{~d}, \mathrm{~J}=7.8 \mathrm{~Hz})$, $6.65(\mathrm{~d}, \mathrm{~J}=8.1 \mathrm{~Hz}), 1.89(\mathrm{~s}), 1.82(\mathrm{~s}) .{ }^{1} \mathrm{H}$ NMR data for pure p-toluoyl chloride $\left(\mathrm{C}_{6} \mathrm{D}_{6}, 400\right.$ $\mathrm{MHz}): \delta 7.77(\mathrm{~d}, \mathrm{~J}=8.3 \mathrm{~Hz}, 2 \mathrm{H}), 6.68(\mathrm{~d}, 7.8 \mathrm{~Hz}, 2 \mathrm{H}), 1.86(\mathrm{~s}, 3 \mathrm{H}) .{ }^{1} \mathrm{H}$ NMR data for pure complex $1 \mathbf{b}\left(\mathrm{C}_{6} \mathrm{D}_{6}, 400 \mathrm{MHz}\right): \delta 8.43(\mathrm{~d}, \mathrm{~J}=7.9 \mathrm{~Hz}, 2 \mathrm{H}), 6.85(\mathrm{~d}, \mathrm{~J}=7.9 \mathrm{~Hz}, 2 \mathrm{H}), 1.90(\mathrm{~s}$, $3 \mathrm{H}), 1.12(\mathrm{~d}, 12.8 \mathrm{~Hz}, 27 \mathrm{H})$.

In situ ${ }^{13} \mathrm{C}$ NMR analysis of the reaction with 4 atm $\mathrm{CO}\left(\mathrm{C}_{6} \mathrm{D}_{6}, 100 \mathrm{MHz}\right): \delta 187.3,168.1$, 146.7, 132.2 132.0, 131.3, 130.0, 129.5, 39.5, 37.5, 32.5, 32.3, 21.7 , 21.72. ${ }^{13} \mathrm{C}$ NMR data for pure p-toluoyl chloride $\left(\mathrm{C}_{6} \mathrm{D}_{6}, 100 \mathrm{MHz}\right): \delta 168.1,147.1,132.0,131.1,130.1,21.8 .{ }^{13} \mathrm{C}$ NMR data for pure complex $\mathbf{1 b}\left(\mathrm{C}_{6} \mathrm{D}_{6}, 100 \mathrm{MHz}\right): \delta 201.0(\mathrm{~d}, \mathrm{~J}=5.5 \mathrm{~Hz}), 143.8,135.4(\mathrm{~d}$, $\mathrm{J}=13.7 \mathrm{~Hz}), 132.2,129.5,39.6(\mathrm{~d}, \mathrm{~J}=8.2 \mathrm{~Hz}), 32.4(\mathrm{~d}, \mathrm{~J}=4.6 \mathrm{~Hz}), 21.7$.

\section{Intermediacy of N-Acyl Iminium Salt (Scheme 8)}

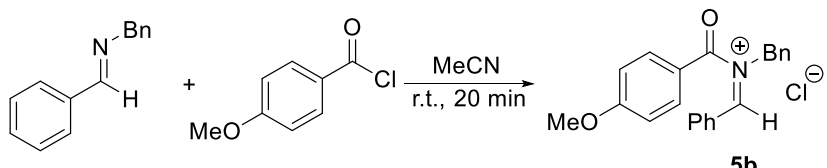

In a glovebox, $\mathrm{PhCH}=\mathrm{NBn}(100 \mathrm{mg}, 0.512 \mathrm{mmol})$ and 4- $\mathrm{MeOC}_{6} \mathrm{H}_{4} \mathrm{COCl}(114 \mathrm{mg}$, $0.666 \mathrm{mmol}$ ) were dissolved in $2 \mathrm{~mL} \mathrm{MeCN}$. The solution was allowed to stir for 20 minutes at room temperature. The solvent was then removed in vacuo and the resulting oil was washed 7 times with $1 \mathrm{~mL}$ portions of pentanes. The yellow oil was then cooled to $33^{\circ} \mathrm{C}$ for 30 minutes with a layer of pentanes on top, and a slightly yellow precipitate formed. The supernatant was decanted and the solid was dried in vacuo for several hours affording pale yellow iminium salt $\mathbf{5 b}$ (113 $\mathrm{mg}, 0.308 \mathrm{mmol}, 60 \%$ yield).

${ }^{1} \mathrm{H}$ NMR of $\mathbf{5 b}\left(400 \mathrm{MHz}, \mathrm{CD}_{3} \mathrm{CN}\right): \delta 7.60(\mathrm{~d}, \mathrm{~J}=8.8 \mathrm{~Hz}, 2 \mathrm{H}), 7.57-7.55(\mathrm{~m}, 2 \mathrm{H})$, $7.43(\mathrm{~s}, 1 \mathrm{H}), 7.39-7.33(\mathrm{~m}, 3 \mathrm{H}), 7.16(\mathrm{~d}, \mathrm{~J}=7.1 \mathrm{~Hz}, 2 \mathrm{H}), 7.08-7.05(\mathrm{~m}, 2 \mathrm{H}), 7.01(\mathrm{~d}, \mathrm{~J}=9.0$ $\mathrm{Hz}, 2 \mathrm{H}), 4.54(\mathrm{~s}, 2 \mathrm{H}), 3.83(\mathrm{~s}, 3 \mathrm{H}) .{ }^{13} \mathrm{C} \mathrm{NMR}$ of $\mathbf{5 b}\left(100 \mathrm{MHz}, \mathrm{CD}_{3} \mathrm{CN}\right): 173.7,162.9$, 139.0, 138.2, 135.4, 130.4, 130.3, 129.9, 129.4, 128.9, 128.0, 115.5, 56.7, 47.9. 


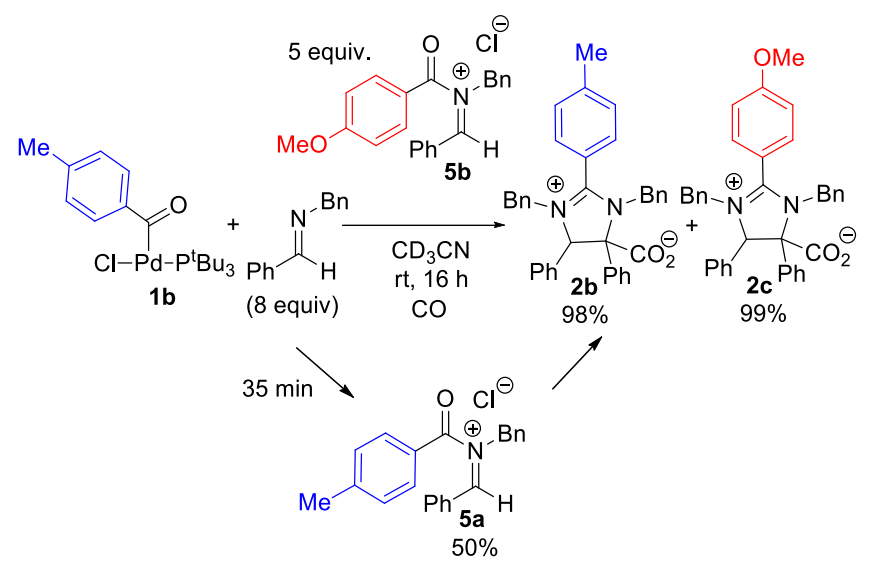

In a glove box, $\mathbf{1 b}(6.6 \mathrm{mg}, 0.0143 \mathrm{mmol}), \mathrm{PhCH}=\mathrm{NBn}(39 \mathrm{mg}, 0.200 \mathrm{mmol})$, iminium salt $5 \mathbf{b}(26 \mathrm{mg}, 0.0716 \mathrm{mmol})$, and benzyl benzoate standard $(11 \mathrm{mg}, 0.0500$ mmol) were dissolved in $0.75 \mathrm{~mL} \mathrm{CD} 3 \mathrm{CN}$ and transferred into a J-Young NMR tube. The tube was then sealed with a screw cap, taken out of the glove box, charged with 4 atm of $\mathrm{CO}$, and allowed to stand at ambient temperature. The mixture was analyzed by ${ }^{1} \mathrm{H}$ and ${ }^{31} \mathrm{P}$ NMR every 10 minutes over 2 hours. ${ }^{1} \mathrm{H}$ NMR analysis showed that iminium salt 5a was formed in 50\% yield at 35 minutes, but then it was quickly consumed over the next 30 minutes. After 16 hours, upon imidazolinium carboxylates $\mathbf{2 b}(98 \%)$ and $\mathbf{2 c}(99 \%)$ were observed. ${ }^{3}$

\section{Synthesis of Palladacycle 4 (Scheme 9)}

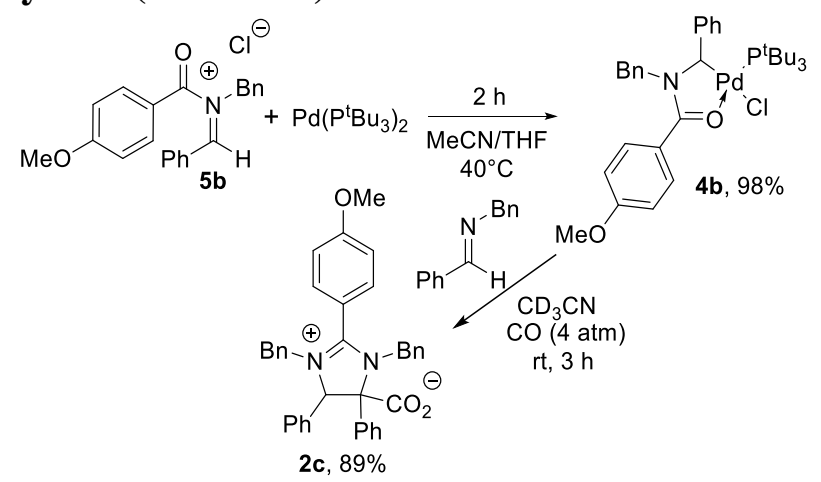

In a glove box, $\mathrm{Pd}\left(\mathrm{P}^{t} \mathrm{Bu}_{3}\right)_{2}(25 \mathrm{mg}, 0.049 \mathrm{mmol})$, iminium salt $\mathbf{5 b}(36 \mathrm{mg}, 0.098$ $\mathrm{mmol})$, and benzyl benzoate standard $(5.2 \mathrm{mg}, 0.0245 \mathrm{mmol})$ were dissolved in $0.75 \mathrm{~mL}$ THF/ $\mathrm{CD}_{3} \mathrm{CN}$ (2:1) and transferred into a J-Young NMR tube. The tube was then sealed, taken out of the glove box, and heated at $40^{\circ} \mathrm{C}$. The reaction was monitored periodically via ${ }^{1} \mathrm{H}$ NMR analysis using double solvent suppression to eliminate the signals of THF. The yield of $\mathbf{5 b}$ after $2 \mathrm{~h}$ was determined by ${ }^{1} \mathrm{H}$ NMR integration vs internal standard (98\%). The NMR tube was brought back into the glove box and PhHC=NBn (9.3 mg, 0.049 mmol) was added. The NMR tube was sealed with a screw-cap, taken out of the glovebox, charged with $4 \mathrm{~atm}$ of $\mathrm{CO}$ and allowed to react at ambient temperature. The yield of $\mathbf{2 c}$ (89\%) was calculated using ${ }^{1} \mathrm{H}$ NMR integrations.

Due to difficulties in the isolation of an analytically pure sample of complex $\mathbf{4 b}$, an analogue, $4 \mathbf{a}$, was prepared. $[\mathrm{Pd}(p \text {-tolyl }) \mathrm{HCNBnCO}(p \text {-tolyl })]_{2}$ was prepared as previously described. ${ }^{5}$ To this complex $(50 \mathrm{mg}, 0.055 \mathrm{mmol})$, tri-tert-butylphosphine (44 mg, 0.219 
mmol) was added in $5 \mathrm{~mL}$ toluene. The solution was allowed to stir at room temperature for 30 minutes. The solvent was removed in vacuo, affording an orange oil. The product was washed with $6 \times 1 \mathrm{~mL}$ portions of pentanes. Solvent traces were then removed in vacuo to afford palladacycle $\mathbf{4 a}$ as a yellow solid in $77 \%$ isolated yield $(57 \mathrm{mg}, 0.085 \mathrm{mmol})$.

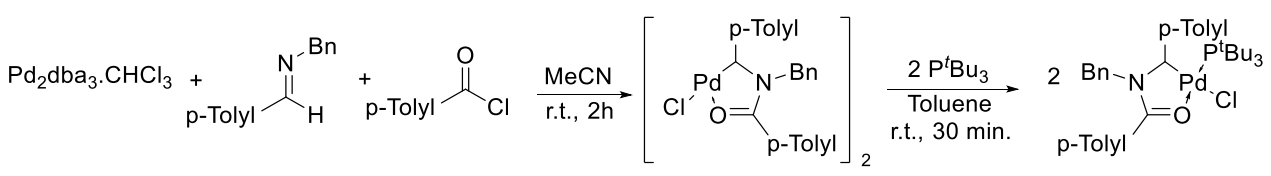

Yellow solid. ${ }^{1} \mathrm{H}$ NMR (400 MHz, $\left.\mathrm{C}_{6} \mathrm{D}_{6}\right): \delta 7.61(\mathrm{~d}, \mathrm{~J}=7.1 \mathrm{~Hz}, 2 \mathrm{H}), 7.36(\mathrm{~d}, \mathrm{~J}=7.8$ $\mathrm{Hz}, 2 \mathrm{H}), 7.07$ (d, J = 7.8 Hz, 2H), 6.99-6.91 (m, 5H), $6.75(\mathrm{~d}, \mathrm{~J}=8.1 \mathrm{~Hz}, 2 \mathrm{H}), 5.94(\mathrm{~d}, \mathrm{~J}=$ $9.3 \mathrm{~Hz}, 1 \mathrm{H}), 4.38$ (dd, J = 15.9, $2.9 \mathrm{~Hz}, 1 \mathrm{H}) 4.01(\mathrm{~d}, \mathrm{~J}=15.9 \mathrm{~Hz}, 1 \mathrm{H}), 2.05$ (s, 3H), 1.93 (s, $3 \mathrm{H}), 1.52(\mathrm{~d}, \mathrm{~J}=11.0 \mathrm{~Hz}, 27 \mathrm{H}) .{ }^{31} \mathrm{P}$ NMR $\left(162 \mathrm{MHz}, \mathrm{C}_{6} \mathrm{D}_{6}=\delta 66.4{ }^{13} \mathrm{C} \mathrm{NMR}(100 \mathrm{MHz}\right.$, $\left.\mathrm{CDCl}_{3}\right): \delta 179.7(\mathrm{~d}, \mathrm{~J}=7.3 \mathrm{~Hz}), 141.6,139.7(\mathrm{~d}, \mathrm{~J}=5.9 \mathrm{~Hz}), 135.0,134.7(\mathrm{~d}, \mathrm{~J}=2.9 \mathrm{~Hz})$, $129.8,129.5,129.3(\mathrm{~d}, \mathrm{~J}=1.5 \mathrm{~Hz}), 128.9,127.9,127.6,127.5,125.6(\mathrm{~d}, \mathrm{~J}=2.9 \mathrm{~Hz}), 69.5$ $(\mathrm{d}, \mathrm{J}=97.6 \mathrm{~Hz}), 52.5(\mathrm{~d}, \mathrm{~J}=4.4 \mathrm{~Hz}), 37.9,32.7(\mathrm{~d}, \mathrm{~J}=5.9 \mathrm{~Hz}), 21.5,21.4$. HRMS $\left(\mathrm{ESI}^{+}\right)$ for $\mathrm{C}_{35} \mathrm{H}_{48} \mathrm{NClO}_{6} \mathrm{PPd}^{+}$; calculated 670.21914 , found 670.22021 (error $\mathrm{m} / \mathrm{z}=1.6 \mathrm{ppm}$ )

\section{Stoichiometric Münchnone Generation (Scheme 10)}

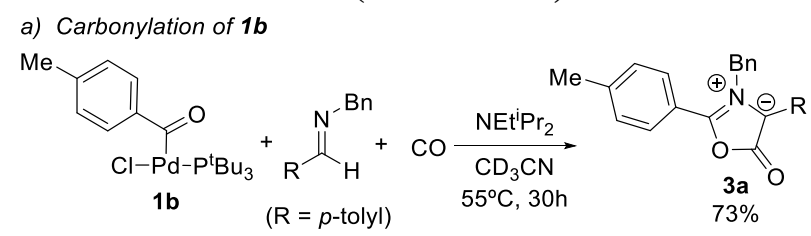

b) Carbonylation of $4 a$

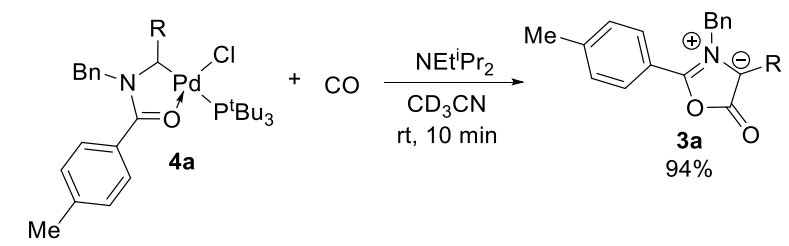

In a glove box, $1 \mathbf{b}(26 \mathrm{mg}, 0.0562 \mathrm{mmol}),(p$-Tolyl $) \mathrm{CH}=\mathrm{NBn}(12 \mathrm{mg}, 0.0562$ mmol), $\mathrm{NEt}^{i} \operatorname{Pr}_{2}$ (11 mg, $0.0843 \mathrm{mmol}$ ), and benzyl benzoate standard (12 $\mathrm{mg}, 0.0562$ mmol) were dissolved in $0.75 \mathrm{~mL} \mathrm{CD}_{3} \mathrm{CN}$ and transferred into a J-Young NMR tube. The NMR tube was then sealed with a screw cap, taken out of the glove box, charged with 4 atm of $\mathrm{CO}$ and allowed to react at $55^{\circ} \mathrm{C}$. ${ }^{1} \mathrm{H}$ NMR analysis showed the formation of $\mathbf{3 a}$ in $73 \%$ yield after 30 hours.

In a glove box, $4 \mathbf{a}(5.0 \mathrm{mg}, 0.0074 \mathrm{mmol}), \mathrm{NEt}^{i} \operatorname{Pr}_{2}(1.0 \mathrm{mg}, 0.0080 \mathrm{mmol})$, and benzyl benzoate standard $(0.8 \mathrm{mg}, 0.0037 \mathrm{mmol})$ were dissolved in $0.75 \mathrm{~mL} \mathrm{CD}_{3} \mathrm{CN}$ and transferred into a J-Young NMR tube. The NMR tube was then sealed with a screw cap, taken out of the glove box, charged with $4 \mathrm{~atm}$ of $\mathrm{CO}$, and allowed to react at ambient temperature. . ${ }^{1} \mathrm{H}$ NMR analysis after $10 \mathrm{~min}$ showed the formation of $\mathbf{3 a}$ in $94 \%$ yield. 


\section{In situ ${ }^{31}$ P NMR Analysis of the Catalytic Formation of Imidazolinium Carboxylate}

(Figure 1)

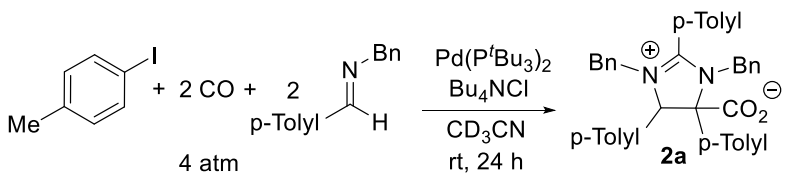

In a glove box, $\mathrm{Pd}\left(\mathrm{P}^{t} \mathrm{Bu}_{3}\right)_{2}(6.4 \mathrm{mg}, 0.0126 \mathrm{mmol})$ and $\mathrm{Bu}_{4} \mathrm{NCl}(18 \mathrm{mg}, 0.063$ mmol) were dry-transferred into a J-Young NMR tube. ( $p$-tolyl) $\mathrm{CH}=\mathrm{NBn}(13 \mathrm{mg}, 0.063$ $\mathrm{mmol}$ ) and 4-iodotoluene (69 $\mathrm{mg}, 0.315 \mathrm{mmol}$ ) were dissolved in $0.75 \mathrm{~mL} \mathrm{CD}_{3} \mathrm{CN}$ and added to the NMR tube. The NMR tube was then sealed with a screw cap, taken out of the glove box, charged with 4 atm of $\mathrm{CO}$ and allowed to react at ambient temperature. ${ }^{31} \mathrm{P}$ NMR (162 MHz) data was collected periodically. The only observable species at early reaction times were complex $\mathbf{1 b}(72.8 \mathrm{ppm})$ and free phophine $(63.4 \mathrm{ppm})$. After $8 \mathrm{~h}$, protonated phosphine was observed $(46.1 \mathrm{ppm})$ as the only phosphorus containing compound.

\section{Typical Procedure for Kinetic Analysis (Figure 2)}

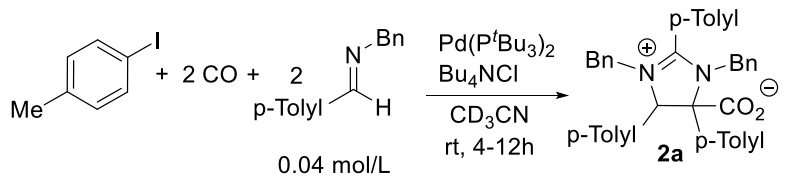

In a glove box, $\mathrm{Pd}\left(\mathrm{P}^{\mathrm{t}} \mathrm{Bu}_{3}\right)_{2}(1.6 \mathrm{mg}, 0.0031 \mathrm{mmol})$ and $\mathrm{Bu}_{4} \mathrm{NCl}(8.7 \mathrm{mg}, 0.031$ mmol) were transferred into a J-Young NMR tube. (p-tolyl) $\mathrm{CH}=\mathrm{NBn}(6.6 \mathrm{mg}, 0.031$ $\mathrm{mmol})$, 4-iodotoluene ( $68 \mathrm{mg}, 0.310 \mathrm{mmol})$, and benzyl benzoate standard (3.3 $\mathrm{mg}, 0.0156$ mmol) were dissolved in $0.75 \mathrm{~mL} \mathrm{CD} \mathrm{CD}_{3} \mathrm{CN}$ and transferred into the NMR tube. The NMR tube was then sealed with a screw cap, taken out of the glove box, and charged with 4 atm of CO. The contents of the tube were kept frozen until loading into the NMR spectrometer. An array experiment was programmed to collect ${ }^{1} \mathrm{H}$ NMR spectra starting at $\mathrm{t}=5$ minutes at $40^{\circ} \mathrm{C}$, with subsequent points collected every 15 minutes. The consumption of imine was monitored via ${ }^{1} \mathrm{H}$ NMR integration vs. the internal standard. This procedure was repeated in duplicate at different $\mathrm{CO}$ pressure, aryl iodide concentration and initial imine concentration. 


\section{A. Effect of CO Pressure on rate}

$\mathrm{CO}$ pressure $=1 \mathrm{~atm}[\mathrm{ArI}]=0.40 \mathrm{~mol} / \mathrm{L}$

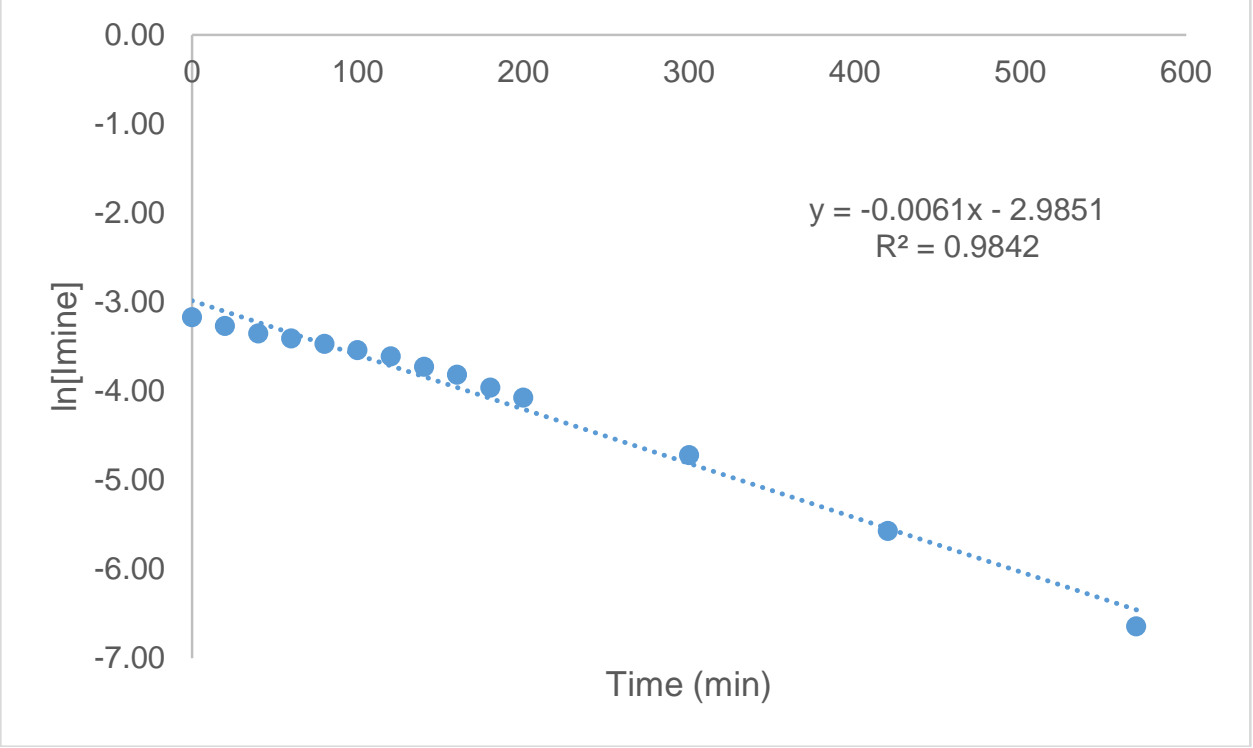

$\mathrm{CO}$ pressure $=2 \mathrm{~atm}[\mathrm{ArI}]=0.40 \mathrm{~mol} / \mathrm{L}$

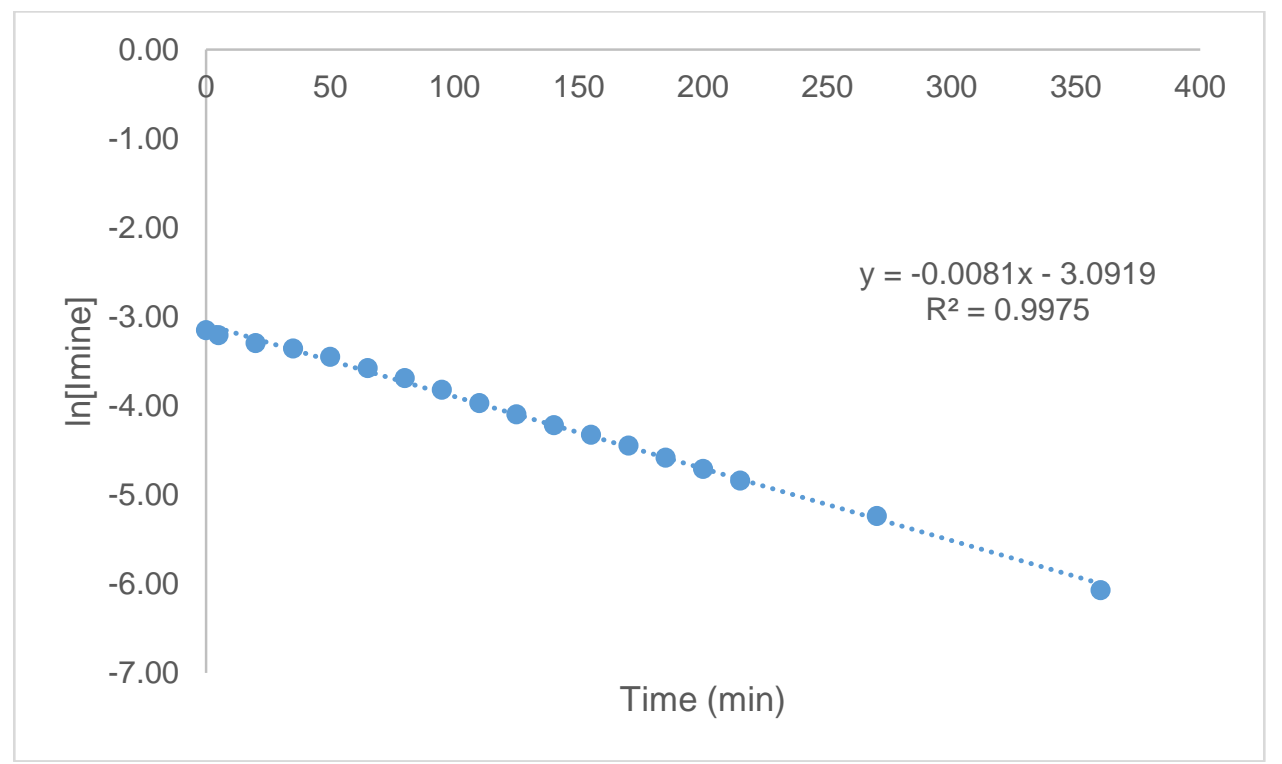


$\mathrm{CO}$ pressure $=3 \mathrm{~atm}[\mathrm{ArI}]=0.40 \mathrm{~mol} / \mathrm{L}$

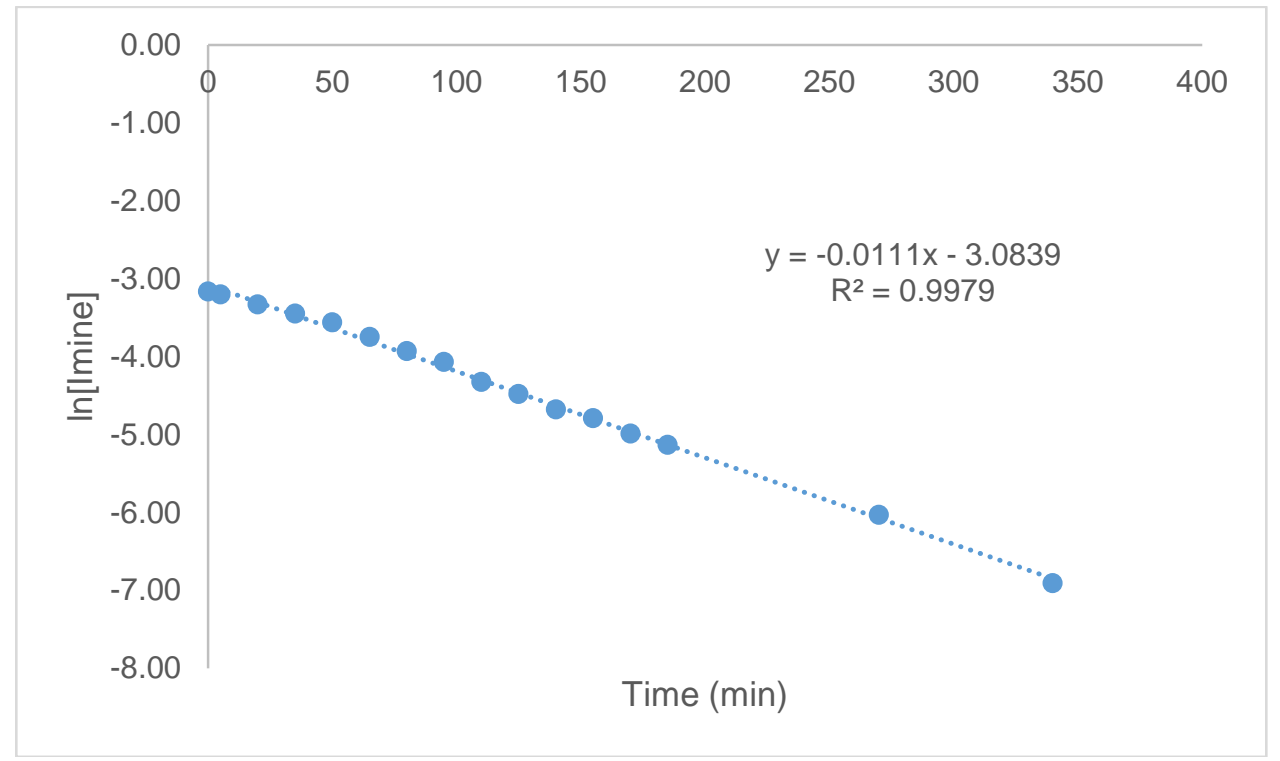

$\mathrm{CO}$ pressure $=4 \mathrm{~atm}[\mathrm{ArI}]=0.40 \mathrm{~mol} / \mathrm{L}$

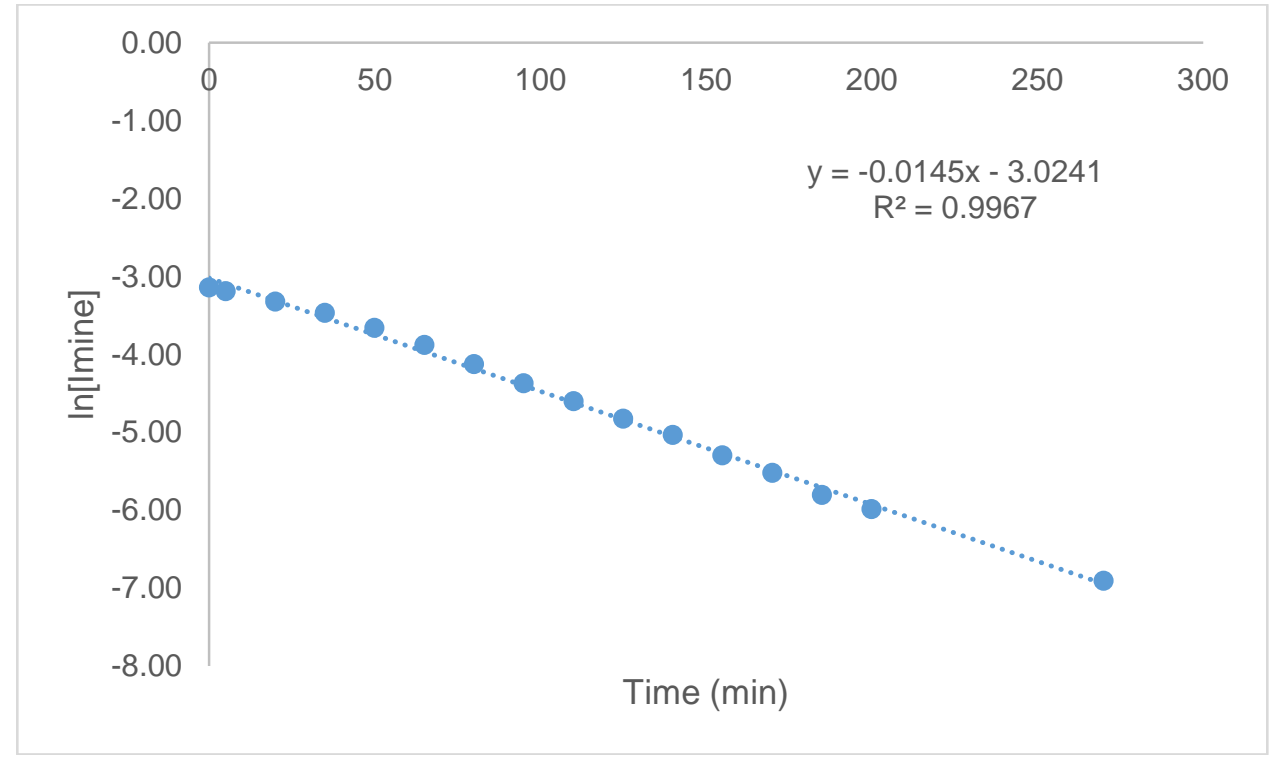


$\mathrm{CO}$ pressure $=5 \mathrm{~atm}[\mathrm{ArI}]=0.40 \mathrm{~mol} / \mathrm{L}$

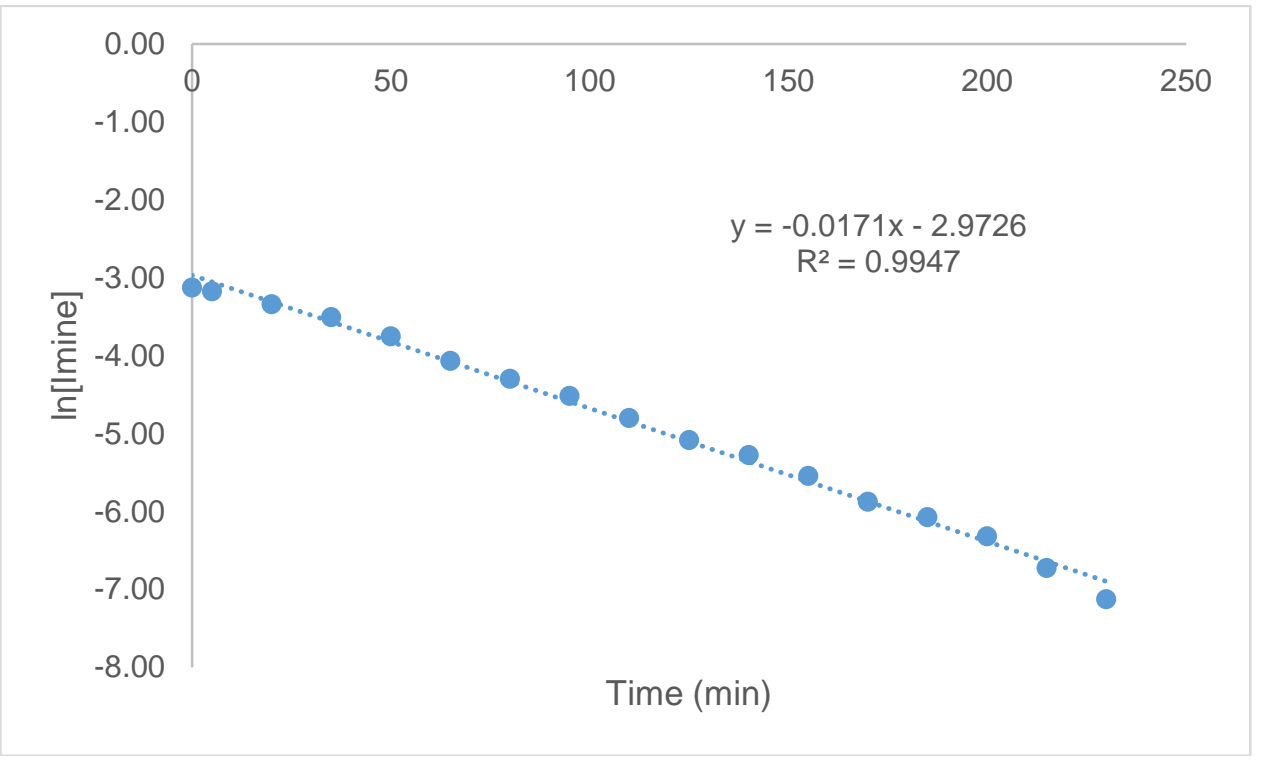

Effect of $\mathrm{CO}$ pressure on initial rate:

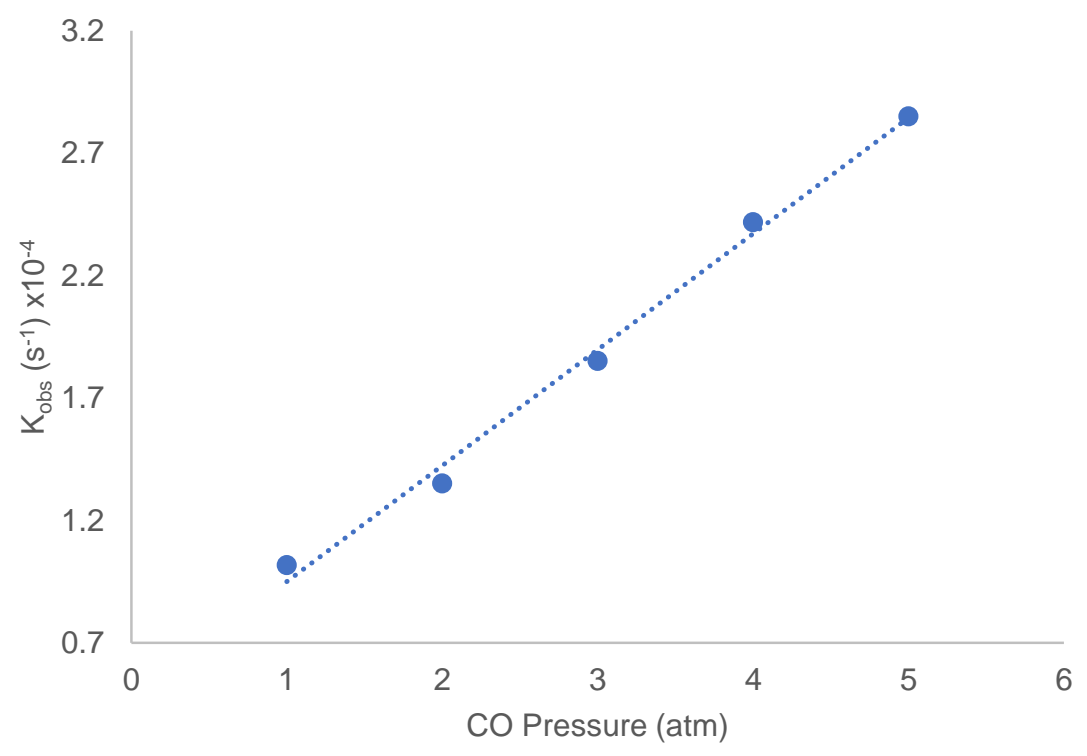




\section{B. Effect of [aryl iodide] on rate}

$\mathrm{CO}$ pressure $=4 \mathrm{~atm}[\mathrm{ArI}]=0.21 \mathrm{~mol} / \mathrm{L}$

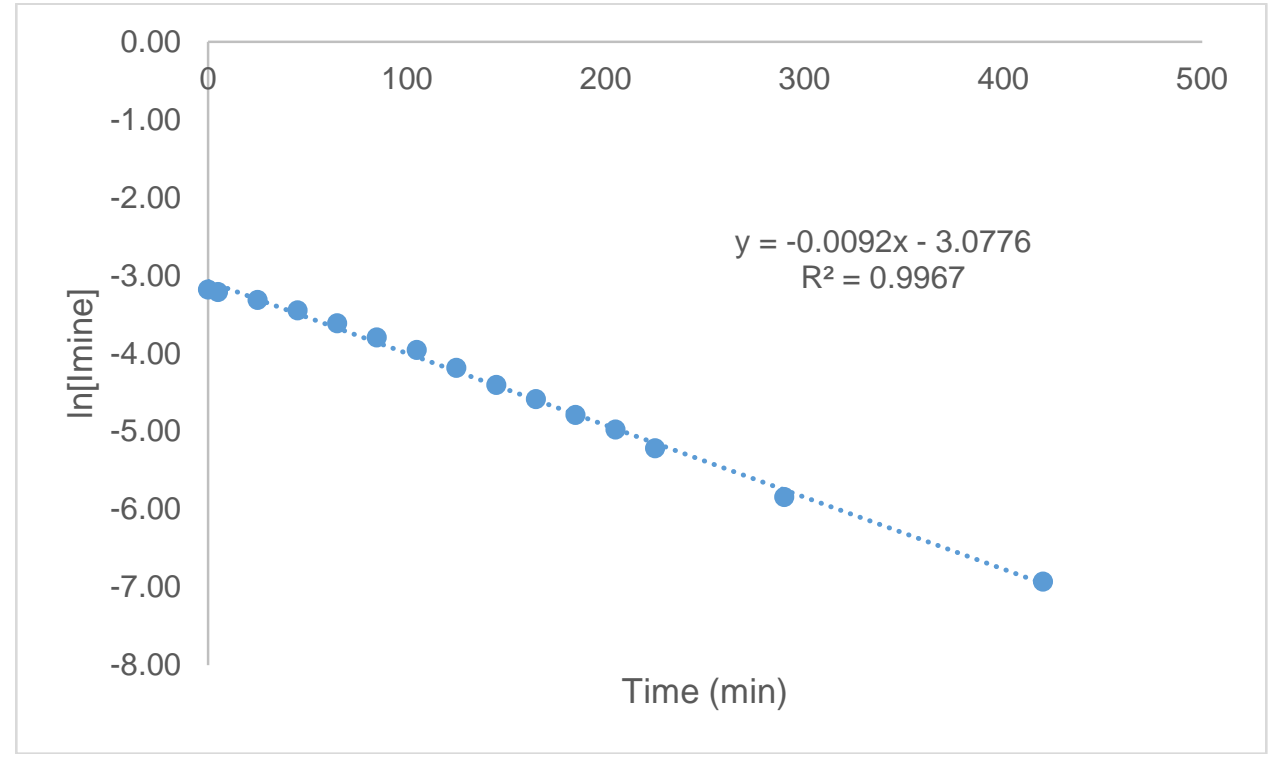

$\mathrm{CO}$ pressure $=4 \mathrm{~atm}[\mathrm{ArI}]=0.31 \mathrm{~mol} / \mathrm{L}$

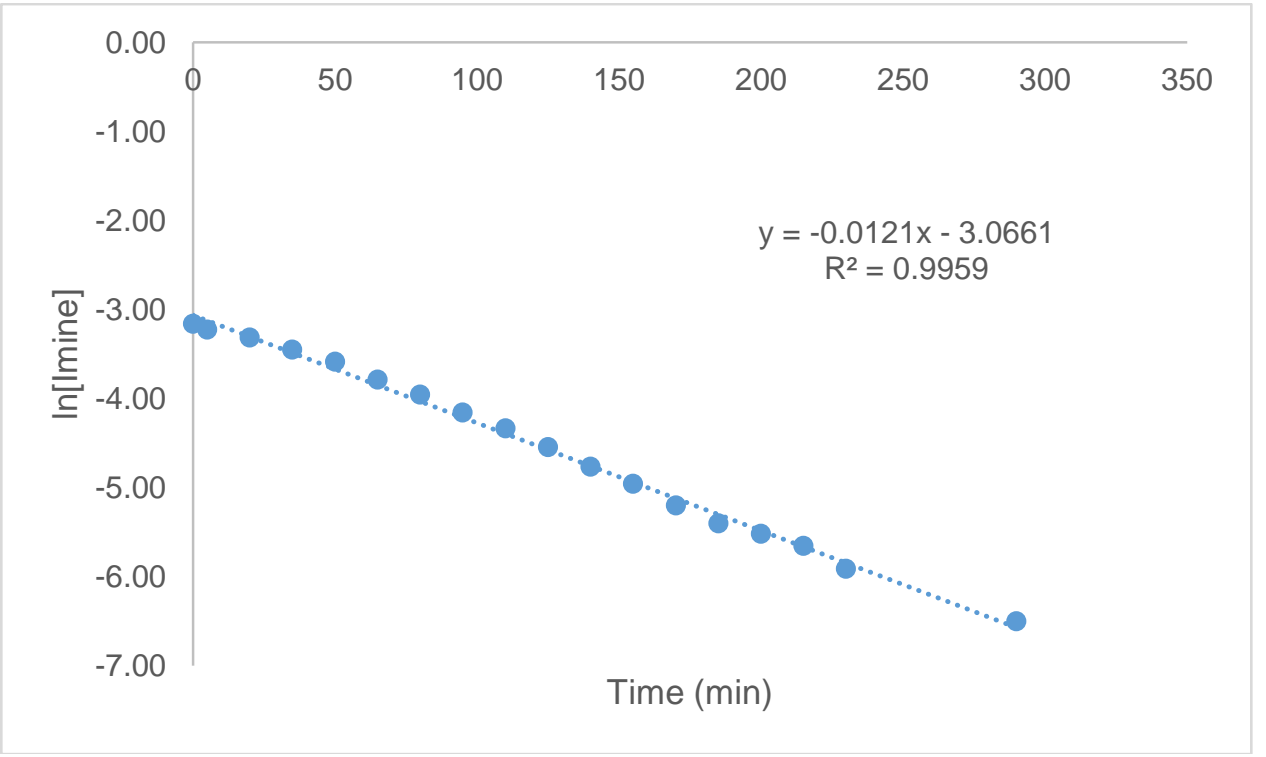


$\mathrm{CO}$ pressure $=4 \mathrm{~atm}[\mathrm{ArI}]=0.40 \mathrm{~mol} / \mathrm{L}$

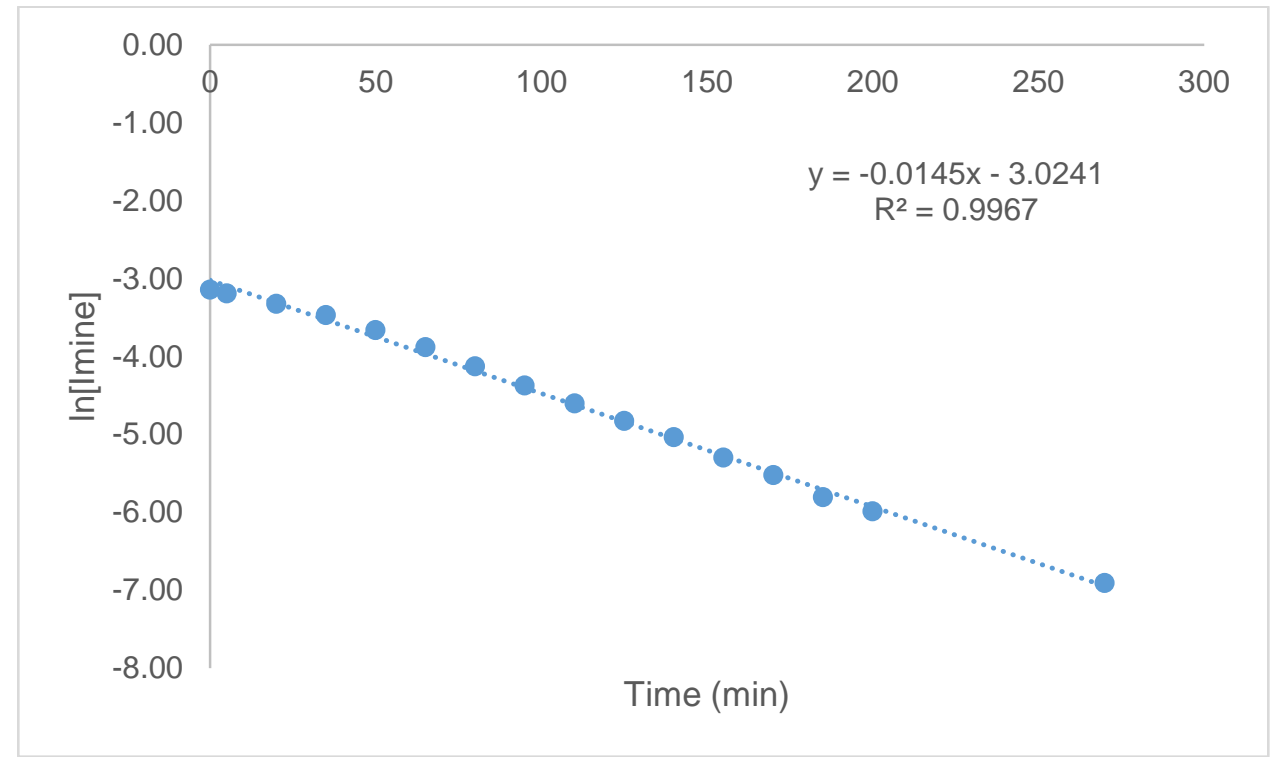

$\mathrm{CO}$ pressure $=4 \mathrm{~atm}[\mathrm{ArI}]=0.51 \mathrm{~mol} / \mathrm{L}$

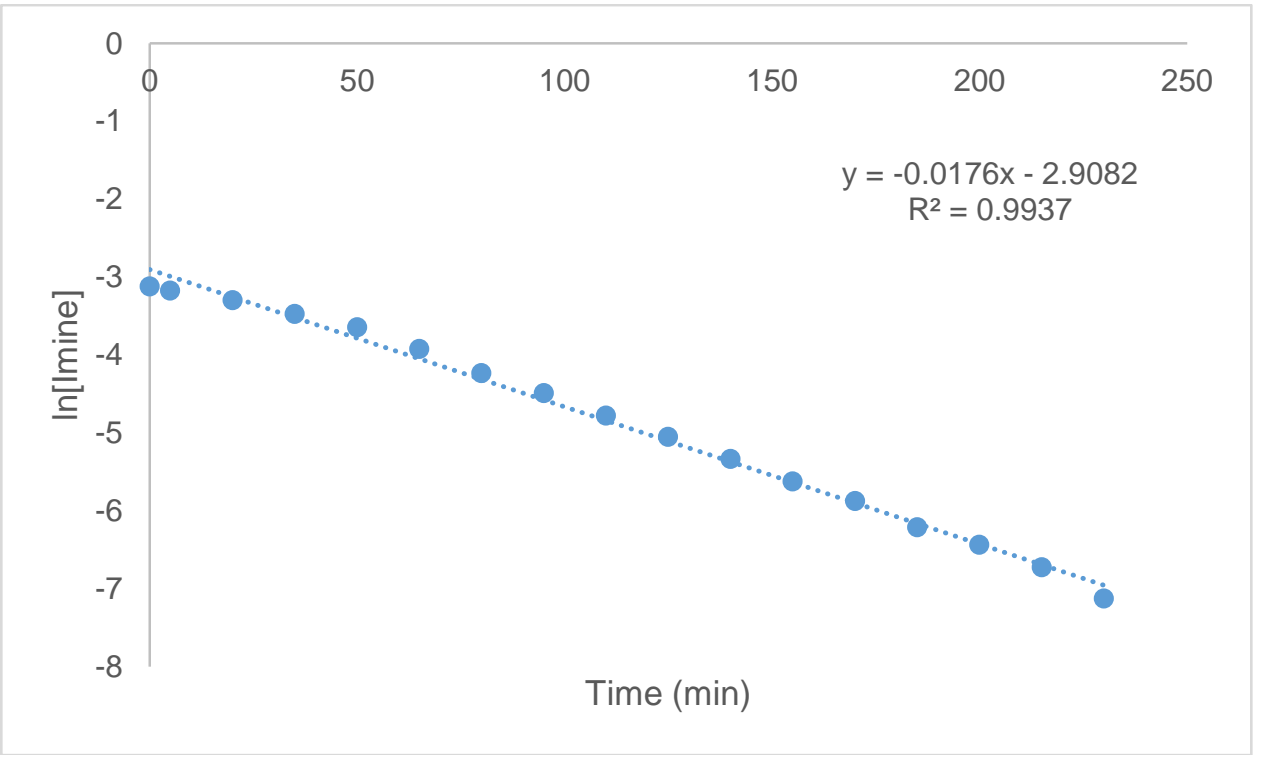


Effect of aryl iodide concentration on initial rate:

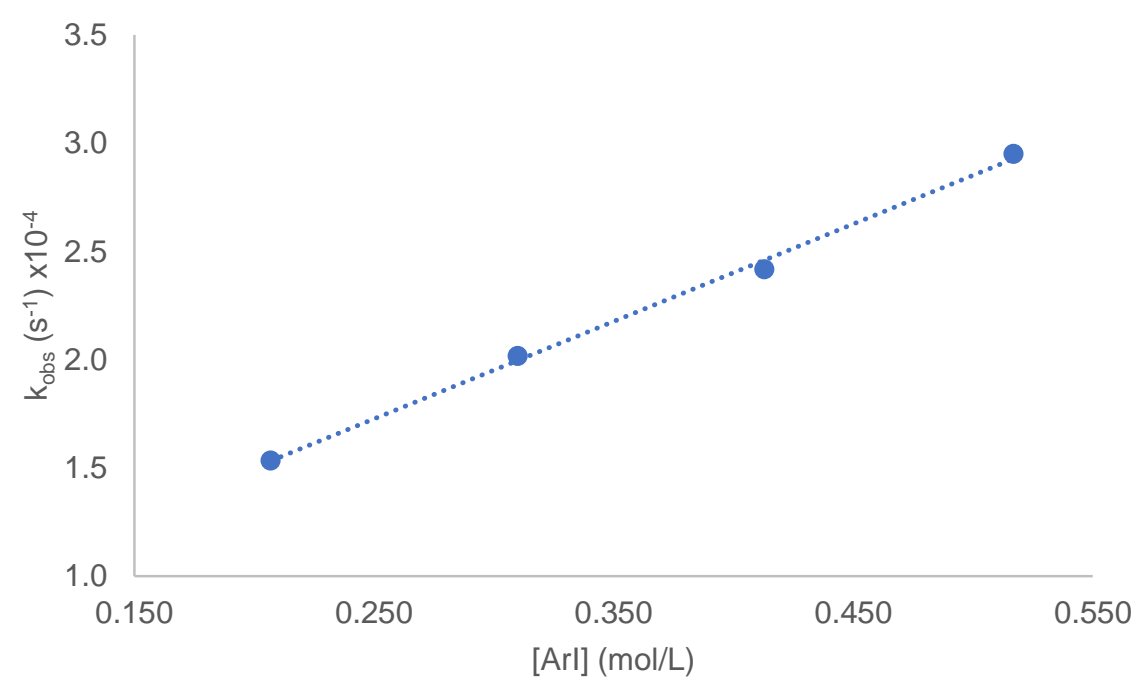

\section{Influence of Imine Concentration on Initial Rate}

Since imine is the limiting reagent in the reaction, its effect on the reaction rate was determined by examining initial rates at different imine concentrations.

$[\text { Imine }]_{0}=0.01 \mathrm{~mol} / \mathrm{L}$

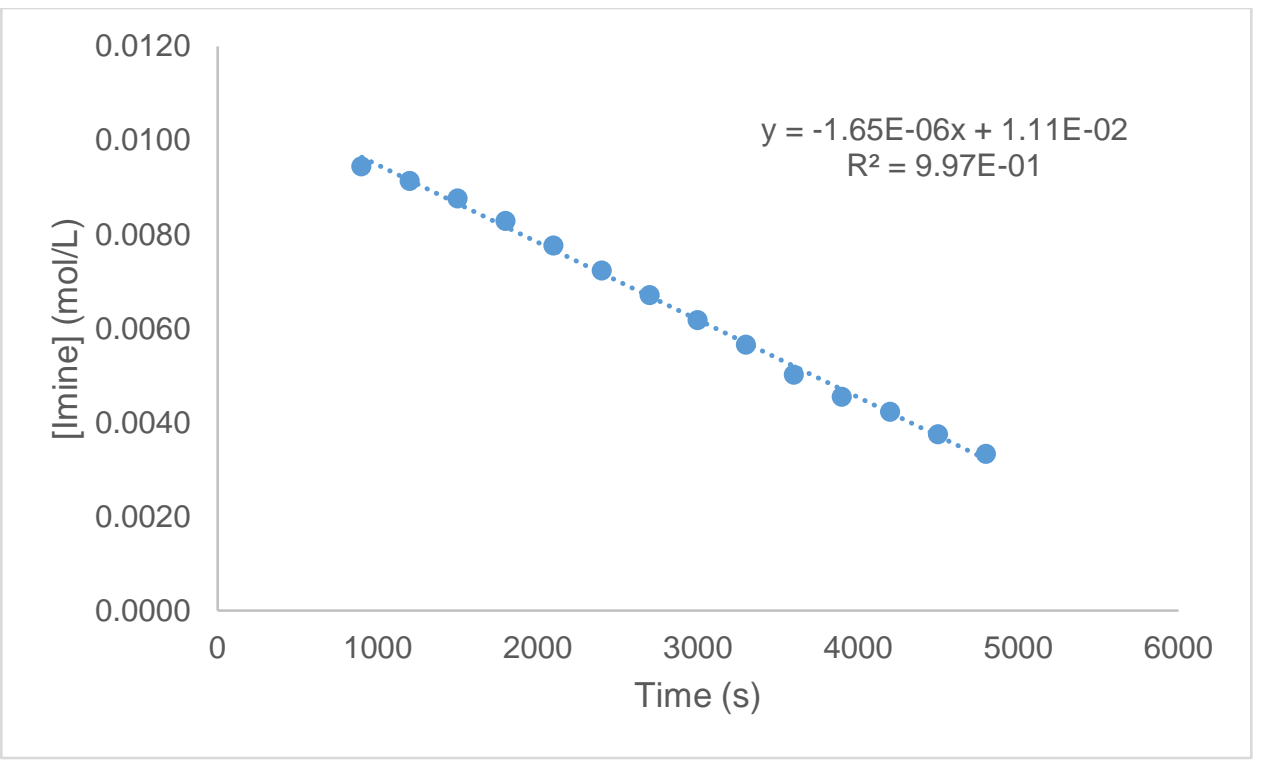


$[\text { Imine }]_{0}=0.02 \mathrm{~mol} / \mathrm{L}$

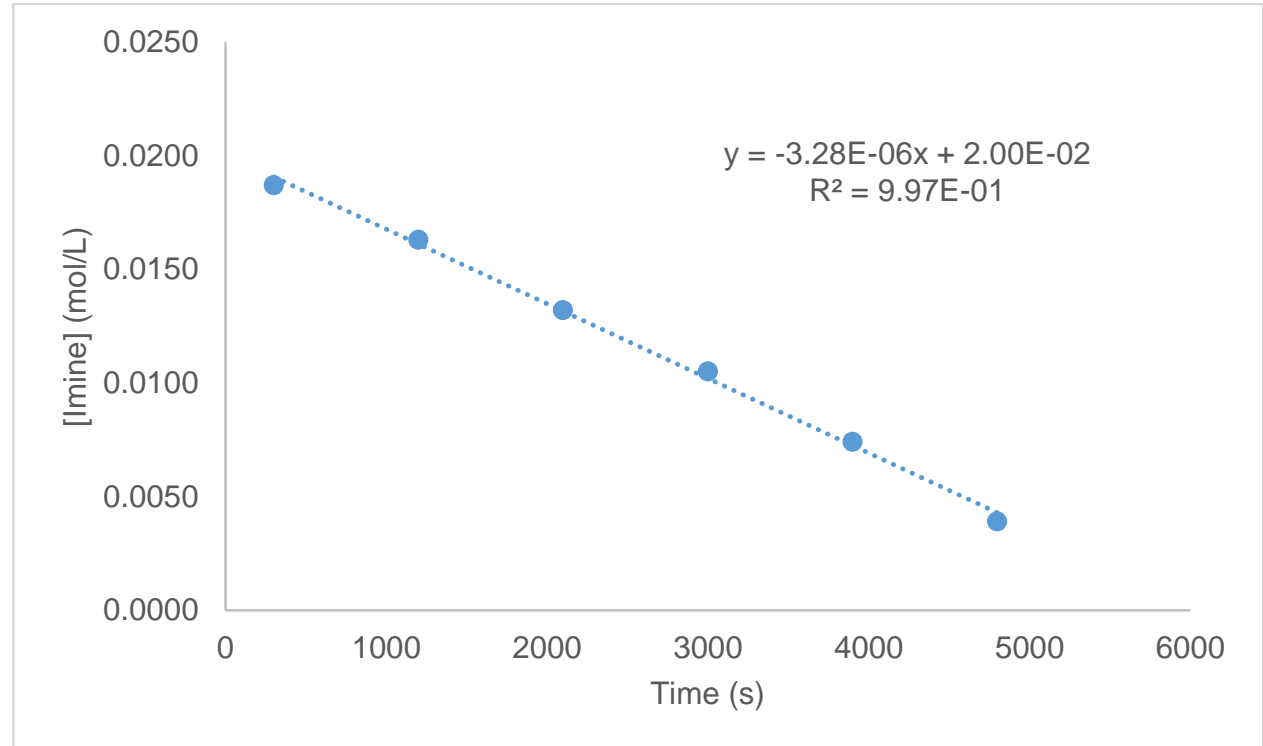

$[\text { Imine }]_{0}=0.03 \mathrm{~mol} / \mathrm{L}$

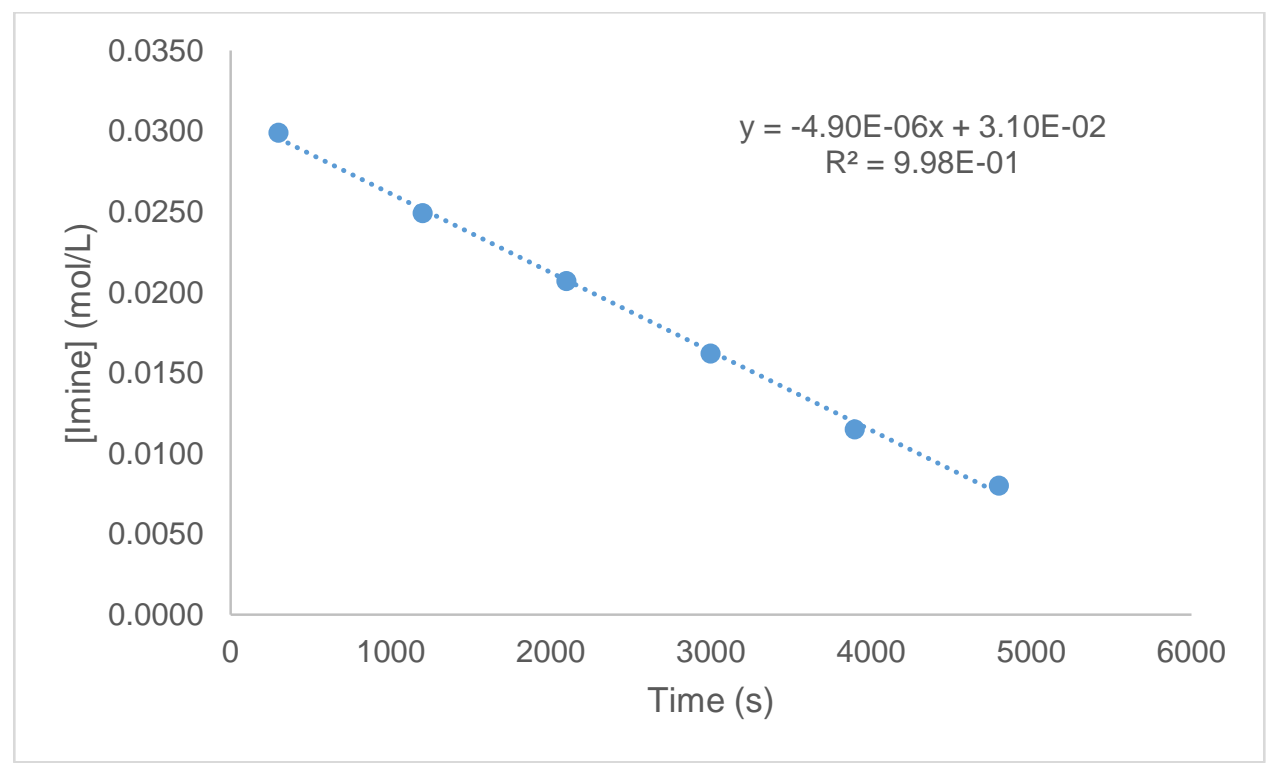


$[\text { Imine }]_{0}=0.04 \mathrm{~mol} / \mathrm{L}$

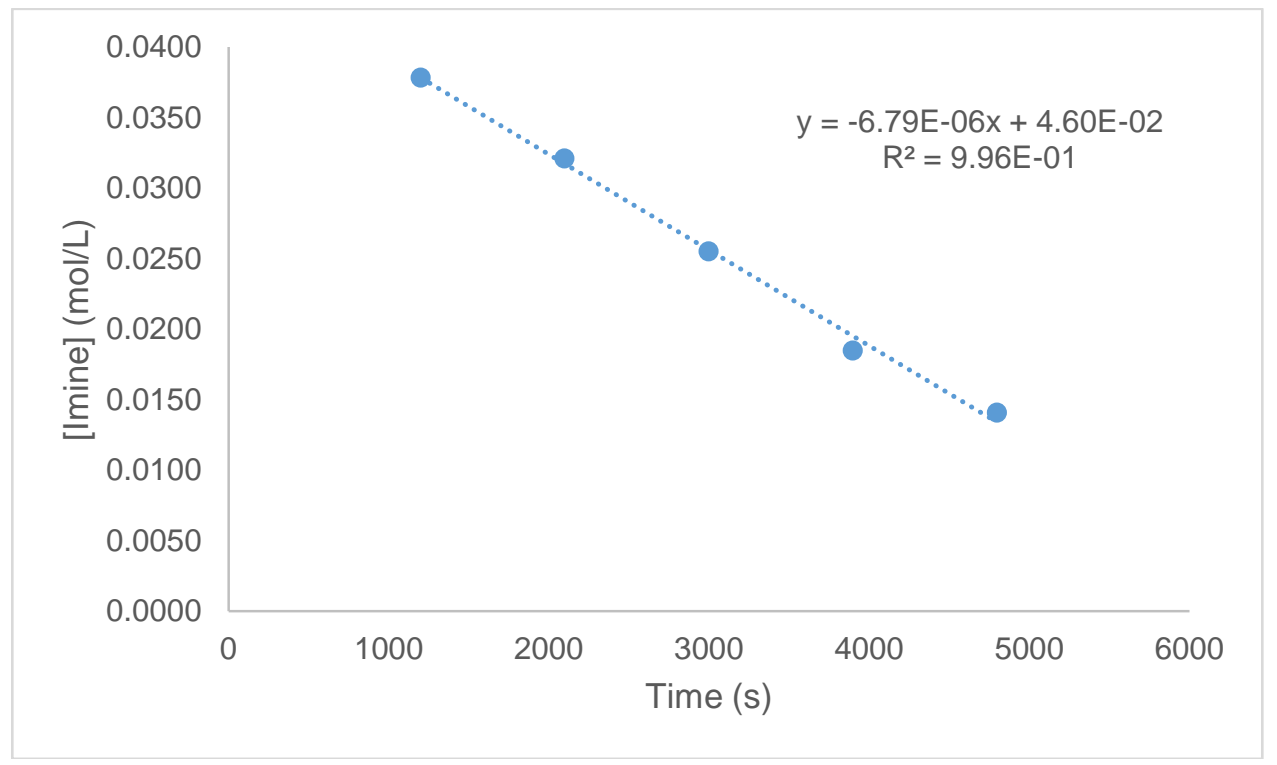

Effect of imine concentration on initial rate:

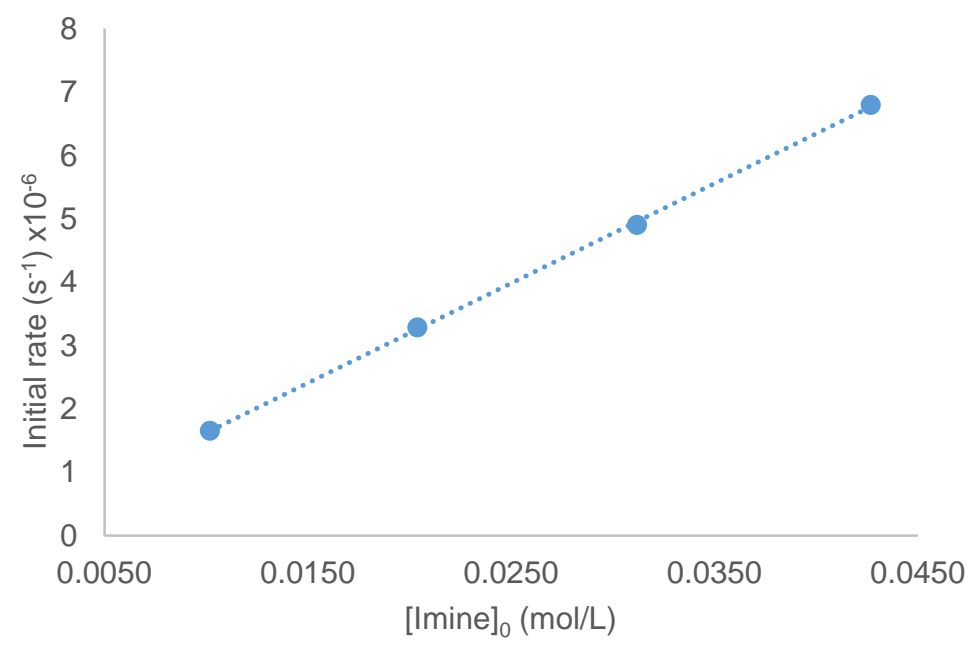




\section{Typical Procedure for the Catalytic Münchnone Formation}

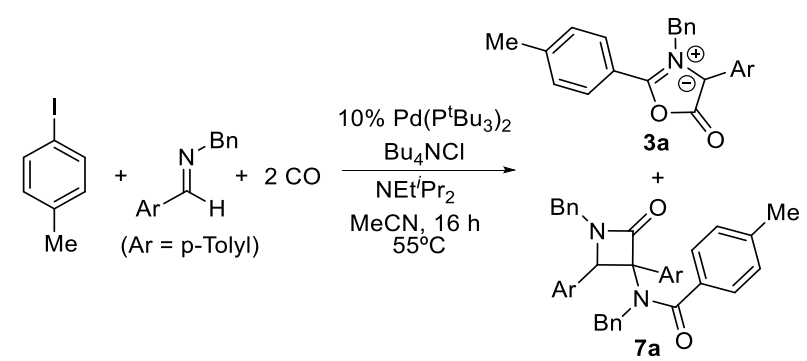

In a glovebox, $\mathrm{Pd}\left(\mathrm{P}^{t} \mathrm{Bu}_{3}\right)_{2}(13 \mathrm{mg}, 0.025 \mathrm{mmol})$ and $\mathrm{Bu}_{4} \mathrm{NCl}(69 \mathrm{mg}, 0.25 \mathrm{mmol})$ were dry-transferred into a $25 \mathrm{~mL}$ Teflon-sealed glass Schlenk bomb vessel equipped with a magnetic stir bar. $\mathrm{NEt}^{i} \operatorname{Pr}_{2}$ (49 mg, $\left.0.375 \mathrm{mmol}\right)$, 4-iodotoluene (55 mg, $\left.0.25 \mathrm{mmol}\right),(p-$ Tolyl)CH=NBn (52 mg, $0.25 \mathrm{mmol})$, and benzyl benzoate standard (26 mg, $0.125 \mathrm{mmol})$ were dissolved in $1.7 \mathrm{~mL} \mathrm{MeCN}$ and transferred into the vessel. The vessel was taken out of the glovebox, frozen, and evacuated before adding 1 atm of CO. The vessel was warmed to $55{ }^{\circ} \mathrm{C}$ with stirring for 16 hours. At the end of the reaction, $\mathrm{CO}$ was removed and the vessel was brought back into the glovebox. The solvent was evaporated in vacuo; the remaining oil was dissolved in $\mathrm{CD}_{3} \mathrm{CN}$ and the yields of Münchnone 3a $(20 \%)^{5}$ and $\beta$ lactam 7a $(32 \%)^{6}$ were calculated by ${ }^{1} \mathrm{H}$ NMR integration vs. the internal standard.

For experiments with 10 atm $\mathrm{CO}$, the above procedure was repeated in a $2 \mathrm{~mL}$ glass vial with a pierced cap. The vial was placed inside a $40 \mathrm{~mL}$ Parr steel autoclave, which was sealed, taken out of the glovebox, and charged with 10 atm $\mathrm{CO}$ using a Parr Multiwell Reactor 5000. The reactor was then submerged in a constant temperature bath at $55^{\circ} \mathrm{C}$ and stirred magnetically.

\section{Typical Procedure for Phosphine Ligand Screening}

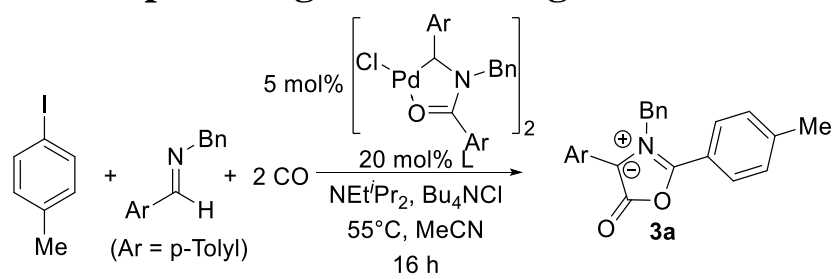

In a glovebox, $4 \mathbf{a}(6.8 \mathrm{mg}, 0.0075 \mathrm{mmol})$ and $\mathrm{Bu}_{4} \mathrm{NCl}(42 \mathrm{mg}, 0.15 \mathrm{mmol}), \mathrm{NEt}^{i} \operatorname{Pr}_{2}$ (29 mg, $0.225 \mathrm{mmol})$, 4-iodotoluene (33 mg, $0.15 \mathrm{mmol})$, ( $p$-Tolyl)CH=NBn (31 mg, 0.15 $\mathrm{mmol}), \mathrm{P}^{t} \mathrm{Bu}_{3}(6.1 \mathrm{mg} .0 .03 \mathrm{mmol})$, and benzyl benzoate standard $(16 \mathrm{mg}, 0.075 \mathrm{mmol})$ were dissolved in $1 \mathrm{~mL} \mathrm{CD} \mathrm{CD}_{3} \mathrm{CN}$ and transferred into a $25 \mathrm{~mL}$ Teflon-sealed glass Schlenk bomb vessel equipped with a magnetic stir bar. The vessel was taken out of the glovebox, charged with $4 \mathrm{~atm}$ of $\mathrm{CO}$, then heated to $55^{\circ} \mathrm{C}$ with magnetic stirring for 16 hours. The $\mathrm{CO}$ was then removed, and the vessel was brought back into the glovebox. The mixture was transferred into an NMR tube and the yield of Münchnone 3a (62\%) and $\beta$-lactam 7a (20\%) were calculated via ${ }^{1} \mathrm{H}$ NMR integrations vs the internal standard. 


\section{Typical Procedure for Pyrrole Synthesis}

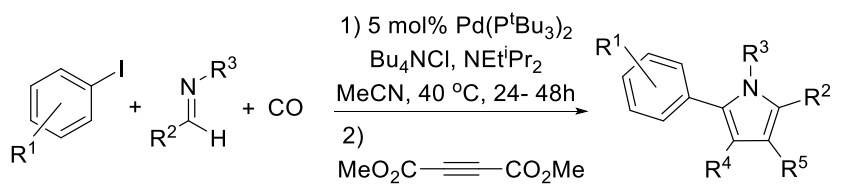

In a glovebox, $\mathrm{Pd}\left(\mathrm{P}^{\mathrm{t}} \mathrm{Bu}_{3}\right)_{2}(13 \mathrm{mg}, 0.025 \mathrm{mmol})$, and $\mathrm{Bu}_{4} \mathrm{NCl}(139 \mathrm{mg}, 0.5 \mathrm{mmol})$ were placed in a $4 \mathrm{~mL}$ vial equipped with a magnetic stir bar. (p-Tolyl)HC=NBn $(105 \mathrm{mg}$, $0.5 \mathrm{mmol}$ ), 4-iodotoluene (545 mg, $2.5 \mathrm{mmol})$, and $\mathrm{NEt}^{i} \operatorname{Pr}_{2}(97 \mathrm{mg}, 0.75 \mathrm{mmol}$ ) were dissolved in $3.3 \mathrm{~mL}$ of $\mathrm{MeCN}$ and transferred into the $4 \mathrm{~mL}$ glass vial. (For the synthesis of pyrrole 8e, a mixture of MeCN/THF (2:1) was used as the solvent due to the limited solubility of the aryl iodide in pure $\mathrm{MeCN}$.) The vial was closed with a pierced plastic cap, placed inside a Parr steel autoclave, sealed, and taken out of the glovebox. The reactor was charged with 10 atm CO using a Parr Multiwell Reactor 5000. The autoclave was then submerged in a constant temperature bath at $40^{\circ} \mathrm{C}$ and magnetically stirred. After $16 \mathrm{~h}, \mathrm{CO}$ was removed, and the vessel back into the glovebox. The reactor was opened and dimethylacetelynedicarboxylate (DMAD) $(107 \mathrm{mg}, 0.75 \mathrm{mmol})$ was added. The mixture was allowed to stir for 15 minutes and then the vessel was taken out of the glovebox. The pyrrole product was isolated by flash chromatography on silica gel (230-400 mesh) with hexanes-ethyl acetate 4:1 (8a-v,y,z,aa) or hexanes-ethyl acetate 9:1 (8w, $\mathbf{x}, \mathbf{a b}, \mathbf{a f})$. The fractions containing pyrrole were evaporated under reduced pressure and solvent traces were removed in vacuo. Pyrrole 8a was obtained in $84 \%$ (191 $\mathrm{mg}, 0.42 \mathrm{mmol}$ ) as a pale yellow solid.

For the synthesis of $\mathbf{8 j}$, the reaction was carried out in $12 \mathrm{~mL} \mathrm{MeCN}$, due to the insolubility of the heteroaryl iodide. The mixture of reagents was placed inside a $20 \mathrm{~mL}$ glass vessel equipped with a stir bar. The vessel was placed inside a Parr steel autoclave and the rest of the procedure was followed as described above. For pyrrole 8r,t,y the reaction was carried out at $60^{\circ} \mathrm{C}$, for $48 \mathrm{~h}$, with $10 \mathrm{~mol} \%$ catalyst $(26 \mathrm{mg}, 0.05 \mathrm{mmol})$. The Münchnone for 8s,af was synthesized at room temperature for $5 \mathrm{~h}$. After the synthesis of Münchnone, the vessel was opened and the dipolarophiles were added in the following manner:

Alkyne dipolarophiles were added directly into the reaction mixture $(0.75 \mathrm{mmol})$ and the solution was allowed to stir at room temperature for different times: 15 minutes for DMAD (8a-u) and dibenzoylacetylene (8v) derived pyrroles, 24 hours for $\mathbf{8 w}, 5$ hours for $\mathbf{8 x}$. For pyrroles derived from methyl or ethyl phenylpropiolate $(\mathbf{8 y}, \mathbf{z}, \mathbf{a a})$, the alkyne was added in situ at the beginning of the reaction $(0.75 \mathrm{mmol})$.

For alkene dipolarophiles, additional $\mathrm{NEt}^{i} \mathrm{Pr}_{2}(97 \mathrm{mg}, 0.75 \mathrm{mmol})$ was first added followed by the dipolarophile $(1.0 \mathrm{mmol})$. The reaction mixture was stirred for 3 hours affording pyrroles (8ab,ac,ae,af). Pyrrole 8ad was obtained by first evaporating the crude Münchnone mixture in vасио. The resulting oil was redissolved in THF and diisopropylcarbodiimide (DIPC) $(189 \mathrm{mg}, 1.5 \mathrm{mmol})$ was added to the mixture followed by trans- $\beta$-nitrostyrene $(112 \mathrm{mg}, 0.75 \mathrm{mmol})$. The reaction vessel was placed back in the Parr steel autoclave and brought out of the glove box. The reactor was heated at $55{ }^{\circ} \mathrm{C}$ for 24 hours. ${ }^{4}$ 


\section{Characterization Data on Pyrroles}

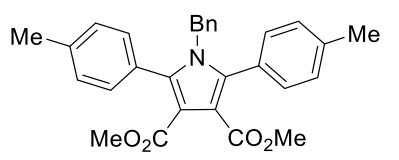

Dimethyl 1-benzyl-2,5-di-p-tolyl-1H-pyrrole-3,4-dicarboxylate (8a)

Isolated yield 84\%. Pale yellow solid. ${ }^{1} \mathrm{H}$ NMR $(500 \mathrm{MHz}$, $\left.\mathrm{CDCl}_{3}\right): \delta$ 7.18-7.11 (m, 11H), 6.59-6.57 (m, 2H), $4.91(\mathrm{~s}, 2 \mathrm{H})$, $3.68(\mathrm{~s}, 6 \mathrm{H}), 2.33(\mathrm{~s}, 6 \mathrm{H}) .{ }^{13} \mathrm{C} \mathrm{NMR}\left(126 \mathrm{MHz} \mathrm{CDCl}_{3}\right): \delta 165.5,138.5,137.4,137.2$, 130.4, 128.8, 128.3, 127.6, 127.1, 126.1, 114.6, 51.6, 48.4, 21.4. HRMS $\left(\mathrm{ESI}^{+}\right)$for $\mathrm{C}_{29} \mathrm{H}_{28} \mathrm{O}_{4} \mathrm{~N}^{+}$; calculated 454.20128, found 454.20120 (error $\mathrm{m} / \mathrm{z}=1.79 \mathrm{ppm}$ )

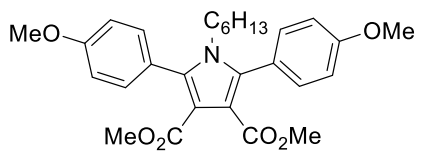

Dimethyl 1-hexyl-2,5-bis(4-methoxyphenyl)-1H-pyrrole-3,4dicarboxylate $(\mathbf{8 b})$

Isolated yield $87 \%$. Yellow oil. ${ }^{1} \mathrm{H} \mathrm{NMR}\left(500 \mathrm{MHz}, \mathrm{CDCl}_{3}\right): \delta$ $7.33(\mathrm{~d}, \mathrm{~J}=8.8 \mathrm{~Hz}, 4 \mathrm{H}), 6.97(\mathrm{~d}, \mathrm{~J}=8.8 \mathrm{~Hz}, 4 \mathrm{H}), 3.86(\mathrm{~s}, 6 \mathrm{H})$, $3.66(\mathrm{~s}, 6 \mathrm{H}), 3.68-3.65(\mathrm{~m}, 2 \mathrm{H}), 1.20-1.15(\mathrm{~m}, 2 \mathrm{H}), 1.06-0.98(\mathrm{~m}, 2 \mathrm{H}), 0.90-0.80(\mathrm{~m}, 4 \mathrm{H})$, $0.72(\mathrm{t}, \mathrm{J}=7.3 \mathrm{~Hz}, 3 \mathrm{H}) .{ }^{13} \mathrm{C} \mathrm{NMR}\left(126 \mathrm{MHz} \mathrm{CDCl}_{3}\right): \delta 165.6,159.8,136.3,131.8,123.2$, 114.1, 113.7, 55.2, 51.5, 44.8, 30.7, 30.1, 25.8, 22.1, 13.8. HRMS (ESI ${ }^{+}$) for $\mathrm{C}_{28} \mathrm{H}_{34} \mathrm{O}_{6} \mathrm{~N}^{+}$; calculated 480.23806, found 480.23775 (error $\mathrm{m} / \mathrm{z}=-0.65 \mathrm{ppm})$

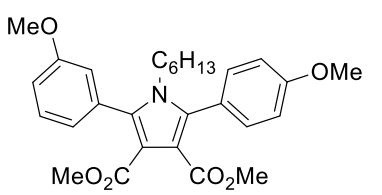

Dimethyl 1-hexyl-2-(3-methoxyphenyl)-5-(4-methoxyphenyl)1H-pyrrole-3,4-dicarboxylate (8c)

Isolated yield $81 \%$. Yellow oil. ${ }^{1} \mathrm{H}$ NMR $\left(500 \mathrm{MHz}, \mathrm{CDCl}_{3}\right): \delta$

7.37-7.32 (m, 3H), 7.00-6.95 (m, 5H), $3.86(\mathrm{~s}, 3 \mathrm{H}), 3.84(\mathrm{~s}, 3 \mathrm{H})$, 3.70-3.66 (m, 2H), $3.67(\mathrm{~s}, 3 \mathrm{H}), 3.67(\mathrm{~s}, 3 \mathrm{H}) 1.22-1.16(\mathrm{~m}, 2 \mathrm{H}), 1.06-0.98(\mathrm{~m}, 2 \mathrm{H}), 0.90-$ $0.80(\mathrm{~m}, 4 \mathrm{H}), 0.73-0.70(\mathrm{t}, \mathrm{J}=7.2 \mathrm{~Hz}, 3 \mathrm{H}) .{ }^{13} \mathrm{C} \mathrm{NMR}\left(126 \mathrm{MHz}, \mathrm{CDCl}_{3}\right): \delta 165.6,165.4$, $159.8,159.3,136.6,135.9,132.3,131.8,129.2$, 123.1, 122.9, 116.0, 114.5, 114.4, 114.0, 113.7, 55.3, 55.2, 51.6, 51.5, 44.9, 30.7, 30.2, 25.8, 22.1, 13.8. HRMS (ESI ${ }^{+}$for $\mathrm{C}_{28} \mathrm{H}_{33} \mathrm{NNaO}_{6}{ }^{+}$; calculated 502.2200, found 502.2208 (error $\mathrm{m} / \mathrm{z}=1.6 \mathrm{ppm}$ )

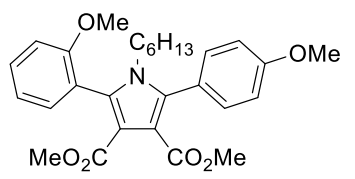

Dimethyl 1-hexyl-2-(2-methoxyphenyl)-5-(4-methoxyphenyl)-1Hpyrrole-3,4-dicarboxylate (8d)

Isolated yield $83 \%$. Yellow oil. ${ }^{1} \mathrm{H} \mathrm{NMR}\left(500 \mathrm{MHz}, \mathrm{CDCl}_{3}\right): \delta 7.43-$ $7.39(\mathrm{~m}, 1 \mathrm{H}), 7.37-7.35(\mathrm{~d}, \mathrm{~J}=8.8 \mathrm{~Hz}, 2 \mathrm{H}), 7.31-7.29(\mathrm{dd}, \mathrm{J}=7.6$, $1.8 \mathrm{~Hz}, 1 \mathrm{H}), 7.04-7.01(\mathrm{td}, \mathrm{J}=7.6,0.9 \mathrm{~Hz}, 1 \mathrm{H}), 6.98-6.95(\mathrm{~m}, 3 \mathrm{H}), 3.86(\mathrm{~s}, 3 \mathrm{H}), 3.80(\mathrm{~s}$, $3 \mathrm{H}), 3.66-3.51(\mathrm{~m}, 2 \mathrm{H}), 3.66(\mathrm{~s}, 3 \mathrm{H}), 3.63(\mathrm{~s}, 3 \mathrm{H}) 1.21-1.11(\mathrm{~m}, 2 \mathrm{H}), 1.05-0.97(\mathrm{~m}, 2 \mathrm{H})$, $0.89-0.78(\mathrm{~m}, 4 \mathrm{H}), 0.72-0.70(\mathrm{t}, \mathrm{J}=7.3 \mathrm{~Hz}, 3 \mathrm{H}) .{ }^{13} \mathrm{C} \mathrm{NMR}\left(126 \mathrm{MHz}, \mathrm{CDCl}_{3}\right): \delta 165.7$, $165.4,159.7,157.6,136.4,133.5,132.8,131.9,130.5,123.4,120.4,120.1,114.3,114.2$, 113.6, 110.9, 55.5, 55.2, 51.5, 51.3, 45.0, 30.8, 30.0, 25.8, 22.1, 13.8. HRMS (ESI ${ }^{+}$) for $\mathrm{C}_{28} \mathrm{H}_{33} \mathrm{NNaO}_{6}{ }^{+}$; calculated 502.2200, found 502.2204 (error $\mathrm{m} / \mathrm{z}=-0.9 \mathrm{ppm}$ )

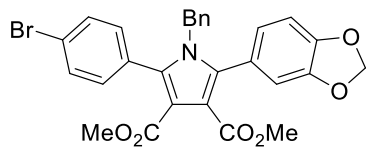

Dimethyl

2-(benzo[d][1,3]dioxol-5-yl)-1-benzyl-5-(4bromophenyl)-1H-pyrrole-3,4-dicarboxylate $(8 \mathrm{e})$

Isolated yield $82 \%$. Pale yellow solid. ${ }^{1} \mathrm{H} \mathrm{NMR}\left(500 \mathrm{MHz}, \mathrm{CDCl}_{3}\right)$ : $\delta 7.45(\mathrm{~d}, \mathrm{~J}=8.5 \mathrm{~Hz}, 2 \mathrm{H}), 7.16-7.10(\mathrm{~m}, 5 \mathrm{H}), 6.77(\mathrm{~d}, \mathrm{~J}=1.2 \mathrm{~Hz}$, 2H), 6.75 (dd, J = 1.2, 0.9, 1H), 6.60-6.58 (m, 2H), 5.98 (s, 2H), 4.89 (s, 2H), 3.72 (s, 3H), $3.67(\mathrm{~s}, 3 \mathrm{H}) .{ }^{13} \mathrm{C}$ NMR $\left(126 \mathrm{MHz}, \mathrm{CDCl}_{3}\right): \delta 165.3,165.0,148.2,147.4,136.94,136.8_{6}$, $135.7,132.1,131.3,129.5,128.5,127.4,125.9,124.6,123.6,123.2,115.1,114.8,110.9$, 
108.2, 101.3, 51.8, 51.7, 48.5. HRMS $\left(\mathrm{ESI}^{+}\right)$for $\mathrm{C}_{28} \mathrm{H}_{23} \mathrm{NO}_{6} \mathrm{Br}^{+}$; calculated 548.07033, found 548.06982 (error $\mathrm{m} / \mathrm{z}=-0.93 \mathrm{ppm})$

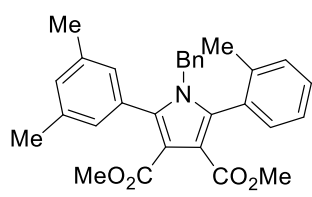

Dimethyl 1-benzyl-2-(3,5-dimethylphenyl)-5-(o-tolyl)-1H-pyrrole3,4-dicarboxylate (8f)

Isolated yield $81 \%$. Pale yellow solid. ${ }^{1} \mathrm{H}$ NMR (500 $\left.\mathrm{MHz}, \mathrm{CDCl}_{3}\right): \delta$ 7.29-7.25 (m, 1H), 7.18-7.05 (m, 6H), $6.99(\mathrm{~s}, 1 \mathrm{H}), 6.94(\mathrm{~m}, 2 \mathrm{H}), 6.52$ $(\mathrm{d}, \mathrm{J}=6.7 \mathrm{~Hz}, 2 \mathrm{H}), 4.80(\mathrm{~d}, \mathrm{~J}=15.6 \mathrm{~Hz}, 1 \mathrm{H}), 4.73(\mathrm{~d}, \mathrm{~J}=15.6 \mathrm{~Hz}$, 1H), $3.70(\mathrm{~s}, 3 \mathrm{H}), 3.62$ (s, 3H), 2.29 (s, 6H), 1.97 (s, 3H). $\left.{ }^{13} \mathrm{C} \mathrm{NMR} \mathrm{(126} \mathrm{MHz,} \mathrm{CDCl}_{3}\right): \delta$ $165.9,164.8,138.8,137.6,137.0,136.9_{7}, 136.9_{5}, 131.0,130.6,130.4_{1}, 130.3_{9}, 129.8$, 129.0, 128.4, 128.1, 127.2, 126.7, 125.3, 114.9, 114.0, 51.7, 51.3, 48.5, 21.3, 19.5. HRMS $\left(\mathrm{ESI}^{+}\right.$) for $\mathrm{C}_{30} \mathrm{H}_{30} \mathrm{NO}_{4}{ }^{+}$; calculated 468.21693, found 468.21793 (error m/z $=2.13 \mathrm{ppm}$ )

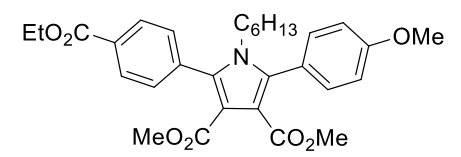

Dimethyl 2-(4-(ethoxycarbonyl)phenyl)-1-hexyl-5-(4methoxyphenyl)-1H-pyrrole-3,4-dicarboxylate (8g)

Isolated yield $83 \%$. Pale yellow oil. ${ }^{1} \mathrm{H}$ NMR $(500 \mathrm{MHz}$, $\left.\mathrm{CDCl}_{3}\right): \delta 8.13(\mathrm{~d}, \mathrm{~J}=8.5 \mathrm{~Hz}, 2 \mathrm{H}), 7.49(\mathrm{~d}, \mathrm{~J}=8.5 \mathrm{~Hz}, 2 \mathrm{H})$, $7.33(\mathrm{~d}, \mathrm{~J}=8.8 \mathrm{~Hz}, 2 \mathrm{H}), 6.98(\mathrm{~d}, \mathrm{~J}=8.8 \mathrm{~Hz}, 2 \mathrm{H}), 4.41(\mathrm{q}, \mathrm{J}=7.0 \mathrm{~Hz}, 2 \mathrm{H}), 3.86(\mathrm{~s}, 3 \mathrm{H})$, $3.67(\mathrm{~m}, 2 \mathrm{H}), 3.67(\mathrm{~s}, 3 \mathrm{H}), 3.64(\mathrm{~s}, 3 \mathrm{H}), 1.42(\mathrm{t}, \mathrm{J}=7.0 \mathrm{~Hz}, 3 \mathrm{H}), 1.18-1.12(\mathrm{~m}, 2 \mathrm{H}), 1.04-$ $0.96(\mathrm{~m}, 2 \mathrm{H}), 0.88-077(\mathrm{~m}, 4 \mathrm{H}), 0.70(\mathrm{t}, \mathrm{J}=7.3 \mathrm{~Hz}, 3 \mathrm{H}) .{ }^{13} \mathrm{C}$ NMR $\left(126 \mathrm{MHz}, \mathrm{CDCl}_{3}\right): \delta$ 166.2, 165.4, 165.2, 159.9, 137.1, 135.8, 135.1, 131.8, 130.5 $, 130.4_{9}, 129.4,122.7,114.8$, 114.6, 113.8, 61.2, 55.3, 51.6, 45.0, 30.7, 30.2, 25.7, 22.1, 14.3, 13.8. HRMS (ESI ${ }^{+}$) for $\mathrm{C}_{30} \mathrm{H}_{36} \mathrm{NO}_{7}^{+}$; calculated 522.24863, found 522.24853 (error $\mathrm{m} / \mathrm{z}=-0.18 \mathrm{ppm}$ )

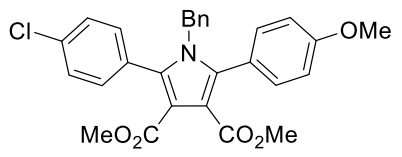

Dimethyl 1-benzyl-2-(4-chlorophenyl)-5-(4-methoxyphenyl)1H-pyrrole-3,4-dicarboxylate $(8 \mathrm{~h})$

Isolated yield $65 \%$. White solid. ${ }^{1} \mathrm{H}$ NMR $\left(500 \mathrm{MHz}, \mathrm{CDCl}_{3}\right): \delta$ $7.29(\mathrm{~d}, \mathrm{~J}=8.5 \mathrm{~Hz}, 2 \mathrm{H}), 7.22(\mathrm{~d}, \mathrm{~J}=8.8 \mathrm{~Hz}, 2 \mathrm{H}), 7.19(\mathrm{~d}, \mathrm{~J}=8.5$ $\mathrm{Hz}, 2 \mathrm{H}), 7.15-7.11(\mathrm{~m}, 3 \mathrm{H}), 6.86(\mathrm{~d}, \mathrm{~J}=8.5 \mathrm{~Hz}, 2 \mathrm{H}), 6.60-6.58(\mathrm{~m}, 2 \mathrm{H}), 4.88(\mathrm{~s}, 2 \mathrm{H}), 3.81$ $(\mathrm{s}, 3 \mathrm{H}), 3.69(\mathrm{~s}, 3 \mathrm{H}), 3.68(\mathrm{~s}, 3 \mathrm{H}) \cdot{ }^{13} \mathrm{C} \mathrm{NMR}\left(126 \mathrm{MHz}, \mathrm{CDCl}_{3}\right): \delta 165.4,165.1,159.9$, 137.3, 137.1, 135.6, 134.9, 131.9, 131.8, 129.2, 128.4 4 , 128.39, 127.4, 126.0, 122.4, 115.0, 114.9, 113.7, 55.2, 51.7, 51.6, 48.4. HRMS $\left(\mathrm{ESI}^{+}\right)$for $\mathrm{C}_{28} \mathrm{H}_{25} \mathrm{NO}_{5} \mathrm{Cl}^{+}$; calculated 490.14158, found 490.14122 (error $\mathrm{m} / \mathrm{z}=-0.73 \mathrm{ppm}$ )

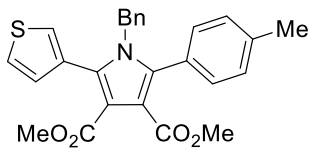

Dimethyl 1-benzyl-2-(thiophen-3-yl)-5-(p-tolyl)-1H-pyrrole-3,4dicarboxylate (8i)

Isolated yield 70\%. Light red solid. ${ }^{1} \mathrm{H}$ NMR (500 $\left.\mathrm{MHz}, \mathrm{CDCl}_{3}\right): \delta$ 7.28-7.26 (m, 1H), $7.22(\mathrm{dd}, \mathrm{J}=2.8,1.2 \mathrm{~Hz}, 1 \mathrm{H}), 7.19-7.16(\mathrm{~m}, 5 \mathrm{H})$, $7.13(\mathrm{~d}, \mathrm{~J}=7.9 \mathrm{~Hz}, 2 \mathrm{H}), 6.99(\mathrm{dd}, \mathrm{J}=4.9,1.2 \mathrm{~Hz}, 1 \mathrm{H}), 6.68(\mathrm{~m}, 2 \mathrm{H}), 4.93(\mathrm{~s}, 2 \mathrm{H}), 3.72(\mathrm{~s}$, $3 \mathrm{H}), 3.68$ (s, 3H), 2.35 (s, 3H). ${ }^{13} \mathrm{C}$ NMR (126 MHz, $\left.\mathrm{CDCl}_{3}\right): \delta 165.6,165.2,138.7,137.7$, 137.5, 131.4, 130.4, 130.2, 129.2, 128.9, 128.5, 127.5, 127.3, 126.5, 125.9, 125.1, 115.5, 114.5, 51.7, 51.6, 48.5, 21.4. HRMS $\left(\mathrm{ESI}^{+}\right)$for $\mathrm{C}_{26} \mathrm{H}_{23} \mathrm{NNaO}_{4} \mathrm{~S}^{+}$; calculated 468.1240, found 468.1232 (error $\mathrm{m} / \mathrm{z}=1.7 \mathrm{ppm}$ ) 


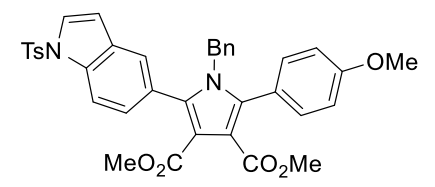

Dimethyl 1-benzyl-2-(4-methoxyphenyl)-5-(1-tosyl-1H-indol5-yl)-1H-pyrrole-3,4-dicarboxylate $(8 \mathbf{j})$

Isolated yield $90 \%$. Pale yellow solid. ${ }^{1} \mathrm{H}$ NMR $(500 \mathrm{MHz}$, $\left.\mathrm{CDCl}_{3}\right) \delta 7.91(\mathrm{~d}, J=8.6 \mathrm{~Hz}, 1 \mathrm{H}), 7.78(\mathrm{~d}, J=8.3 \mathrm{~Hz}, 2 \mathrm{H}), 7.56$ $(\mathrm{d}, J=3.6 \mathrm{~Hz}, 1 \mathrm{H}), 7.42(\mathrm{~s}, 1 \mathrm{H}), 7.25(\mathrm{~d}, J=10.1 \mathrm{~Hz}, 2 \mathrm{H}), 7.20$ $(\mathrm{dd}, J=8.8,2.5 \mathrm{~Hz}, 3 \mathrm{H}), 7.08(\mathrm{t}, J=7.3 \mathrm{~Hz}, 1 \mathrm{H}), 7.01(\mathrm{t}, J=7.5 \mathrm{~Hz}, 2 \mathrm{H}), 6.85(\mathrm{~d}, J=8.6$ $\mathrm{Hz}, 2 \mathrm{H}), 6.58(\mathrm{~d}, J=3.6 \mathrm{~Hz}, 1 \mathrm{H}), 6.48(\mathrm{~d}, J=7.5 \mathrm{~Hz}, 2 \mathrm{H}), 4.85(\mathrm{~s}, 2 \mathrm{H}), 3.80(\mathrm{~s}, 3 \mathrm{H}), 3.67$ (s, 3H), $3.60(\mathrm{~s}, 3 \mathrm{H}), 2.36(\mathrm{~s}, 3 \mathrm{H}) .{ }^{13} \mathrm{C}$ NMR $\left(126 \mathrm{MHz}, \mathrm{CDCl}_{3}\right) \delta 165.6,165.5_{7}, 160.0$, 145.2, 137.3, 137.2, 136.9, 135.4, 134.8, 132.0, 130.5, 130.1, 128.3, 127.3, 127.1, 127.0, 127.0, 126.2, 125.8, 123.9, 122.8, 114.9, 114.7, 113.7, 113.2, 109.1, 55.3, 51.7, 51.68, 48.6, 21.7. HRMS (ESI ${ }^{+}$) for $\mathrm{C}_{37} \mathrm{H}_{33} \mathrm{~N}_{2} \mathrm{O}_{7} \mathrm{~S}^{+}$; calculated 649.20030, found 649.19998 (error $\mathrm{m} / \mathrm{z}=$ $-0.49) \mathrm{ppm})$.

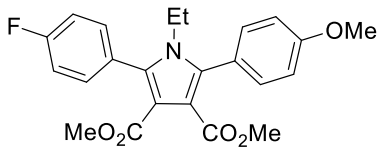

Dimethyl 1-ethyl-2-(4-fluorophenyl)-5-(4-methoxyphenyl)-1Hpyrrole-3,4-dicarboxylate $(8 \mathbf{k})$

Isolated yield $62 \%$. White solid. ${ }^{1} \mathrm{H}$ NMR $\left(500 \mathrm{MHz}, \mathrm{CDCl}_{3}\right): \delta$ $7.4(\mathrm{dd}, \mathrm{J}=8.8,5.5 \mathrm{~Hz}, 2 \mathrm{H}), 7.34(\mathrm{~d}, \mathrm{~J}=8.5 \mathrm{~Hz}, 2 \mathrm{H}), 7.15(\mathrm{t}, \mathrm{J}=$ $8.5 \mathrm{~Hz}, 2 \mathrm{H}), 6.98(\mathrm{~d}, \mathrm{~J}=8.8 \mathrm{~Hz}, 2 \mathrm{H}), 3.87(\mathrm{~s}, 3 \mathrm{H}), 3.70(\mathrm{q}, \mathrm{J}=7.0,2 \mathrm{H}), 3.67(\mathrm{~s}, 3 \mathrm{H}), 3.66$ $(\mathrm{s}, 3 \mathrm{H}), 0.84(\mathrm{t}, \mathrm{J}=7.0 \mathrm{~Hz}, 3 \mathrm{H}) .{ }^{13} \mathrm{C}$ NMR $\left(126 \mathrm{MHz}, \mathrm{CDCl}_{3}\right): \delta 165.5,165.3,163.9(\mathrm{~d}, \mathrm{~J}=$ $248.1 \mathrm{~Hz}), 159.9,136.2,135.0,132.4(\mathrm{~d}, \mathrm{~J}=8.2 \mathrm{~Hz}), 131.8,127.0$ (d, J = 3.7 Hz), 122.8, $115.5,115.3,114.5_{4}, 114.4_{7}, 113.8,55.3,51.6,51.5,39.8,16.1$. HRMS $\left(\mathrm{ESI}^{+}\right)$for $\mathrm{C}_{23} \mathrm{H}_{23} \mathrm{NO}_{5} \mathrm{~F}^{+}$; calculated 412.15548 , found 412.15598 (error $\mathrm{m} / \mathrm{z}=1.23 \mathrm{ppm}$ )

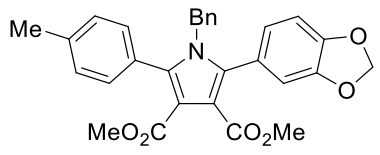

Dimethyl 2-(benzo[d][1,3]dioxol-5-yl)-1-benzyl-5-(p-tolyl)-1Hpyrrole-3,4-dicarboxylate (81)

Isolated yield $83 \%$. White solid. ${ }^{1} \mathrm{H}$ NMR $\left(500 \mathrm{MHz}, \mathrm{CDCl}_{3}\right)$ : $\delta$ $7.17(\mathrm{~d}, \mathrm{~J}=8.2 \mathrm{~Hz}, 2 \mathrm{H}), 7.14-7.12(\mathrm{~m}, 5 \mathrm{H}), 6.77-6.72(\mathrm{~m}, 3 \mathrm{H})$, 6.61-6.59 (m, 2H), $5.97(\mathrm{~s}, 2 \mathrm{H}), 4.91(\mathrm{~s}, 2 \mathrm{H}), 3.71(\mathrm{~s}, 3 \mathrm{H}), 3.68(\mathrm{~s}, 3 \mathrm{H}), 2.35(\mathrm{~s}, 3 \mathrm{H}) .{ }^{13} \mathrm{C}$ NMR $\left(126 \mathrm{MHz}, \mathrm{CDCl}_{3}\right): \delta 165.4_{3}, 165.4_{1}, 148.0,147.3,138.6,137.3,137.2,136.5,130.4$, $128.9,128.3,127.5,127.2,126.1,124.6,124.0,114.8,114.5,111.0,108.1,101.2,51.7$, 51.6, 48.4, 21.4. HRMS $\left(\mathrm{ESI}^{+}\right)$for $\mathrm{C}_{29} \mathrm{H}_{25} \mathrm{NNaO}_{6}{ }^{+}$; calculated 506.1574, found 506.1587 (error $\mathrm{m} / \mathrm{z}=2.5 \mathrm{ppm})$

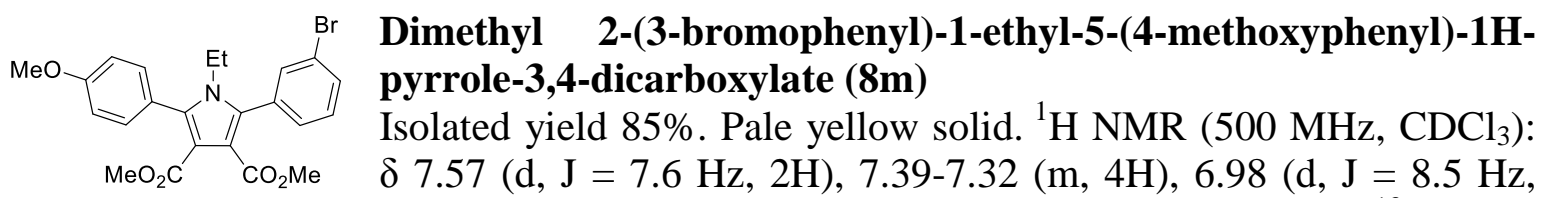
2H), $3.86(\mathrm{~s}, 3 \mathrm{H}), 3.72(\mathrm{q}, \mathrm{J}=7.0 \mathrm{~Hz}, 2 \mathrm{H}), 3.67(\mathrm{~s}, 6 \mathrm{H}), 0.85(\mathrm{t}, \mathrm{J}=7.0 \mathrm{~Hz}, 3 \mathrm{H}) .{ }^{13} \mathrm{C}$ NMR $\left(126 \mathrm{MHz}, \mathrm{CDCl}_{3}\right): \delta 165.4,165.1,159.9,136.5,134.3,133.3,133.1,131.8_{3}, 131.7_{6}, 129.8$, 129.3, 122.7, 122.2, 114.8, 114.6, 113.8, 113.5, 55.3, 51.6, 39.9, 16.1. HRMS (ESI ${ }^{+}$) for $\mathrm{C}_{23} \mathrm{H}_{23} \mathrm{NO}_{5} \mathrm{Br}^{+}$; calculated 472.07541, found 472.07502 (error $\mathrm{m} / \mathrm{z}=-0.84 \mathrm{ppm}$ ) 


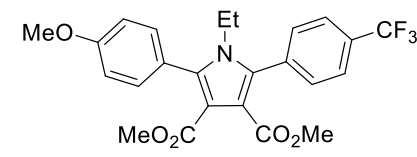

Dimethyl 1-ethyl-2-(4-methoxyphenyl)-5-(4-(trifluoromethyl) phenyl)-1H-pyrrole-3,4-dicarboxylate (8n)

Isolated yield $71 \%$. White solid. ${ }^{1} \mathrm{H}$ NMR $\left(500 \mathrm{MHz}, \mathrm{CDCl}_{3}\right): \delta$ $7.72(\mathrm{~d}, \mathrm{~J}=8.2 \mathrm{~Hz}, 2 \mathrm{H}), 7.57(\mathrm{~d}, \mathrm{~J}=7.9 \mathrm{~Hz}, 2 \mathrm{H}), 7.35(\mathrm{~d}, \mathrm{~J}=8.8$ $\mathrm{Hz}, 2 \mathrm{H}), 6.99(\mathrm{~d}, \mathrm{~J}=8.8 \mathrm{~Hz}, 2 \mathrm{H}), 3.87(\mathrm{~s}, 3 \mathrm{H}), 3.72(\mathrm{q}, \mathrm{J}=7.3 \mathrm{~Hz}, 2 \mathrm{H}), 3.68(\mathrm{~s}, 3 \mathrm{H}), 3.66$ (s, 3H), $0.84(\mathrm{t}, \mathrm{J}=7.3 \mathrm{~Hz}, 3 \mathrm{H}) .{ }^{13} \mathrm{C}$ NMR $\left(126 \mathrm{MHz}, \mathrm{CDCl}_{3}\right): \delta 165.4,165.0,160.0,136.5$, $134.9(\mathrm{~d}, \mathrm{~J}=2.7 \mathrm{~Hz}), 134.4,131.7,130.6,127.2,125.3(\mathrm{q}, \mathrm{J}=3.7 \mathrm{~Hz}), 125.1,122.9,122.6$, $114.9(\mathrm{~d}, \mathrm{~J}=17.4 \mathrm{~Hz}), 113.9,55.3,51.7,51.6,39.9,16.1 . \mathrm{HRMS}\left(\mathrm{ESI}^{+}\right)$for $\mathrm{C}_{24} \mathrm{H}_{23} \mathrm{NO}_{5} \mathrm{~F}_{3}{ }^{+}$; calculated 462.15228 , found 462.15156 (error $\mathrm{m} / \mathrm{z}=-1.56 \mathrm{ppm}$ )

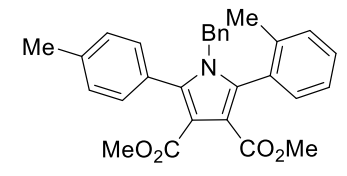

Dimethyl dicarboxylate (80)

Isolated yield $87 \%$. Pale yellow solid. ${ }^{1} \mathrm{H}$ NMR (500 MHz, $\left.\mathrm{CDCl}_{3}\right): \delta$ $7.26(\mathrm{~m}, 3 \mathrm{H}), 7.18(\mathrm{~m}, 3 \mathrm{H}), 7.10(\mathrm{~m}, 5 \mathrm{H}), 6.52(\mathrm{~d}, \mathrm{~J}=7.0 \mathrm{~Hz}, 2 \mathrm{H})$, $4.83(\mathrm{~d}, \mathrm{~J}=15.6 \mathrm{~Hz}, 1 \mathrm{H}), 3.73(\mathrm{~d}, \mathrm{~J}=15.8 \mathrm{~Hz}, 1 \mathrm{H}), 3.70(\mathrm{~s}, 3 \mathrm{H}), 3.62(\mathrm{~s}, 3 \mathrm{H}), 2.37$ (s, 3H), $1.97(\mathrm{~s}, 3 \mathrm{H}) .{ }^{13} \mathrm{C}$ NMR $\left(126 \mathrm{MHz}, \mathrm{CDCl}_{3}\right): \delta 165.8,164.9,138.7,138.6,136.9,136.8$, 136.8, 131.0, 130.5 $130.4_{7}, 129.8,129.1,129.0,128.2$, 127.6, 127.3, 126.6, 125.3, 114.9, 114.2, 51.7, 51.4, 48.3, 21.4, 19.6. HRMS $\left(\mathrm{ESI}^{+}\right)$for $\mathrm{C}_{29} \mathrm{H}_{28} \mathrm{NO}_{4}{ }^{+}$; calculated 454.20128, found 454.20040 (error $\mathrm{m} / \mathrm{z}=-1.94 \mathrm{ppm})$

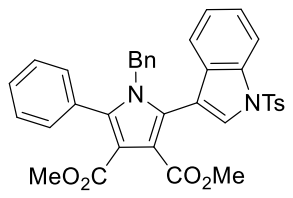

Dimethyl 1-benzyl-2-phenyl-5-(1-tosyl-1H-indol-3-yl)-1H-pyrrole3,4-dicarboxylate (8p)

Isolated yield $69 \%$. Pale yellow solid. ${ }^{1} \mathrm{H}$ NMR $\left(500 \mathrm{MHz}, \mathrm{CDCl}_{3}\right): \delta$ $7.96(\mathrm{~d}, \mathrm{~J}=7.6 \mathrm{~Hz}, 1 \mathrm{H}), 7.66(\mathrm{~d}, \mathrm{~J}=8.5 \mathrm{~Hz}, 2 \mathrm{H}), 7.52(\mathrm{~s}, 1 \mathrm{H}), 7.38$ -

$7.29(\mathrm{~m}, 7 \mathrm{H}), 7.21(\mathrm{td}, \mathrm{J}=7.9,0.9 \mathrm{~Hz}, 1 \mathrm{H}), 7.17(\mathrm{~d}, \mathrm{~J}=7.9 \mathrm{~Hz}, 2 \mathrm{H})$, 7.13-7.06 (m, 3H), 6.49 (d, J = 6.7 Hz, 2H), $4.85(\mathrm{~s}, 2 \mathrm{H}), 3.69(\mathrm{~s}, 3 \mathrm{H}), 3.50(\mathrm{~s}, 3 \mathrm{H}), 2.33(\mathrm{~s}$, $3 \mathrm{H}) .{ }^{13} \mathrm{C}$ NMR $\left(126 \mathrm{MHz}, \mathrm{CDCl}_{3}\right): \delta 164.8,145.0,138.2,137.0,135.0,134.4,130.4_{3}$, $130.42,129.9,128.9,128.4,128.2,127.8,127.5,127.4,126.8,125.8,125.0,123.7,120.2$, 116.8, 115.5, 113.7, 112.4, 51.7, 51.5, 48.9, 21.6. HRMS $\left(\mathrm{ESI}^{+}\right)$for $\mathrm{C}_{36} \mathrm{H}_{31} \mathrm{~N}_{2} \mathrm{O}_{6} \mathrm{~S}^{+}$; calculated 619.18973 , found 619.19161 (error $\mathrm{m} / \mathrm{z}=3.03 \mathrm{ppm}$ )

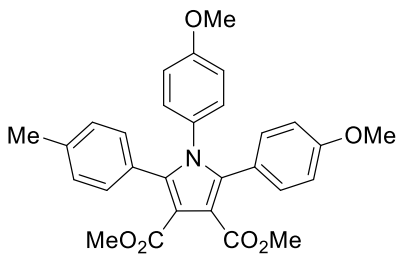

Dimethyl 1,2-bis(4-methoxyphenyl)-5-(p-tolyl)-1H-pyrrole3,4-dicarboxylate (8q)

Isolated yield $66 \%$. Pale yellow solid. ${ }^{1} \mathrm{H}$ NMR $(500 \mathrm{MHz}$, $\left.\mathrm{CDCl}_{3}\right): \delta 7.11(\mathrm{~d}, \mathrm{~J}=8.8 \mathrm{~Hz}, 2 \mathrm{H}), 7.07(\mathrm{~d}, \mathrm{~J}=7.9 \mathrm{~Hz}, 2 \mathrm{H}), 7.01$ $(\mathrm{d}, \mathrm{J}=7.9 \mathrm{~Hz}, 2 \mathrm{H}), 6.77-6.73(\mathrm{~m}, 4 \mathrm{H}), 6.61(\mathrm{~d}, \mathrm{~J}=8.8 \mathrm{~Hz}, 2 \mathrm{H})$, $3.77(\mathrm{~s}, 3 \mathrm{H}), 3.74(\mathrm{~s}, 6 \mathrm{H}), 3.71(\mathrm{~s}, 3 \mathrm{H}), 2.29(\mathrm{~s}, 3 \mathrm{H}) .{ }^{13} \mathrm{C}$ NMR $\left(126 \mathrm{MHz}, \mathrm{CDCl}_{3}\right): \delta 165.8,165.7,159.2,158.6,137.7,136.9,136.8,132.1,130.6,129.9$, $129.8,128.4,128.2,127.4,114.4,114.2,113.7,113.1,55.2,55.1,51.8,51.7,21.3$. HRMS $\left(\mathrm{ESI}^{+}\right)$for $\mathrm{C}_{29} \mathrm{H}_{28} \mathrm{NO}_{6}{ }^{+}$; calculated 486.19111, found 486.19046 (error $\mathrm{m} / \mathrm{z}=-1.34 \mathrm{ppm}$ )

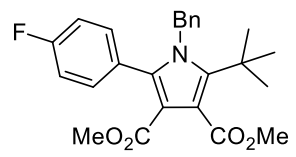

Dimethyl 1-benzyl-2-(tert-butyl)-5-(4-fluorophenyl)-1H-pyrrole-3,4dicarboxylate (8r)

Isolated yield: $40 \%$. White solid. ${ }^{1} \mathrm{H}$ NMR $\left(500 \mathrm{MHz}, \mathrm{CDCl}_{3}\right) \delta 7.22-$ $7.13(\mathrm{~m}, 3 \mathrm{H}), 6.95(\mathrm{dd}, J=8.4,5.5 \mathrm{~Hz}, 2 \mathrm{H}), 6.85(\mathrm{t}, J=8.7 \mathrm{~Hz}, 2 \mathrm{H})$, 
$6.66-6.60(\mathrm{~m}, 2 \mathrm{H}), 5.17(\mathrm{~s}, 2 \mathrm{H}), 3.91(\mathrm{~s}, 3 \mathrm{H}), 3.52(\mathrm{~s}, 3 \mathrm{H}), 1.39(\mathrm{~s}, 9 \mathrm{H}) .{ }^{13} \mathrm{C}$ NMR $(126$ $\left.\mathrm{MHz}, \mathrm{CDCl}_{3}\right) \delta 170.0,164.0,162.7(\mathrm{~d}, J=248.0 \mathrm{~Hz}), 139.0,138.1,132.4(\mathrm{~d}, J=8.3 \mathrm{~Hz})$, $128.5,127.6$ (d, $J=3.5 \mathrm{~Hz}), 127.3,125.6,115.7,114.9$ (d, $J=21.6 \mathrm{~Hz}), 112.3,52.6,51.2$, 50.1, 33.9, 30.9. HRMS (ESI ${ }^{+}$) for $\mathrm{C}_{25} \mathrm{H}_{27} \mathrm{NO}_{4} \mathrm{~F}^{+}$; calculated 424.19186, found 424.19178 (error $\mathrm{m} / \mathrm{z}=-0.20 \mathrm{ppm})$.

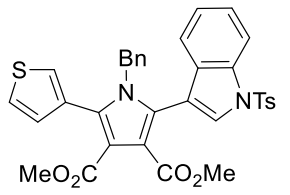

Dimethyl 1-benzyl-2-(thiophen-3-yl)-5-(1-tosyl-1H-indol-3-yl)-1Hpyrrole-3,4-dicarboxylate (8s)

Isolated yield: $51 \%$. Pale yellow solid. ${ }^{1} \mathrm{H}$ NMR $\left(500 \mathrm{MHz}, \mathrm{CDCl}_{3}\right) \delta$ $7.95(\mathrm{~d}, J=8.3 \mathrm{~Hz}, 1 \mathrm{H}), 7.62(\mathrm{~d}, J=8.4 \mathrm{~Hz}, 2 \mathrm{H}), 7.47(\mathrm{~s}, 1 \mathrm{H}), 7.33-$ $7.26(\mathrm{~m}, 4 \mathrm{H}), 7.22-7.18(\mathrm{~m}, 1 \mathrm{H}), 7.18-7.13(\mathrm{~m}, 5 \mathrm{H}), 7.02(\mathrm{dd}, J=$ 4.9, $1.2 \mathrm{~Hz}, 1 \mathrm{H}), 6.60(\mathrm{dd}, J=7.2,2.0 \mathrm{~Hz}, 2 \mathrm{H}), 4.87(\mathrm{~s}, 2 \mathrm{H}), 3.73(\mathrm{~s}, 3 \mathrm{H}), 3.47(\mathrm{~s}, 3 \mathrm{H})$, $2.32(\mathrm{~s}, 3 \mathrm{H}) .{ }^{13} \mathrm{C}$ NMR $\left(126 \mathrm{MHz}, \mathrm{CDCl}_{3}\right) \delta 165.5,164.7,145.2,137.4,135.1,134.5$, $132.7,130.6,130.0,129.2$, 128.8, 128.2, 127.7, 127.5, 126.9, 126.8, 125.7, 125.5, 125.2, $123.8,120.4,116.8,116.2,113.8,112.4,52.0,51.6,49.1,21.7 . \mathrm{HRMS}_{\left(\mathrm{ESI}^{+}\right) \text {for }}$ $\mathrm{C}_{34} \mathrm{H}_{29} \mathrm{~N}_{2} \mathrm{O}_{6} \mathrm{~S}_{2}^{+}$; calculated 625.14615, found 625.14657 (error $\mathrm{m} / \mathrm{z}=0.67 \mathrm{ppm}$ ).

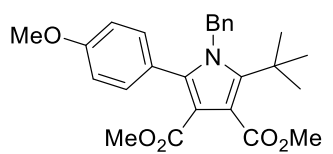

Dimethyl 1-benzyl-2-(tert-butyl)-5-(4-methoxyphenyl)-1Hpyrrole-3,4-dicarboxylate (8t)

Isolated yield $44 \%$. White solid. ${ }^{1} \mathrm{H} \mathrm{NMR}\left(500 \mathrm{MHz}, \mathrm{CDCl}_{3}\right): \delta 7.21-$ $7.16(\mathrm{~m}, 3 \mathrm{H}), 6.93(\mathrm{~d}, \mathrm{~J}=8.5 \mathrm{~Hz}, 2 \mathrm{H}), 6.71(\mathrm{~d}, \mathrm{~J}=8.8 \mathrm{~Hz}, 2 \mathrm{H}), 6.65$ $(\mathrm{d}, \mathrm{J}=8.2 \mathrm{~Hz}, 2 \mathrm{H}), 5.19(\mathrm{~s}, 2 \mathrm{H}), 3.91(\mathrm{~s}, 3 \mathrm{H}), 3.76(\mathrm{~s}, 3 \mathrm{H}), 3.55(\mathrm{~s}, 3 \mathrm{H}), 1.38(\mathrm{~s}, 9 \mathrm{H}) .{ }^{13} \mathrm{C}$ NMR (126 MHz, $\left.\mathrm{CDCl}_{3}\right): \delta 170.0,164.0,159.4,140.1,138.4,137.6,131.6,128.3,127.0$, $125.5,123.6,115.5,113.1,111.9,55.1,52.4,51.0,49.8,33.8,30.8$. HRMS $\left(\mathrm{ESI}^{+}\right)$for $\mathrm{C}_{26} \mathrm{H}_{30} \mathrm{NO}_{5}{ }^{+}$; calculated 436.21185, found 436.21175 (error $\mathrm{m} / \mathrm{z}=-0.23 \mathrm{ppm}$ ).

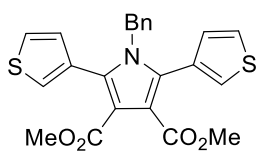

Dimethyl xylate (8u)

1-benzyl-2,5-di(thiophen-3-yl)-1H-pyrrole-3,4-dicarboIsolated yield 58\%. Pale yellow solid. ${ }^{1} \mathrm{H} \mathrm{NMR}\left(500 \mathrm{MHz}, \mathrm{CDCl}_{3}\right) \delta 7.27$ $(\mathrm{dd}, J=4.9,3.1 \mathrm{~Hz}, 2 \mathrm{H}), 7.22(\mathrm{~d}, J=3.1 \mathrm{~Hz}, 5 \mathrm{H}), 6.98(\mathrm{~d}, J=4.9 \mathrm{~Hz}$, $2 \mathrm{H}), 6.80-6.71(\mathrm{~m}, 2 \mathrm{H}), 4.95(\mathrm{~s}, 2 \mathrm{H}), 3.71(\mathrm{~s}, 6 \mathrm{H}) .{ }^{13} \mathrm{C} \mathrm{NMR}\left(126 \mathrm{MHz}, \mathrm{CDCl}_{3}\right) \delta 165.4$, $137.8,132.0,130.1,129.3,128.8,127.5,126.7,125.9,125.3,115.5,51.9,48.8$. HRMS $\left(\mathrm{ESI}^{+}\right.$) for $\mathrm{C}_{23} \mathrm{H}_{19} \mathrm{NO}_{4} \mathrm{~S}_{2} \mathrm{Na}^{+}$; calculated 460.06477 , found 460.06404 (error $\mathrm{m} / \mathrm{z}=-1.58$ ppm).

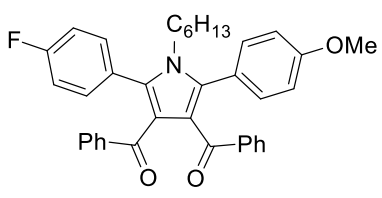

(2-(4-fluorophenyl)-1-hexyl-5-(4-methoxyphenyl)-1H-pyrrole3,4-diyl)bis(phenylmethanone) (8v)

Isolated yield $70 \%$. Pale yellow solid. ${ }^{1} \mathrm{H}$ NMR $(500 \mathrm{MHz}$, $\left.\mathrm{CDCl}_{3}\right): \delta 7.45-7.40(\mathrm{~m}, 6 \mathrm{H}), 7.36(\mathrm{~d}, \mathrm{~J}=8.5 \mathrm{~Hz}, 2 \mathrm{H}), 7.29-7.25$ $(\mathrm{m}, 2 \mathrm{H}), 7.10(\mathrm{td}, \mathrm{J}=7.9,2.3 \mathrm{~Hz}, 4 \mathrm{H}), 7.06(\mathrm{t}, \mathrm{J}=8.8 \mathrm{~Hz}, 2 \mathrm{H}), 6.88(\mathrm{~d}, \mathrm{~J}=8.8 \mathrm{~Hz}, 2 \mathrm{H})$, 3.84-3.79 (m, 2H), 3.81 (s, 3H), 1.30-1027 (m, 2H), 1.09-1.05 (m, 2H), 0.95-0.90 (m, 4H), $0.75(\mathrm{t}, \mathrm{J}=7.3 \mathrm{~Hz}, 3 \mathrm{H}) .{ }^{13} \mathrm{C}$ NMR $\left(126 \mathrm{MHz}, \mathrm{CDCl}_{3}\right): \delta 192.3,163.8(\mathrm{~d}, \mathrm{~J}=249.0 \mathrm{~Hz})$, $159.8,139.6_{2}, 139.59,137.1,135.7,132.9,132.8,132.2,131.7,131.6,128.8$ (d, J = 4.6 Hz), $127.7_{5}, 127.7_{0}, 127.0_{0}, 126.9_{7}, 123.8,123.6,122.8,115.4(\mathrm{~d}, \mathrm{~J}=21.9 \mathrm{~Hz}), 113.7,55.3$, 44.9, 30.7, 30.2, 25.9, 22.2, 13.8. HRMS $\left(\mathrm{ESI}^{+}\right)$for $\mathrm{C}_{37} \mathrm{H}_{34} \mathrm{NNaO}_{3} \mathrm{~F}^{+}$; calculated 582.2415, found 582.2415 (error $\mathrm{m} / \mathrm{z}=0.1 \mathrm{ppm})$. 


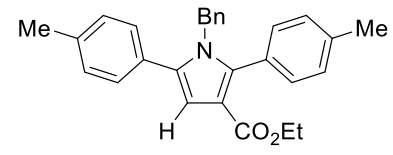

Ethyl 1-benzyl-2,5-di-p-tolyl-1H-pyrrole-3-carboxylate (8w)

Isolated yield $68 \%$. White solid. ${ }^{1} \mathrm{H}$ NMR $\left(500 \mathrm{MHz}, \mathrm{CDCl}_{3}\right): \delta$ $7.25(\mathrm{~d}, \mathrm{~J}=7.9 \mathrm{~Hz}, 2 \mathrm{H}), 7.19-7.13(\mathrm{~m}, 9 \mathrm{H}), 6.80$ (s, 1H), 6.71 (d, J $=8.2 \mathrm{~Hz}, 1 \mathrm{H}), 6.68-6.66(\mathrm{~m}, 2 \mathrm{H}), 5.06(\mathrm{~s}, 2 \mathrm{H}), 4.17(\mathrm{q}, \mathrm{J}=7.0 \mathrm{~Hz}$, 2H), $2.37(\mathrm{~s}, 3 \mathrm{H}), 2.36(\mathrm{~s}, 3 \mathrm{H}), 1.19(\mathrm{t}, \mathrm{J}=7.0 \mathrm{~Hz}, 3 \mathrm{H}) .{ }^{13} \mathrm{C} \mathrm{NMR}\left(126 \mathrm{MHz}, \mathrm{CDCl}_{3}\right): \delta$ $164.8,140.0,138.4,138.0,137.5,135.0,130.6,129.8,129.2,129.1,129.0,128.6,128.3$, 127.0, 125.9, 114.0, 110.5, 59.4, 48.4, 21.4, 21.2, 14.3. HRMS (ESI $)$ for $\mathrm{C}_{28} \mathrm{H}_{28} \mathrm{NO}_{2}{ }^{+}$; calculated 410.21146, found 410.21046 (error $\mathrm{m} / \mathrm{z}=-2.42 \mathrm{ppm})$.

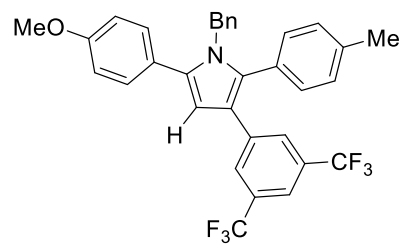

1-benzyl-3-(3,5-bis(trifluoromethyl)phenyl)-5-(4-methoxy phenyl)-2-(p-tolyl)-1H-pyrrole (8x)

Isolated yield $60 \%$. Red/orange solid. ${ }^{1} \mathrm{H}$ NMR $(500 \mathrm{MHz}$, $\left.\mathrm{CDCl}_{3}\right): \delta 7.60(\mathrm{~s}, 2 \mathrm{H}), 7.54(\mathrm{~s}, 1 \mathrm{H}), 7.32(\mathrm{~d}, \mathrm{~J}=8.8 \mathrm{~Hz}, 2 \mathrm{H})$, 7.19-7.15 (m, 3H), $7.13(\mathrm{~d}, \mathrm{~J}=7.9 \mathrm{~Hz}, 2 \mathrm{H}) 7.08(\mathrm{~d}, \mathrm{~J}=7.9,2 \mathrm{H})$, $6.98(\mathrm{~d}, \mathrm{~J}=8.8 \mathrm{~Hz}, 2 \mathrm{H}), 6.72(\mathrm{dd}, \mathrm{J}=7.8,1.7 \mathrm{~Hz}, 2 \mathrm{H}), 6.57(\mathrm{~s}$, $1 \mathrm{H}), 5.10(\mathrm{~s}, 2 \mathrm{H}), 3.83(\mathrm{~s}, 3 \mathrm{H}), 2.36(\mathrm{~s}, 3 \mathrm{H}) .{ }^{13} \mathrm{C} \mathrm{NMR}\left(126 \mathrm{MHz}, \mathrm{CDCl}_{3}\right): \delta 159.1,138.8$, $138.5,138.4,135.7,133.1,132.3,131.4,131.1,130.9$, 130.8, 130.6, 130.5, 129.5, 129.2, $129.0,128.9,128.3,127.0,126.9_{5}, 126.9_{2}, 126.7,125.9,125.3,124.6,122.4,120.2,120.1$, $118.1_{4}, 118.1_{1}, 118.0_{8}, 118.0_{5}, 114.3,113.9,108.1,55.3,48.4,21.2$. HRMS (ESI ${ }^{+}$) for $\mathrm{C}_{33} \mathrm{H}_{25} \mathrm{NOF}_{6}^{+}$; calculated 565.18349, found 565.18434 (error $\mathrm{m} / \mathrm{z}=1.5 \mathrm{ppm}$ ).

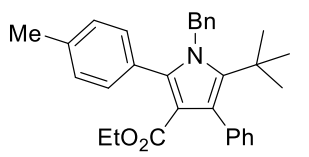

Ethyl 1-benzyl-5-(tert-butyl)-4-phenyl-2-(p-tolyl)-1H-pyrrole-3carboxylate (8y)

Isolated yield $60 \%$. White solid. ${ }^{1} \mathrm{H}$ NMR (500 MHz, Chloroform- $d$ ) $\delta$ $7.35(\mathrm{~d}, J=6.9 \mathrm{~Hz}, 2 \mathrm{H}), 7.29(\mathrm{q}, J=8.5,7.4 \mathrm{~Hz}, 3 \mathrm{H}), 7.21(\mathrm{t}, J=7.3$ $\mathrm{Hz}, 2 \mathrm{H}), 7.18-7.13(\mathrm{~m}, 1 \mathrm{H}), 7.01(\mathrm{~s}, 4 \mathrm{H}), 6.68(\mathrm{~d}, J=7.4 \mathrm{~Hz}, 2 \mathrm{H}), 5.29(\mathrm{~s}, 2 \mathrm{H}), 3.73$ (q, $J$ $=7.1 \mathrm{~Hz}, 2 \mathrm{H}), 2.29(\mathrm{~s}, 3 \mathrm{H}), 1.15(\mathrm{~s}, 9 \mathrm{H}), 0.63(\mathrm{t}, J=7.1 \mathrm{~Hz}, 3 \mathrm{H}) .{ }^{13} \mathrm{C} \mathrm{NMR}(126 \mathrm{MHz}$, $\left.\mathrm{CDCl}_{3}\right) \delta 165.3,139.7,139.7,137.6,137.0,131.5,130.5,129.8,128.5,128.3,127.0,126.8$, 126.2, 125.6, 123.5, 115.2, 59.1, 50.2, 34.4, 32.9, 21.4, 13.5. HRMS $\left(\mathrm{ESI}^{+}\right)$for $\mathrm{C}_{31} \mathrm{H}_{34} \mathrm{NO}_{2}{ }^{+}$; calculated 452.25841, found 452.25838 (error $\mathrm{m} / \mathrm{z}=-0.06 \mathrm{ppm}$ ).

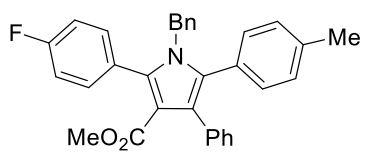

Methyl 1-benzyl-2-(4-fluorophenyl)-4-phenyl-5-(p-tolyl)-1Hpyrrole-3-carboxylate $(\mathbf{8 z})$

Isolated yield $70 \%$. Pale yellow solid. ${ }^{1} \mathrm{H} \mathrm{NMR}\left(500 \mathrm{MHz}, \mathrm{CDCl}_{3}\right)$ : $\delta$ 7.30-7.27 (m, 2H), 7.24-7.19 (m, 4H), 7.18-7.14 (m, 4H), 7.04$6.99(\mathrm{~m}, 6 \mathrm{H}), 6.66-6.64(\mathrm{~m}, 2 \mathrm{H}), 4.94(\mathrm{~s}, 2 \mathrm{H}), 3.45(\mathrm{~s}, 3 \mathrm{H}), 2.28(\mathrm{~s}, 3 \mathrm{H}) .{ }^{13} \mathrm{C}$ NMR $(126$ $\left.\mathrm{MHz} \mathrm{CDCl}_{3}\right): \delta 165.6,163.7(\mathrm{~d}, \mathrm{~J}=248.1 \mathrm{~Hz}), 138.1,137.6,137.5,135.2,133.2,132.6(\mathrm{~d}$, $\mathrm{J}=8.2 \mathrm{~Hz}), 131.2,130.6,128.9,128.4,128.3,128.2,127.2,127.1,126.0$, 125.9, 124.3, $115.0(\mathrm{~d}, \mathrm{~J}=22.0 \mathrm{~Hz}), 113.4,50.6,48.5,21.2$. HRMS $\left(\mathrm{ESI}^{+}\right)$for $\mathrm{C}_{32} \mathrm{H}_{27} \mathrm{NO}_{2} \mathrm{~F}^{+}$; calculated 476.20203, found 476.20121 (error $\mathrm{m} / \mathrm{z}=-1.73 \mathrm{ppm}$ ).

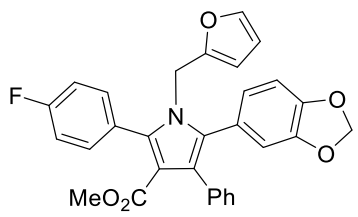

Methyl 5-(benzo[d][1,3]dioxol-5-yl)-2-(4-fluorophenyl)-1-(furan2-ylmethyl)-4-phenyl-1H-pyrrole-3-carboxylate (8aa)

Isolated yield $64 \%$. White solid. ${ }^{1} \mathrm{H}$ NMR $\left(500 \mathrm{MHz}, \mathrm{CDCl}_{3}\right): \delta$ $7.38(\mathrm{dd}, \mathrm{J}=8.5,5.2 \mathrm{~Hz}, 2 \mathrm{H}), 7.24-7.15(\mathrm{~m}, 6 \mathrm{H}), 7.11(\mathrm{t}, \mathrm{J}=8.8$ $\mathrm{Hz}, 2 \mathrm{H}), 6.71(\mathrm{~d}, \mathrm{~J}=8.2 \mathrm{~Hz}, 1 \mathrm{H}), 6.67(\mathrm{dd}, \mathrm{J}=5.2,1.5 \mathrm{~Hz}, 2 \mathrm{H})$ $6.16(\mathrm{dd}, \mathrm{J}=3.2,1.9 \mathrm{~Hz}, 1 \mathrm{H}), 6.95(\mathrm{~s}, 2 \mathrm{H}), 5.57(\mathrm{dd}, \mathrm{J}=3.1,0.7 \mathrm{~Hz}, 1 \mathrm{H}), 4.83(\mathrm{~s}, 2 \mathrm{H}), 3.43$ 
(s, 3H). ${ }^{13} \mathrm{C} \mathrm{NMR}\left(126 \mathrm{MHz}, \mathrm{CDCl}_{3}\right): \delta 165.5,163.8(\mathrm{~d}, \mathrm{~J}=248.1 \mathrm{~Hz}), 150.1,147.4,147.3$, 142.0, 137.2, 135.0, 132.7 (d, J = 8.2 Hz), 132.3, 130.5, 128.1 (d, J = 3.7 Hz), 127.3, 126.0, 125.5, 124.9, 124.3, 115.1 (d, J = 21.1 Hz), 113.3, 111.7, 110.3, 108.1, 107.6, 101.1, 50.6, 42.1. HRMS $\left(\mathrm{ESI}^{+}\right.$) for $\mathrm{C}_{30} \mathrm{H}_{23} \mathrm{NO}_{5} \mathrm{~F}^{+}$; calculated 496.15548 , found 496.15479 (error $\mathrm{m} / \mathrm{z}=$ $-1.39 \mathrm{ppm})$.

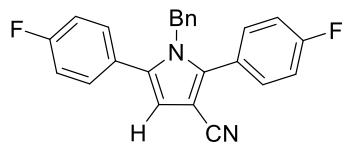

1-benzyl-2,5-bis(4-fluorophenyl)-1H-pyrrole-3-carbonitrile (8ab) Isolated yield $60 \%$. Red-orange solid. $\mathrm{H}$ NMR $\left(500 \mathrm{MHz}, \mathrm{CDCl}_{3}\right)$ :

$\delta 7.36(\mathrm{dd}, \mathrm{J}=8.8,5.2 \mathrm{~Hz}, 2 \mathrm{H}), 7.25(\mathrm{ddd}, \mathrm{J}=8.8,5.4,2.4,2 \mathrm{H})$, 7.20-7.18 (m, 3H), $7.10(\mathrm{t}, \mathrm{J}=5.5 \mathrm{~Hz}, 2 \mathrm{H}), 7.03(\mathrm{t}, \mathrm{J}=8.8 \mathrm{~Hz}, 2 \mathrm{H})$, 6.64-6.62 (m, 2H), $6.56(\mathrm{~s}, 1 \mathrm{H}), 5.09(\mathrm{~s}, 2 \mathrm{H}) .{ }^{13} \mathrm{C} \mathrm{NMR}\left(126 \mathrm{MHz}, \mathrm{CDCl}_{3}\right): \delta 164.2(\mathrm{~d}, \mathrm{~J}=$ $299.4 \mathrm{~Hz}), 163.8$ (d, J = 199.6 Hz), 141.6, 137.2, 135.5, 131.7 (d, J = 9.2 Hz), 131.4 (d, J = 8.2 Hz), 128.7, 127.6, 127.5, 125.7, 125.6 (d, J = 3.7 Hz), 116.8, 116.1 (d, J = 21.1 Hz), $115.8(\mathrm{~d}, \mathrm{~J}=22.0 \mathrm{~Hz}), 112.1,93.6,49.0$. HRMS $\left(\mathrm{ESI}^{+}\right)$for $\mathrm{C}_{24} \mathrm{H}_{17} \mathrm{~N}_{2} \mathrm{~F}_{2}{ }^{+}$; calculated 371.13543 , found 371.13520 (error $\mathrm{m} / \mathrm{z}=-0.62 \mathrm{ppm}$ ).

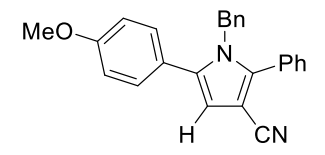

1-benzyl-5-(4-methoxyphenyl)-2-phenyl-1H-pyrrole-3-carbonitrile (8ac)

Isolated yield 77\%. White solid. ${ }^{1} \mathrm{H}$ NMR $\left(500 \mathrm{MHz}, \mathrm{CDCl}_{3}\right): \delta 7.41-$ $7.39(\mathrm{~m}, 5 \mathrm{H}), 7.23(\mathrm{~d}, \mathrm{~J}=7.9,2 \mathrm{H}), 7.18-7.17(\mathrm{~m}, 3 \mathrm{H}), 6.88(\mathrm{~d}, \mathrm{~J}=8.2$ $\mathrm{Hz}, 2 \mathrm{H}), 6.65-6.64(\mathrm{~m}, 2 \mathrm{H}), 6.55$ (s, 1H), 5.15 (s, 2H), 3.82 (s, 3H). ${ }^{13} \mathrm{C}$ NMR $(126 \mathrm{MHz}$, $\left.\mathrm{CDCl}_{3}\right): \delta 159.7,142.4,137.6,136.4,130.8,129.8,129.7,129.1,128.8,128.6,127.4$, 125.9, 123.9, 117.3, 114.0, 111.7, 93.1, 55.3, 49.0. HRMS (ESI ${ }^{+}$) for $\mathrm{C}_{25} \mathrm{H}_{19} \mathrm{~N}_{2} \mathrm{O}^{+}$; calculated 363.15029, found 363.15024 (error $\mathrm{m} / \mathrm{z}=-0.14 \mathrm{ppm}$ ).

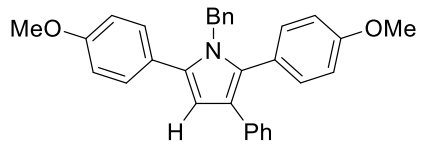

(8ad)

1-benzyl-2,5-bis(4-methoxyphenyl)-3-phenyl-1H-pyrrole Isolated yield $71 \%$. Pale yellow solid. ${ }^{1} \mathrm{H}$ NMR $(500 \mathrm{MHz}$, $\left.\mathrm{CDCl}_{3}\right): \delta 7.33(\mathrm{~d}, \mathrm{~J}=8.8 \mathrm{~Hz}, 2 \mathrm{H}), 7.26(\mathrm{dd}, \mathrm{J}=8.5,1.1 \mathrm{~Hz}$, 2H), 7.20-7.11 (m, 7H), 7.08 (tt, J = 7.3, 1.2 Hz, 1H), $6.88(\mathrm{~d}, \mathrm{~J}=8.8 \mathrm{~Hz}, 2 \mathrm{H}), 6.80(\mathrm{~d}, \mathrm{~J}=$ $8.8 \mathrm{~Hz}, 2 \mathrm{H}), 6.73(\mathrm{~d}, \mathrm{~J}=7.9 \mathrm{~Hz}, 2 \mathrm{H}), 6.54(\mathrm{~s}, 1 \mathrm{H}), 5.06(\mathrm{~s}, 2 \mathrm{H}), 3.82(\mathrm{~s}, 3 \mathrm{H}), 3.80(\mathrm{~s}, 3 \mathrm{H})$. ${ }^{13} \mathrm{C}$ NMR $\left(126 \mathrm{MHz}, \mathrm{CDCl}_{3}\right): \delta 159.1,158.9,139.4,136.4,134.9,132.5,131.4,130.4$, 128.2, 128.0, 127.4, 126.7, 126.0, 125.9, 125.5, 125.0, 122.8, 113.84, 113.8 , 108.7, 55.3, 55.2. HRMS (ESI ${ }^{+}$) for $\mathrm{C}_{31} \mathrm{H}_{27} \mathrm{NO}_{2}{ }^{+}$; calculated 445.20363, found 445.20341 (error $\mathrm{m} / \mathrm{z}=-$ $0.49 \mathrm{ppm})$.

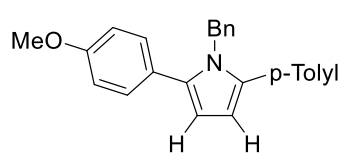

1-benzyl-2-(4-methoxyphenyl)-5-(p-tolyl)-1H-pyrrole (8ae)

Isolated yield $77 \%$. White solid. ${ }^{1} \mathrm{H}$ NMR $\left(500 \mathrm{MHz}, \mathrm{CDCl}_{3}\right): \delta$ 7.29-7.27 (m, 4H), 7.20-7.14 (m, 5H), 6.86 (d, J = 8.8 Hz, 2H), 6.73 $(\mathrm{d}, \mathrm{J}=8.2 \mathrm{~Hz}, 2 \mathrm{H}), 6.35(\mathrm{~d}, \mathrm{~J}=3.7 \mathrm{~Hz}, 1 \mathrm{H}), 6.32(\mathrm{~d}, \mathrm{~J}=3.7 \mathrm{~Hz}$, $1 \mathrm{H}), 5.22(\mathrm{~s}, 2 \mathrm{H}), 3.82(\mathrm{~s}, 3 \mathrm{H}), 2.37(\mathrm{~s}, 3 \mathrm{H}) .{ }^{13} \mathrm{C} \mathrm{NMR}\left(126 \mathrm{MHz}, \mathrm{CDCl}_{3}\right): \delta 158.8,139.6$, 136.6, 136.2, 136.1, 130.9, 130.4, 129.0, 128.9, 128.3, 126.7, 126.4, 125.9, 113.7, 109.2, 109.1, 55.3, 48.5, 21.2. HRMS $\left(\mathrm{ESI}^{+}\right)$for $\mathrm{C}_{25} \mathrm{H}_{23} \mathrm{NO}^{+}$; calculated 353.17742, found 353.17824 (error $\mathrm{m} / \mathrm{z}=2.34 \mathrm{ppm})$. 


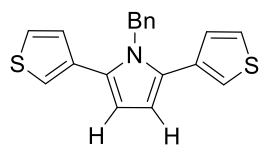

1-benzyl-2,5-di(thiophen-3-yl)-1H-pyrrole (8af)

Isolated yield $56 \%$. White solid. ${ }^{1} \mathrm{H}$ NMR $\left(500 \mathrm{MHz}, \mathrm{CDCl}_{3}\right) \delta 7.34(\mathrm{t}, J$ $=7.5 \mathrm{~Hz}, 2 \mathrm{H}), 7.28(\mathrm{~d}, J=7.4 \mathrm{~Hz}, 1 \mathrm{H}), 7.27-7.23(\mathrm{~m}, 2 \mathrm{H}), 7.07(\mathrm{dd}, J=$ $5.0,1.1 \mathrm{~Hz}, 2 \mathrm{H}), 7.02(\mathrm{~d}, J=7.4 \mathrm{~Hz}, 2 \mathrm{H}), 6.99(\mathrm{dd}, J=2.8,1.1 \mathrm{~Hz}, 2 \mathrm{H})$, $6.43(\mathrm{~s}, 2 \mathrm{H}), 5.31(\mathrm{~s}, 2 \mathrm{H}) .{ }^{13} \mathrm{C} \mathrm{NMR}\left(126 \mathrm{MHz}, \mathrm{CDCl}_{3}\right) \delta 139.7,133.8,131.2,129.1,128.5$, 127.3, 125.7, 125.4, 121.1, 109.2, 49.0. HRMS (ESI ${ }^{+}$) for $\mathrm{C}_{19} \mathrm{H}_{15} \mathrm{NS}_{2}{ }^{+}$; calculated 321.0640 , found 321.0641 (error $\mathrm{m} / \mathrm{z}=-0.3 \mathrm{ppm})$. 


\section{References}

1. Layer, R. W. Chem. Ber. 1963, 63, 489.

2. Quesnel, J. S.; Kayser, L. V.; Fabrikant, A.; Arndtsen, B. A. Chem. Eur. J. 2015, 21, 9550 .

3. Bontemps, S.; Quesnel, J. S.; Worrall, K.; Arndtsen, B. A. Angew. Chem. Int. Ed. 2011, 50, 8948.

4. Quesnel, J. S.; Arndtsen, B.A. J. Am. Chem. Soc. 2013, 135, 16841.

5. Dhawan, R.; Dghaym, R. D.; Arndtsen, B. A. J. Am. Chem. Soc. 2003, 125, 1474.

6. Dhawan, R.; Dhgaym, R. D.; St. Cyr, D. J.; Arndtsen, B. A. Org. Lett. 2006, 8, 3927

7. Lopchuck, J. M.; Gribble, G. W. Heterocycles. 2011, 2, 1617. 


\title{
VIII. NMR Spectra
}

\author{
p-Tolyl
}

${ }^{1} H$ and ${ }^{31} P$ NMR data of $4 a$

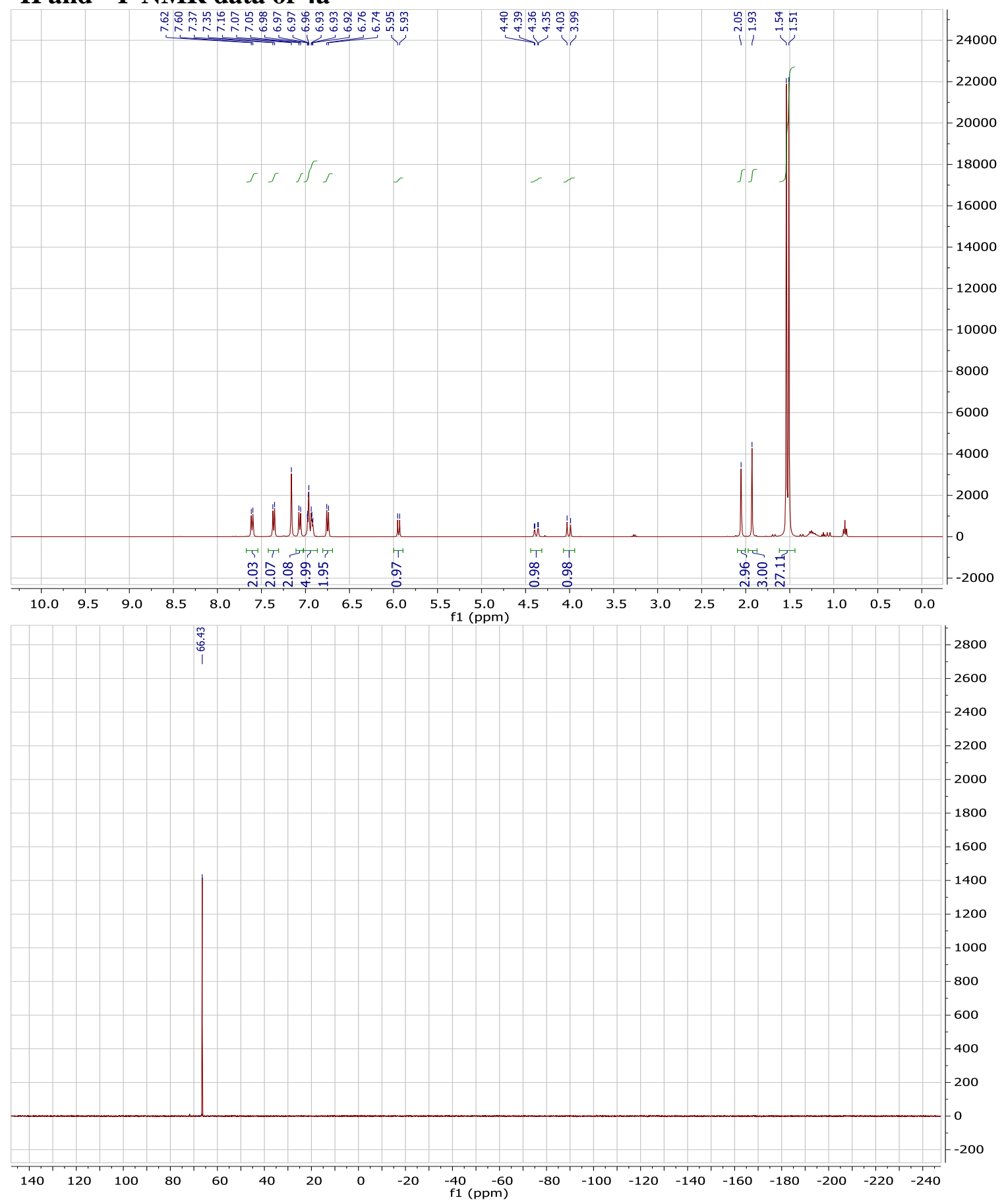




\section{${ }^{13} \mathrm{C}$ NMR data of 4a}

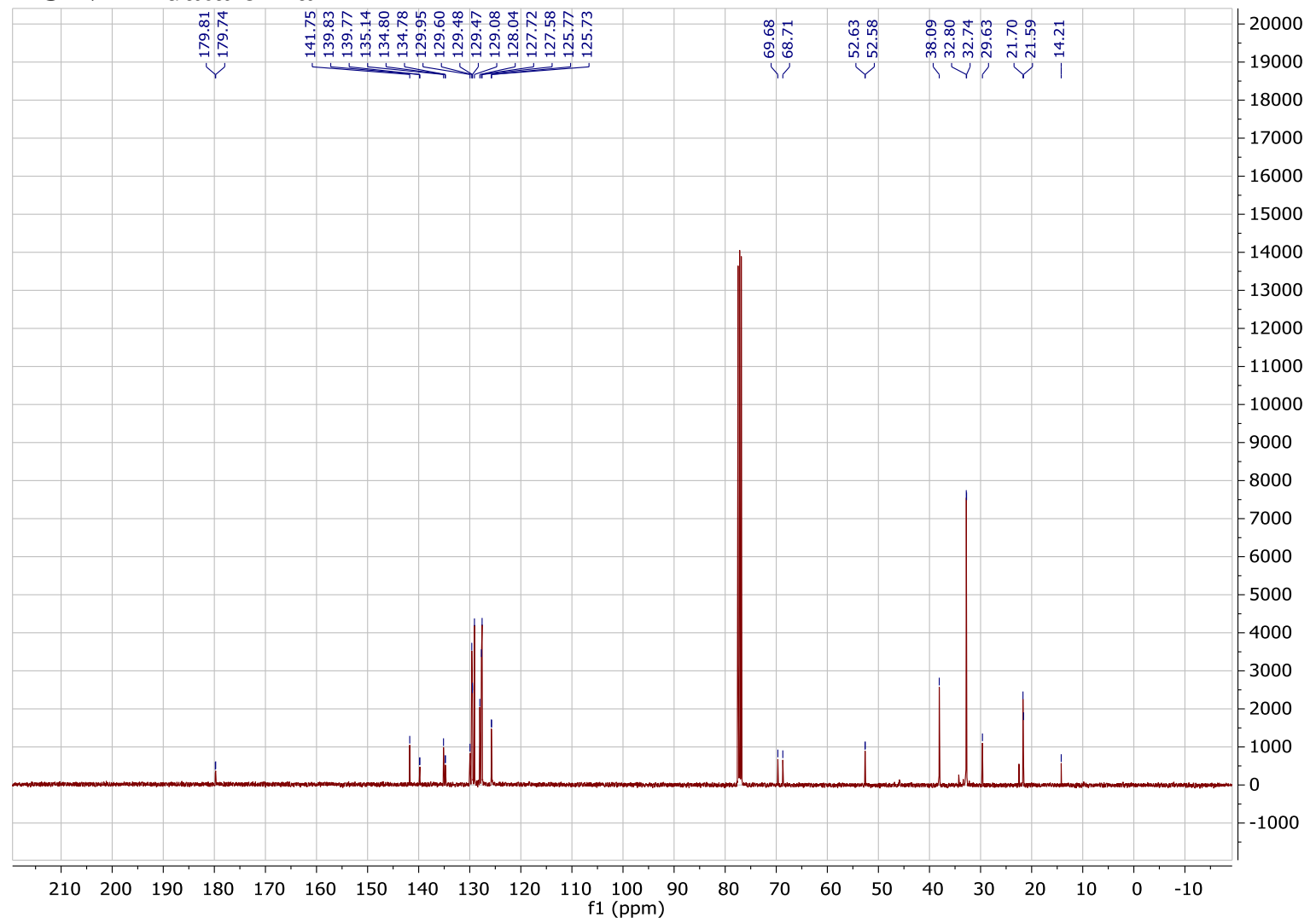




\section{NOESY spectrum of $4 a$}
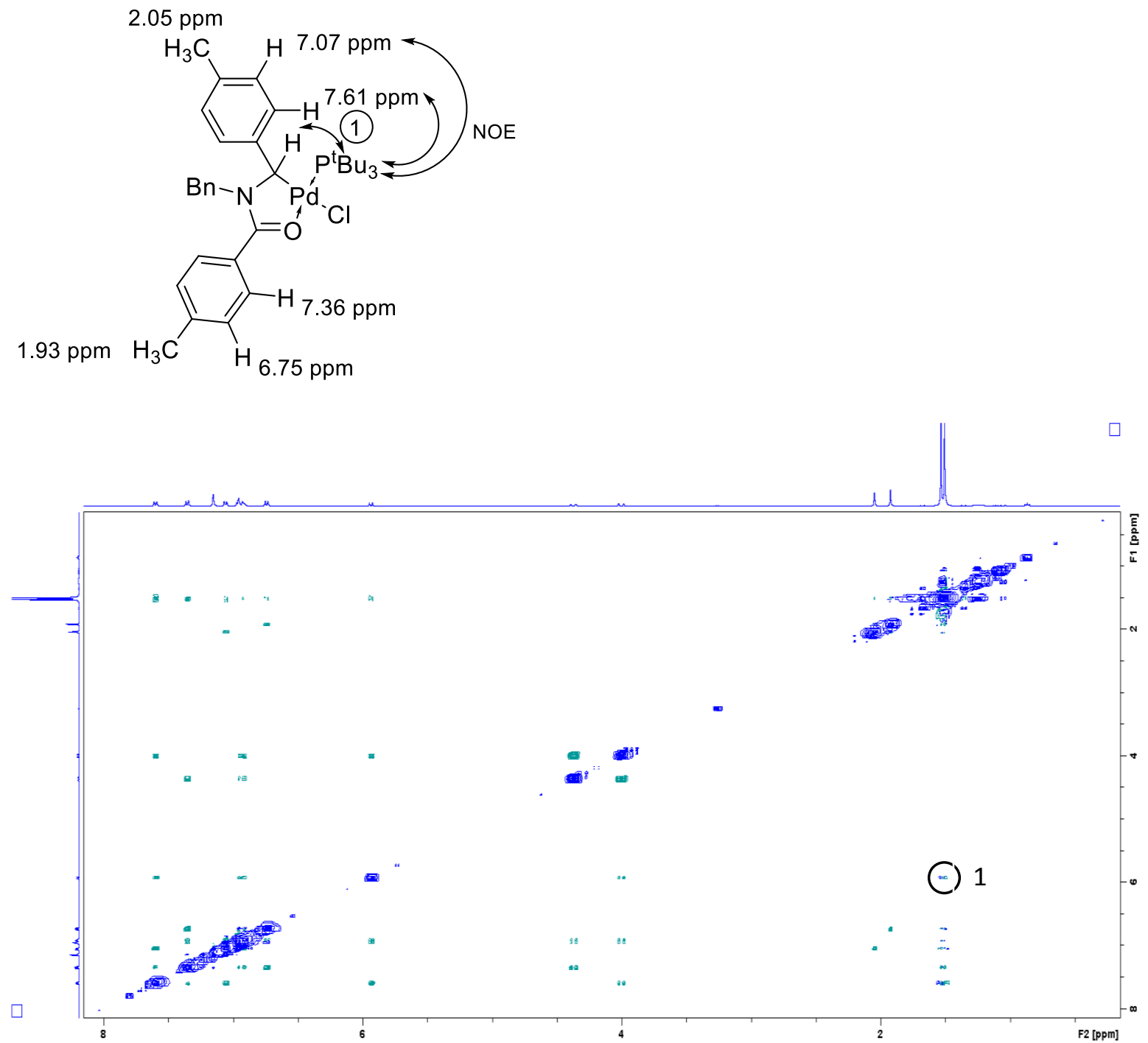
NOESY spectrum of 4a (zoom in tert-butyl region)

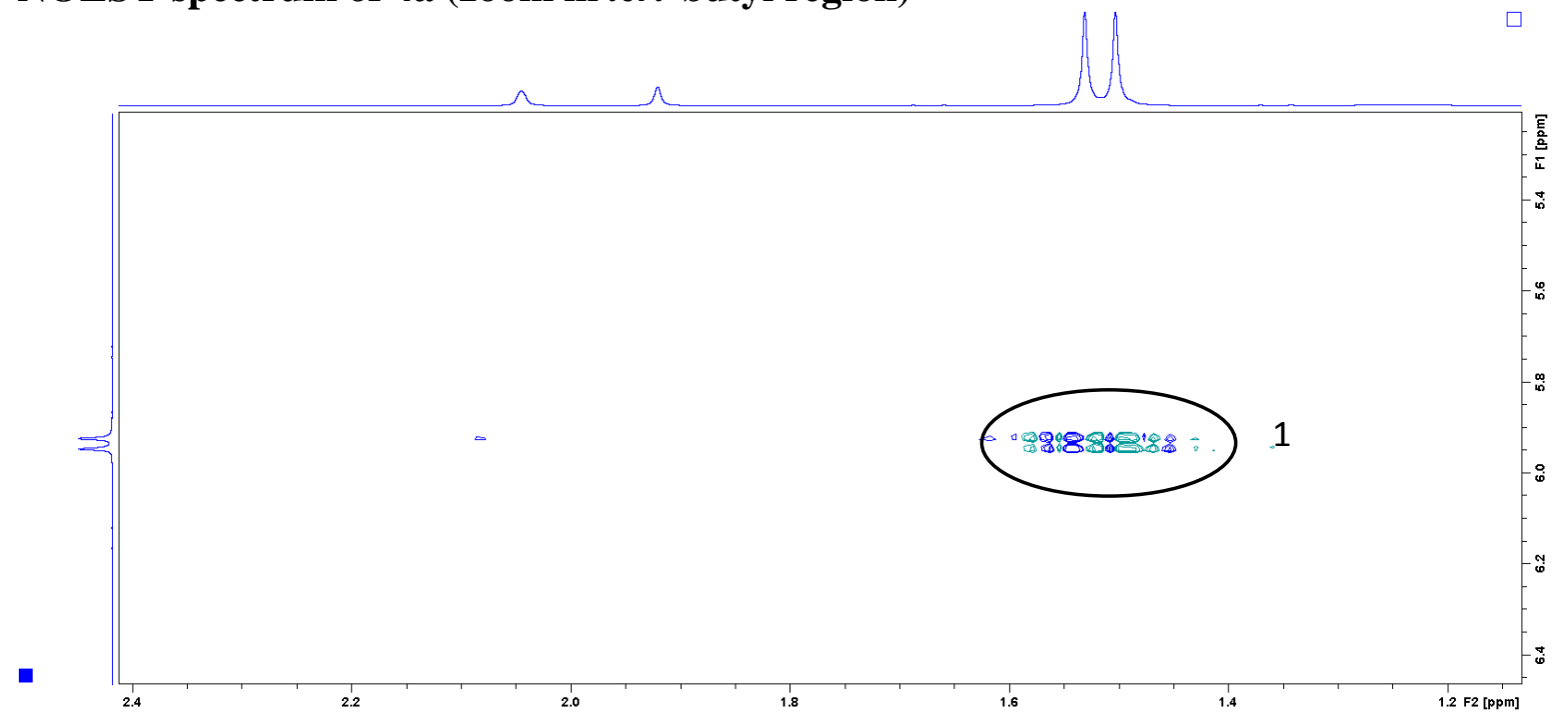




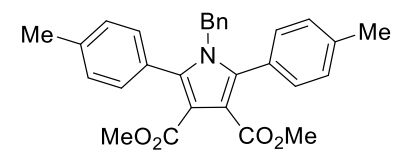

\section{${ }^{1} \mathrm{H}$ and ${ }^{13} \mathrm{C}$ NMR data for $8 \mathrm{a}$}

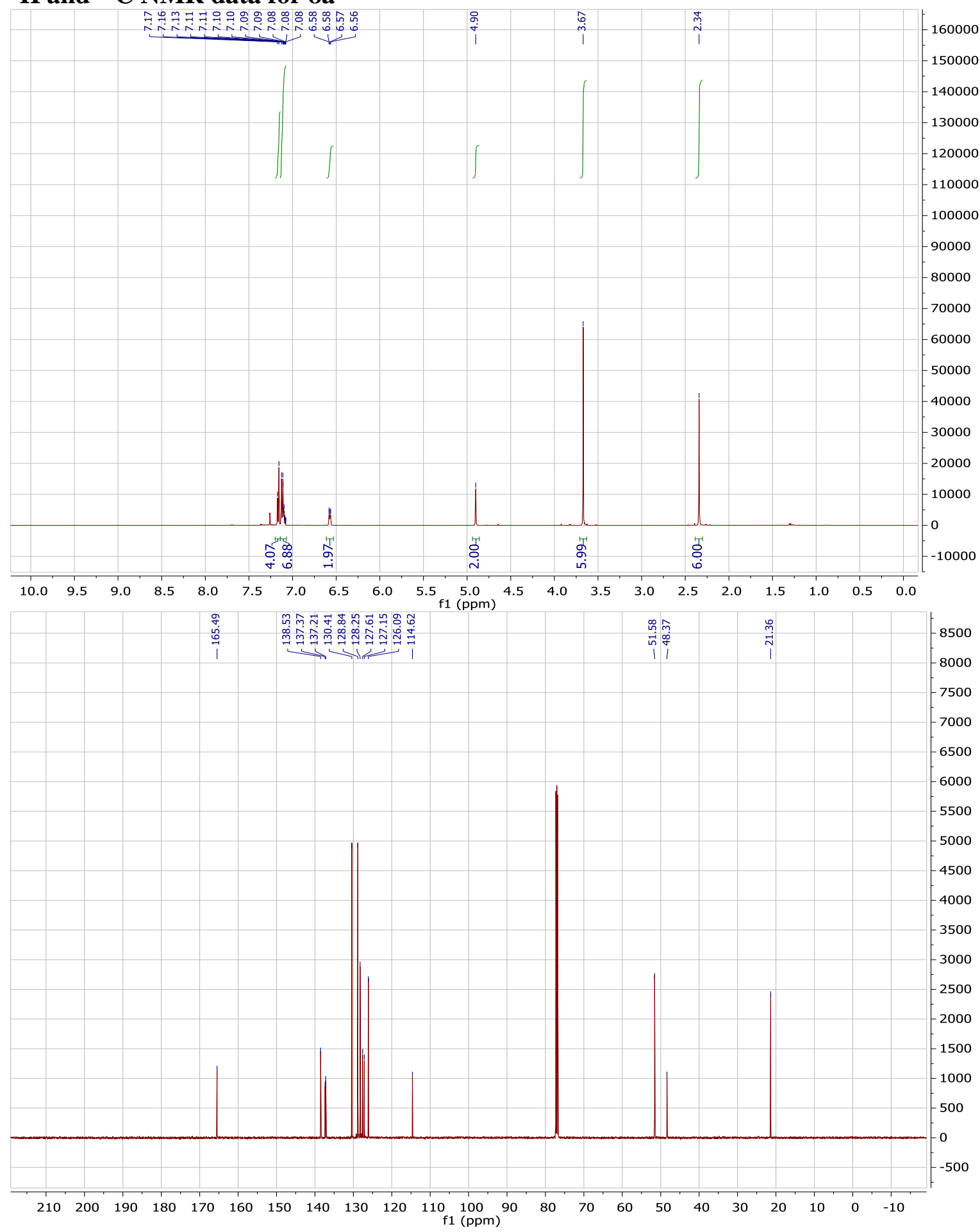




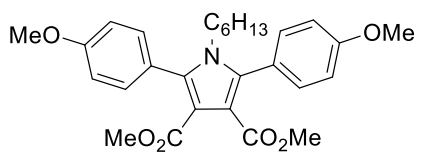

\section{${ }^{1} \mathrm{H}$ and ${ }^{13} \mathrm{C}$ NMR data for $8 \mathrm{~b}$}

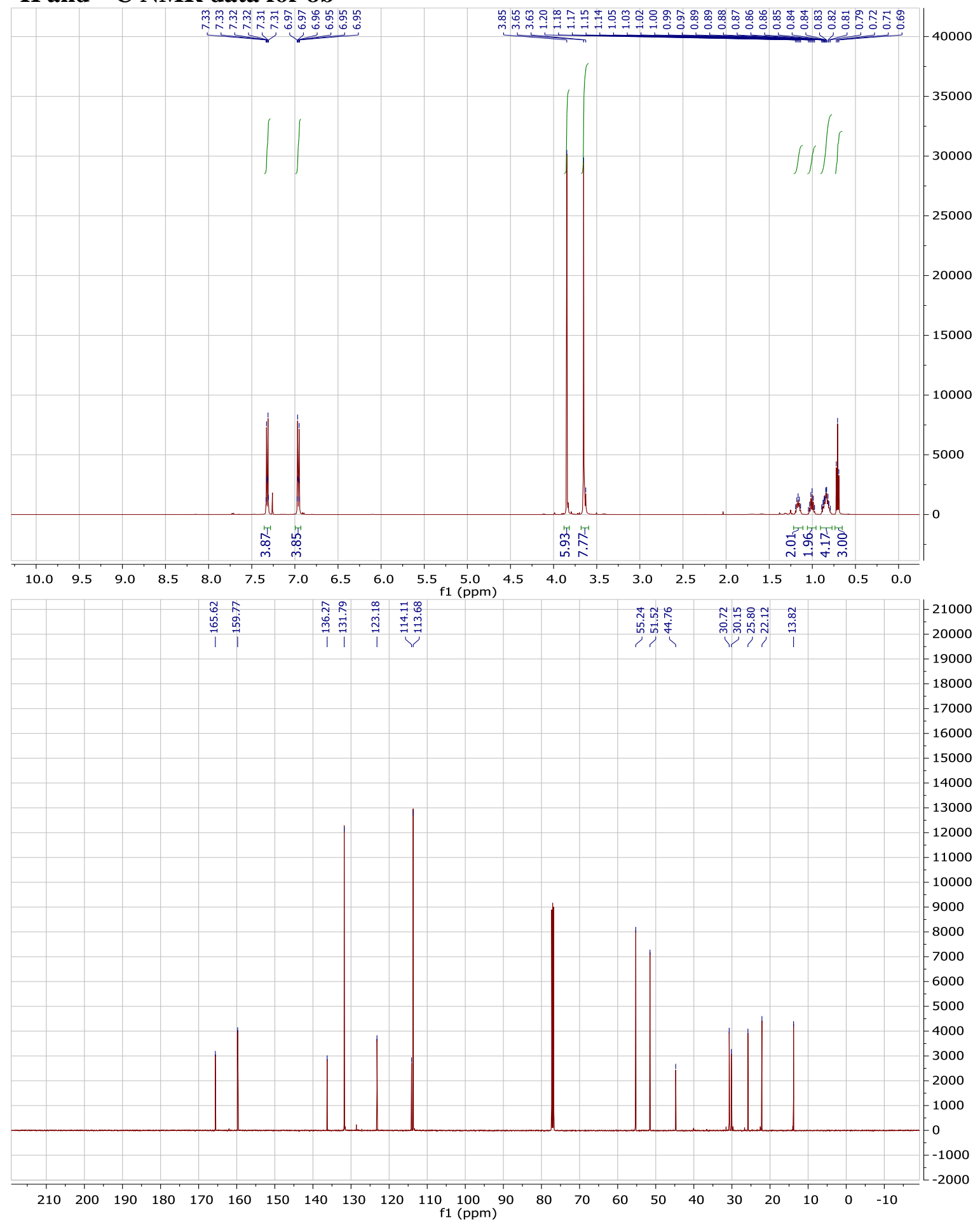




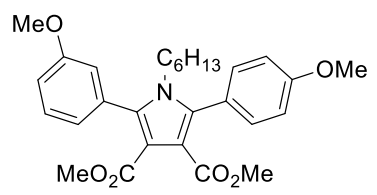

\section{${ }^{1} \mathrm{H}$ and ${ }^{13} \mathrm{C}$ NMR data for $8 \mathrm{c}$}
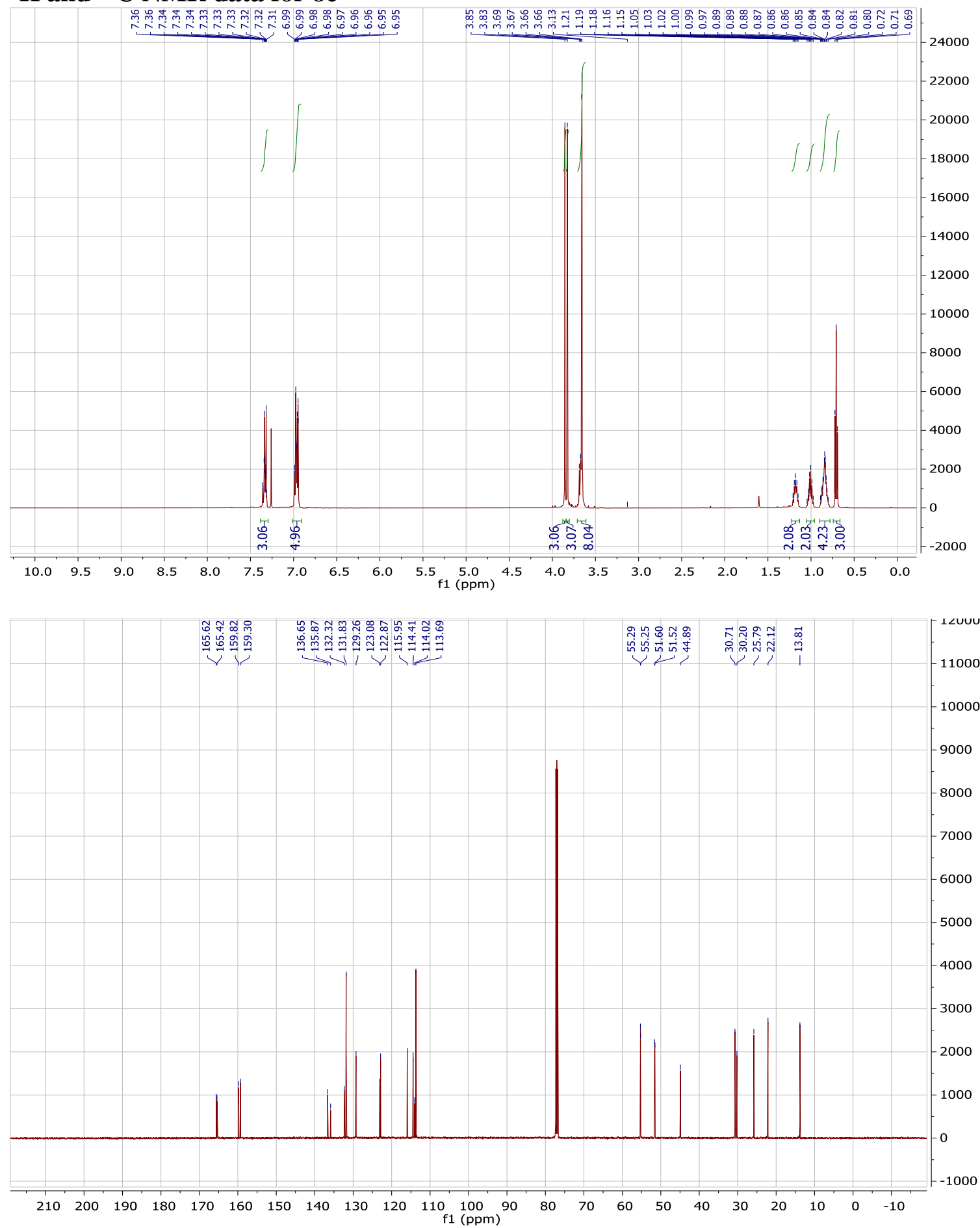


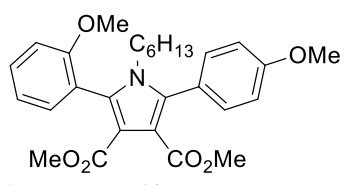

${ }^{1} \mathrm{H}$ and ${ }^{13} \mathrm{C}$ NMR data for $8 d$

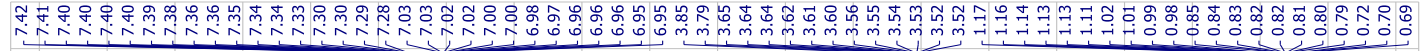
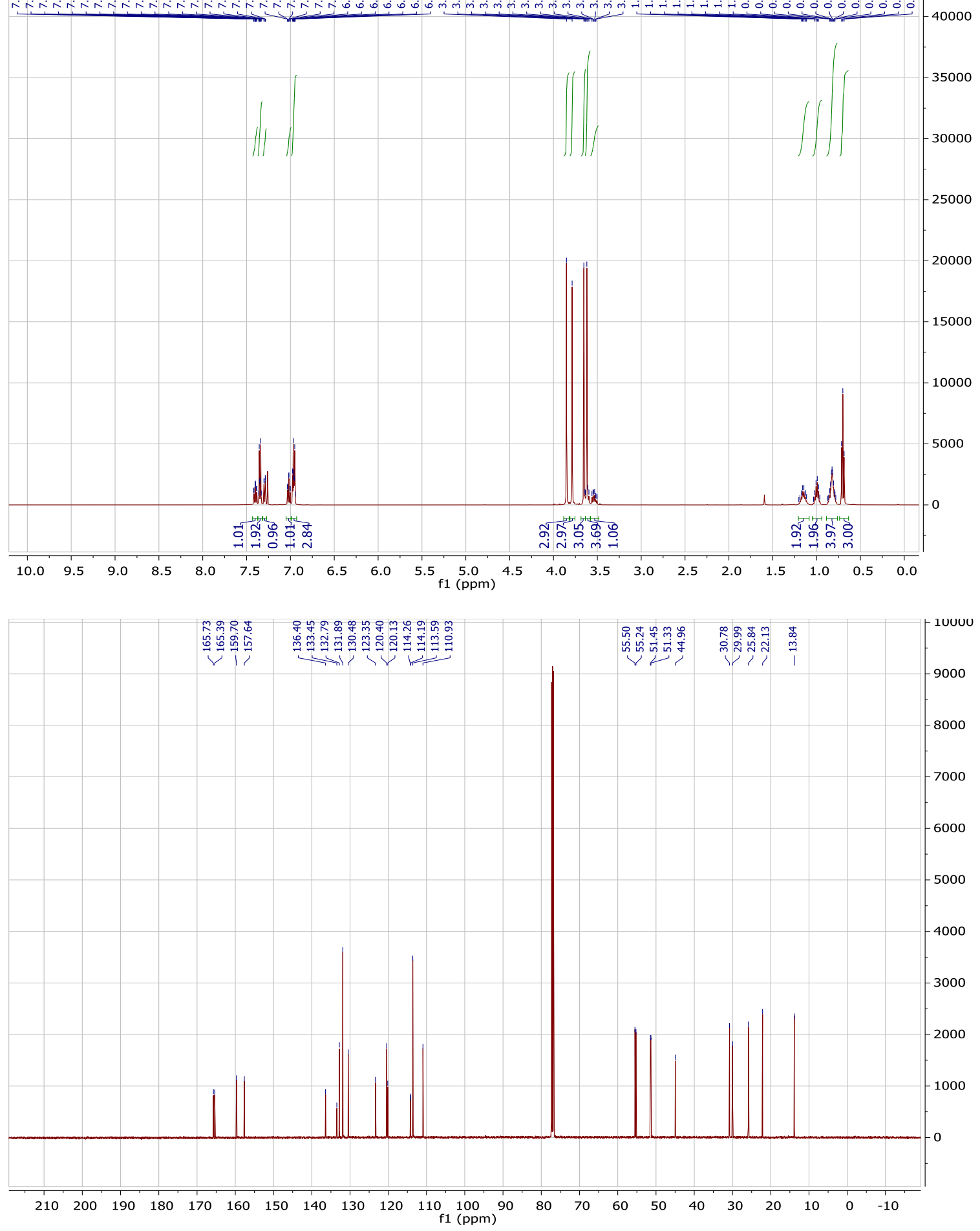


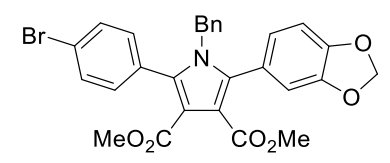

\section{${ }^{1} \mathrm{H}$ and ${ }^{13} \mathrm{C}$ NMR data for $8 \mathrm{e}$}
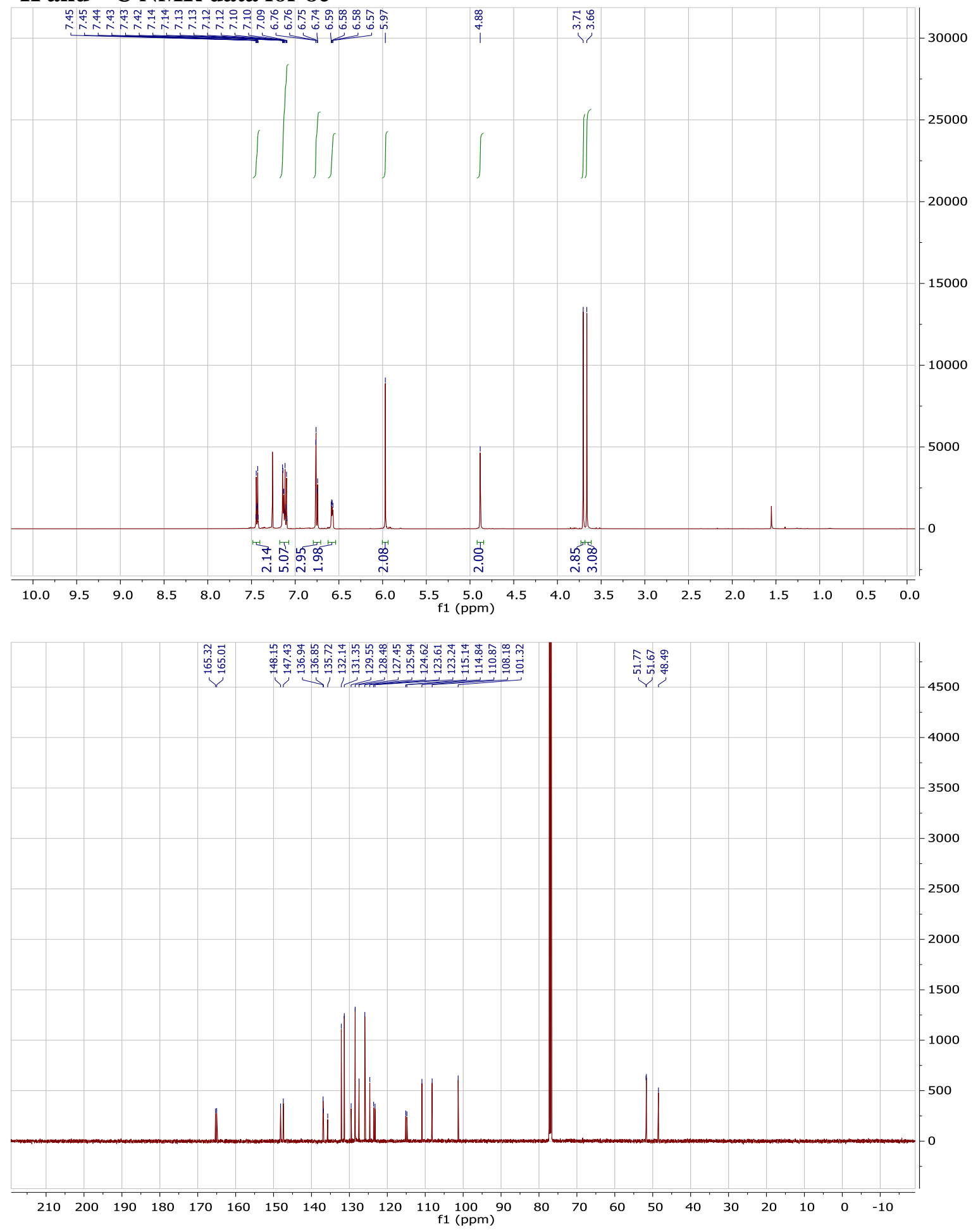
<smiles></smiles>

\section{${ }^{1} \mathrm{H}$ and ${ }^{13} \mathrm{C}$ NMR data for $8 f$}
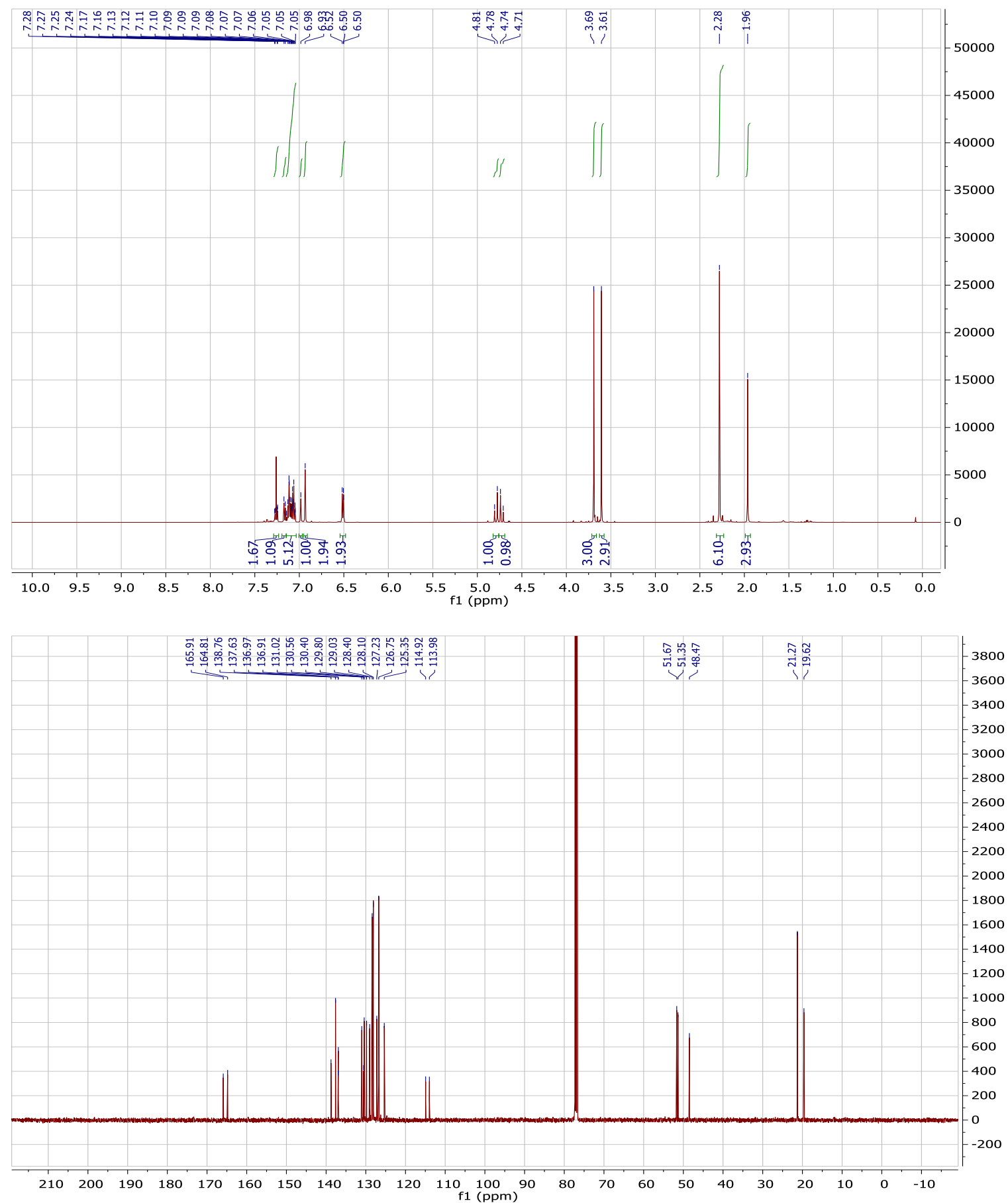


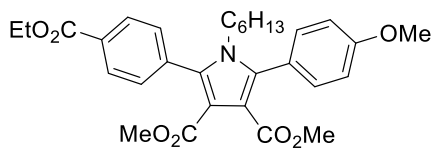

\section{${ }^{1} \mathrm{H}$ and ${ }^{13} \mathrm{C}$ NMR data for $8 \mathrm{~g}$}
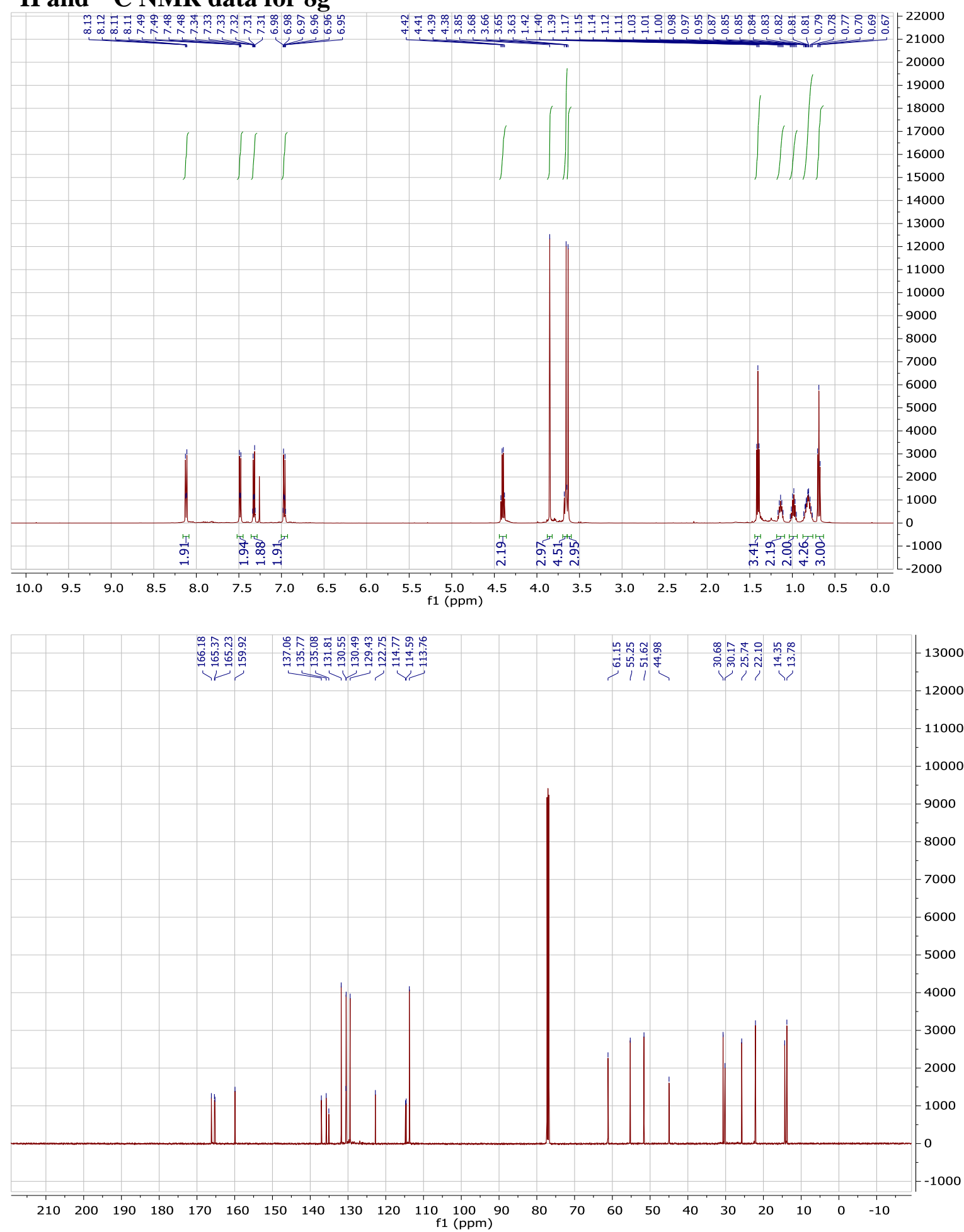


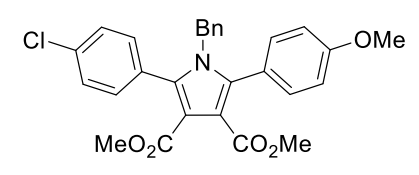

\section{${ }^{1} \mathrm{H}$ and ${ }^{13} \mathrm{C}$ NMR data for $8 \mathrm{~h}$}
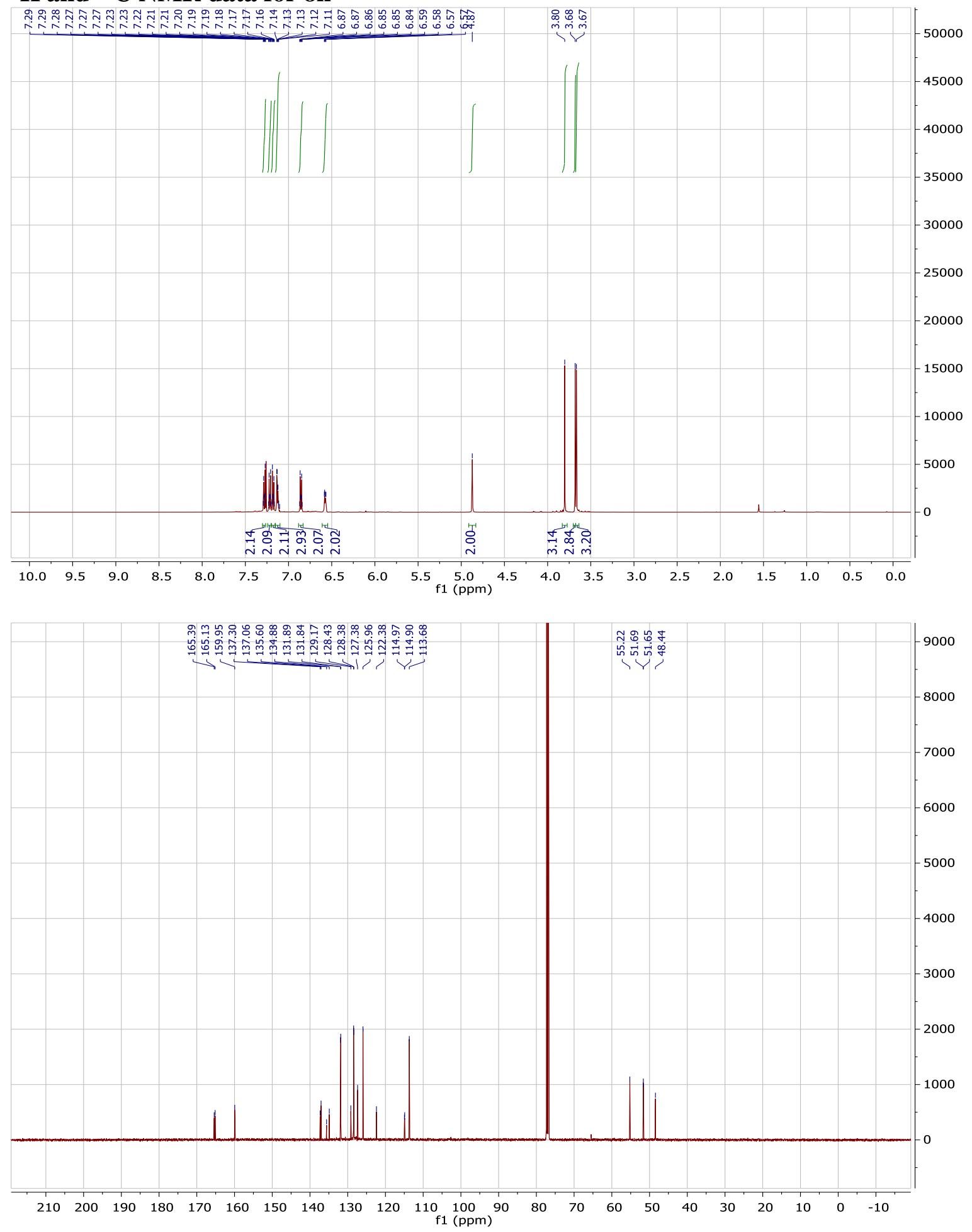


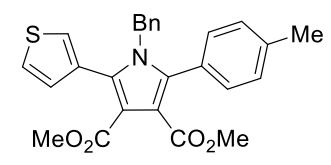

\section{${ }^{1} \mathrm{H}$ and ${ }^{13} \mathrm{C}$ NMR data for $8 \mathrm{i}$}
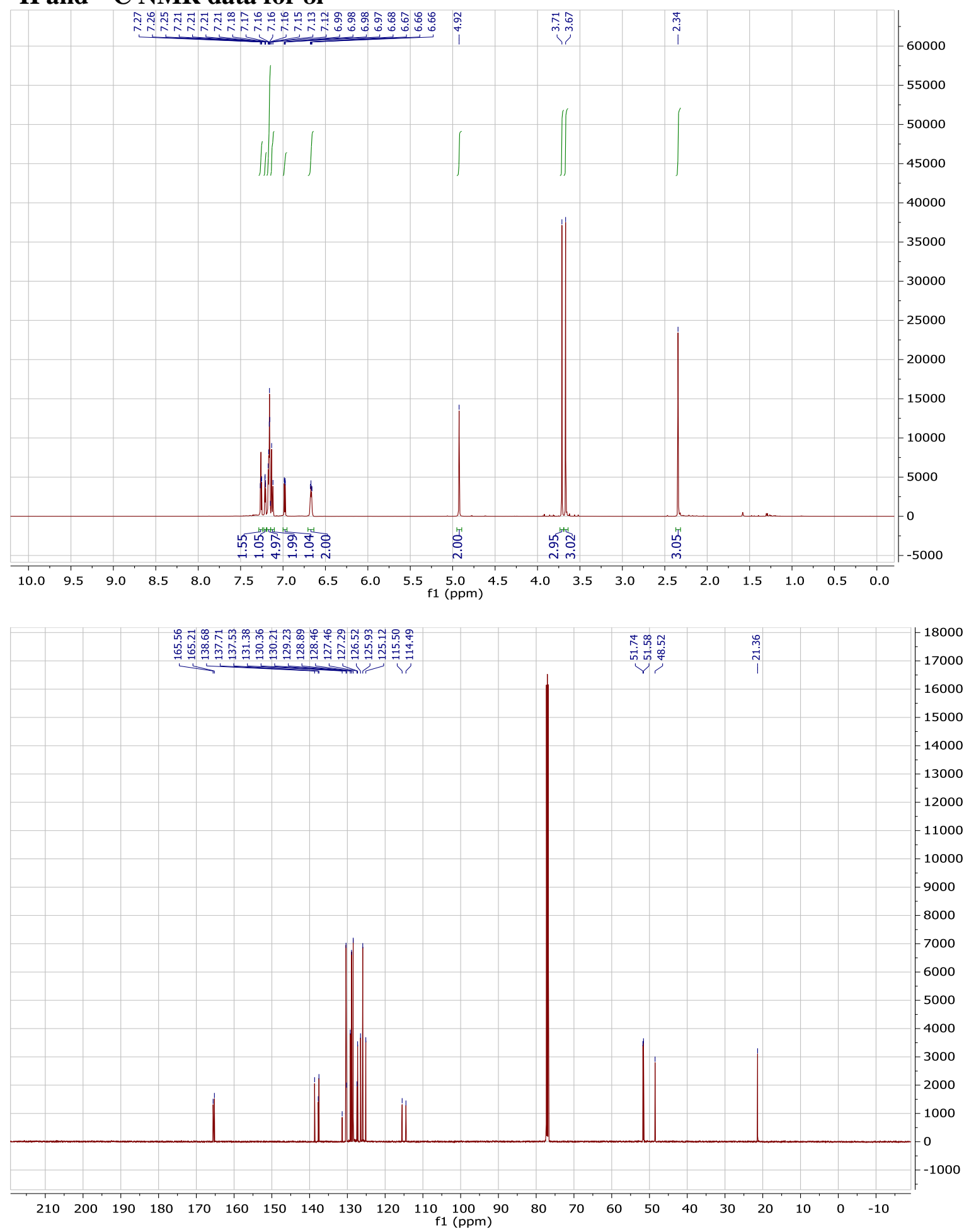
<smiles></smiles>

\section{${ }^{1} \mathrm{H}$ and ${ }^{13} \mathrm{C}$ NMR data for $8 \mathrm{j}$}
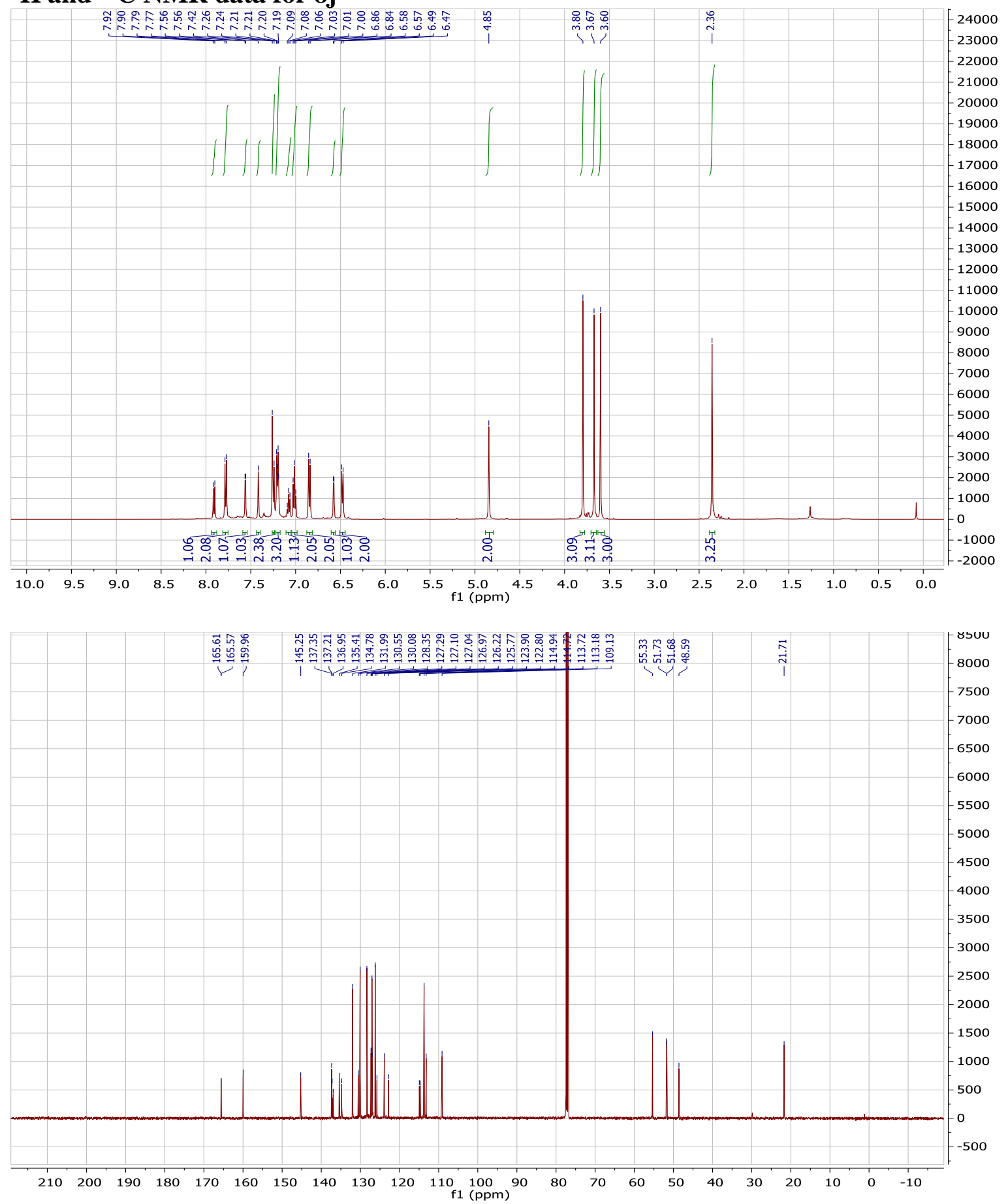


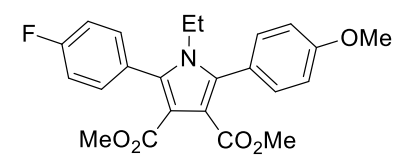

\section{${ }^{1} \mathrm{H}$ and ${ }^{13} \mathrm{C}$ NMR data for $8 \mathrm{k}$}
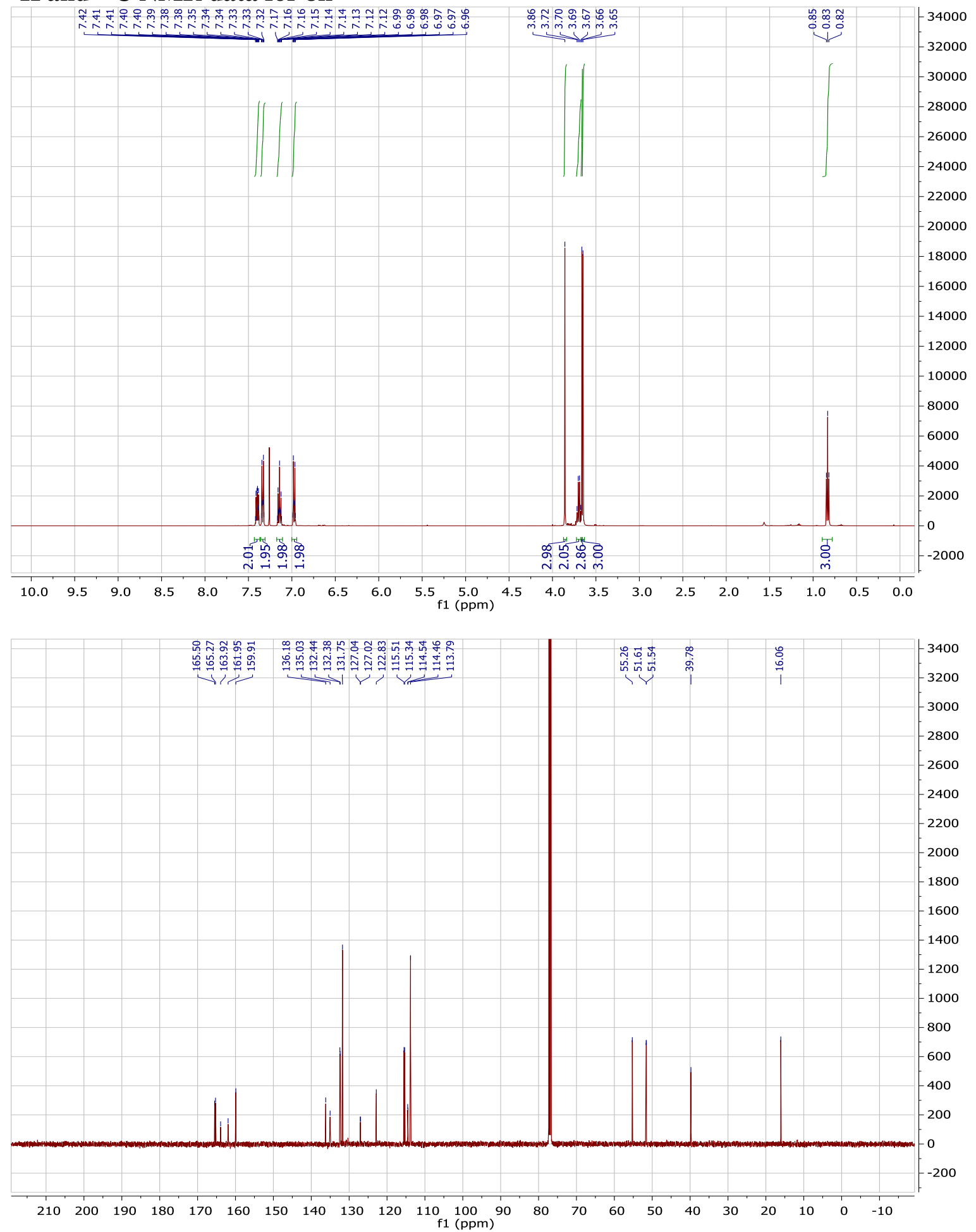


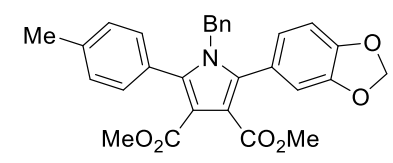

\section{${ }^{1} \mathrm{H}$ and ${ }^{13} \mathrm{C}$ NMR data for 81}
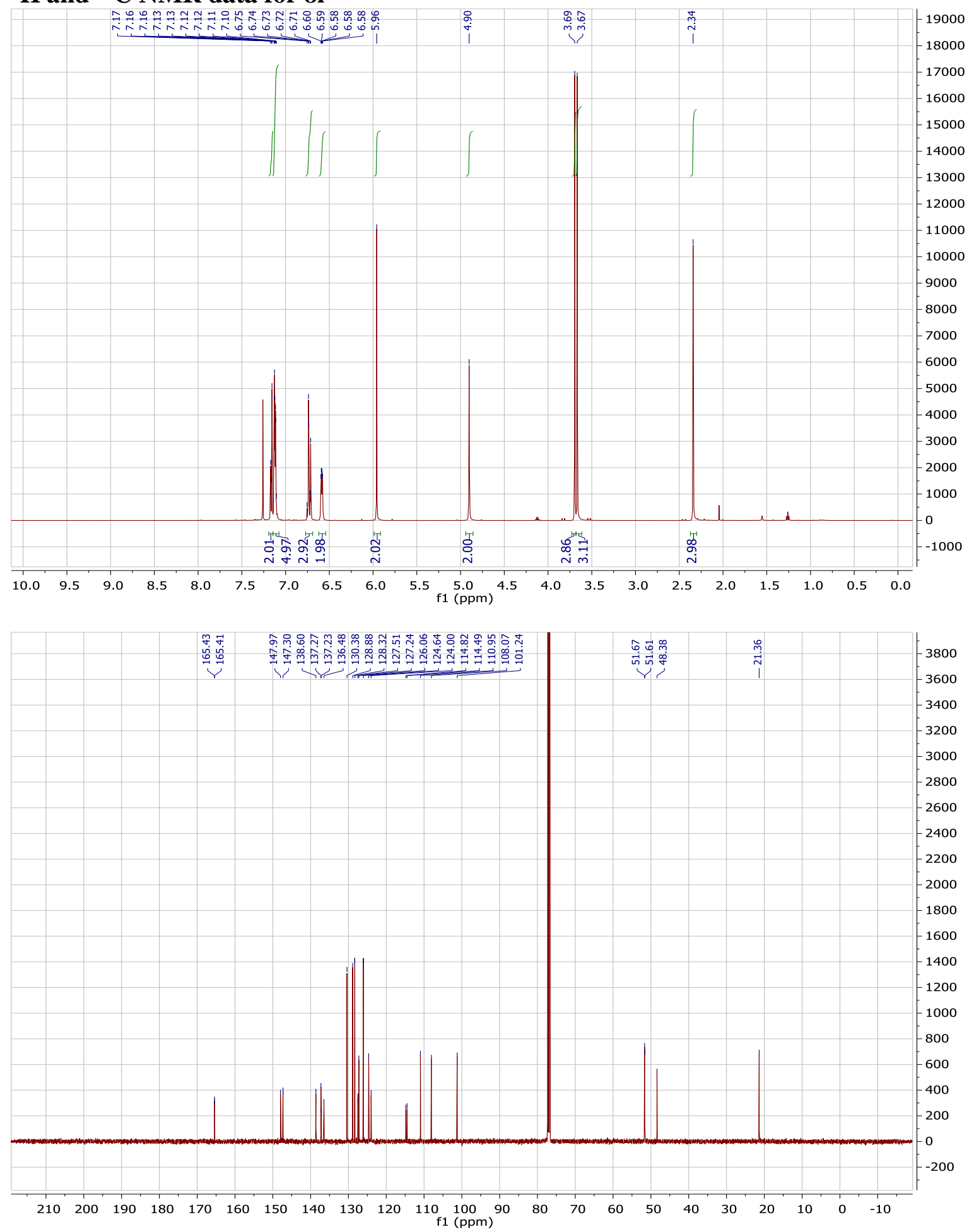
<smiles>CCn1c(-c2ccc(OC)cc2)c(C(C)=O)c(C(=O)OC)c1-c1cccc(Br)c1</smiles>

\section{${ }^{1} \mathrm{H}$ and ${ }^{13} \mathrm{C}$ NMR data for $8 \mathrm{~m}$}

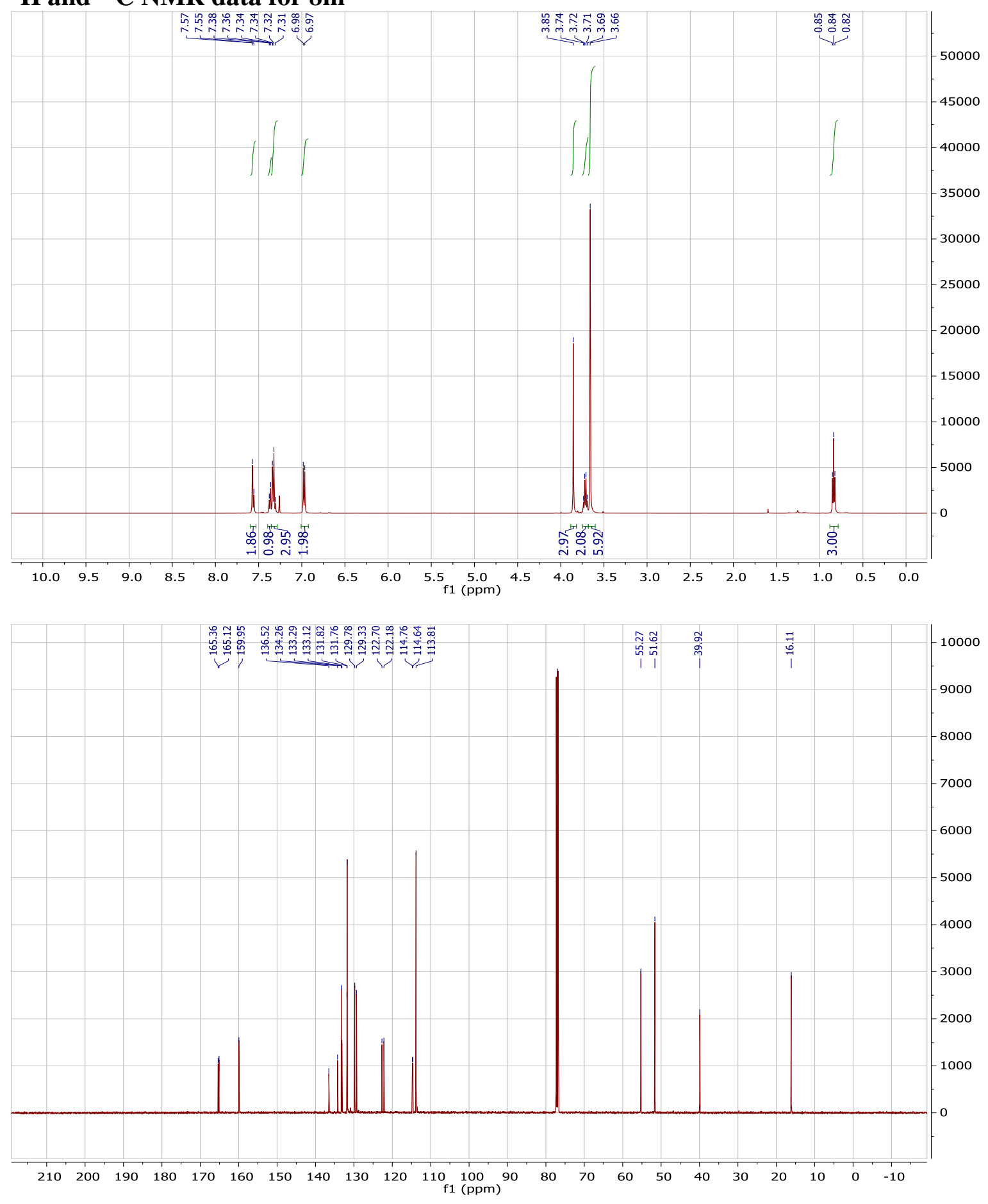




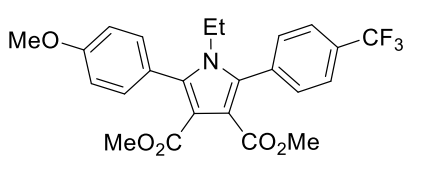

${ }^{1} \mathrm{H}$ and ${ }^{13} \mathrm{C}$ NMR data for $8 \mathrm{n}$
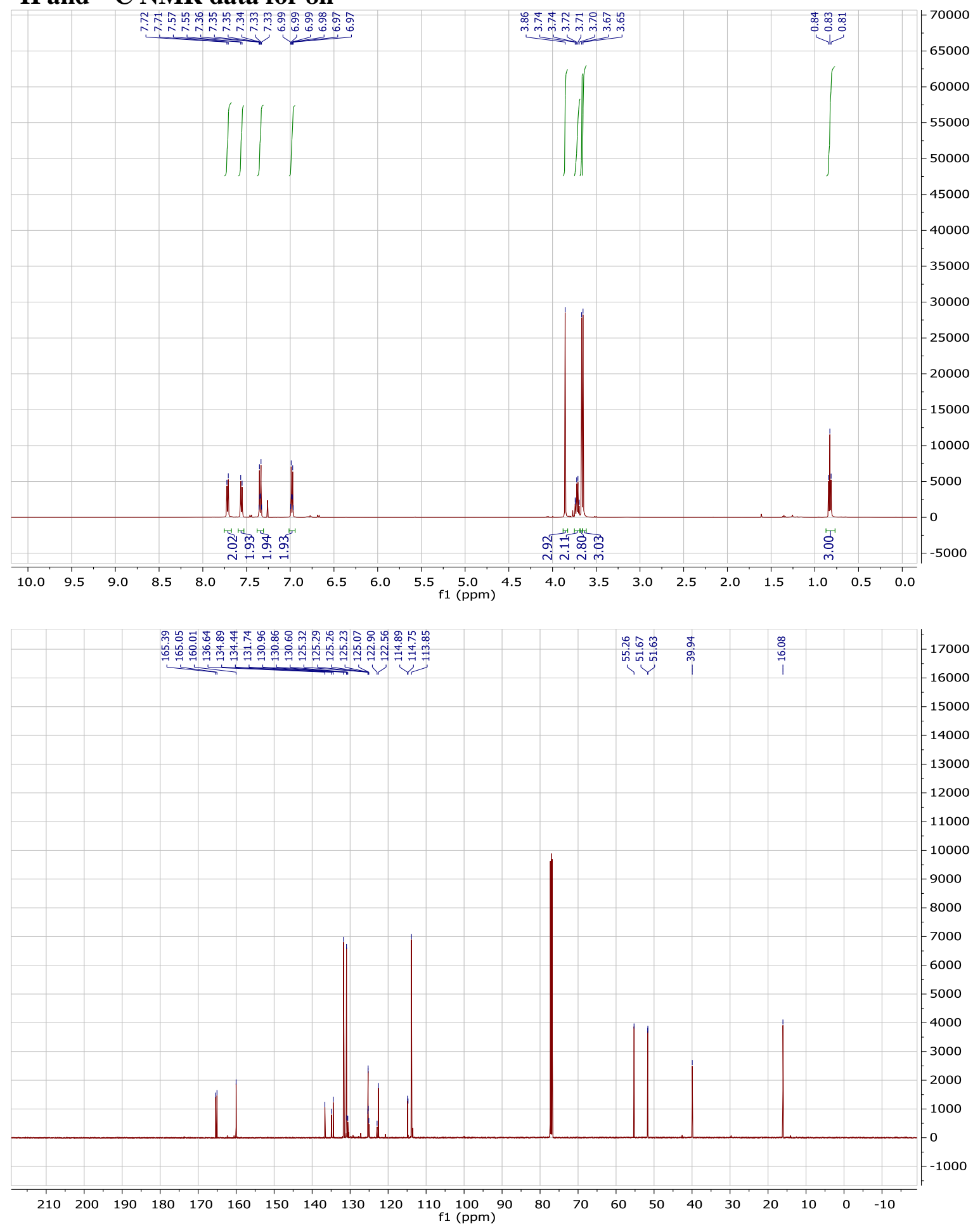


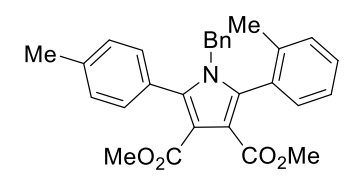

${ }^{1} \mathrm{H}$ and ${ }^{13} \mathrm{C}$ NMR data for 80
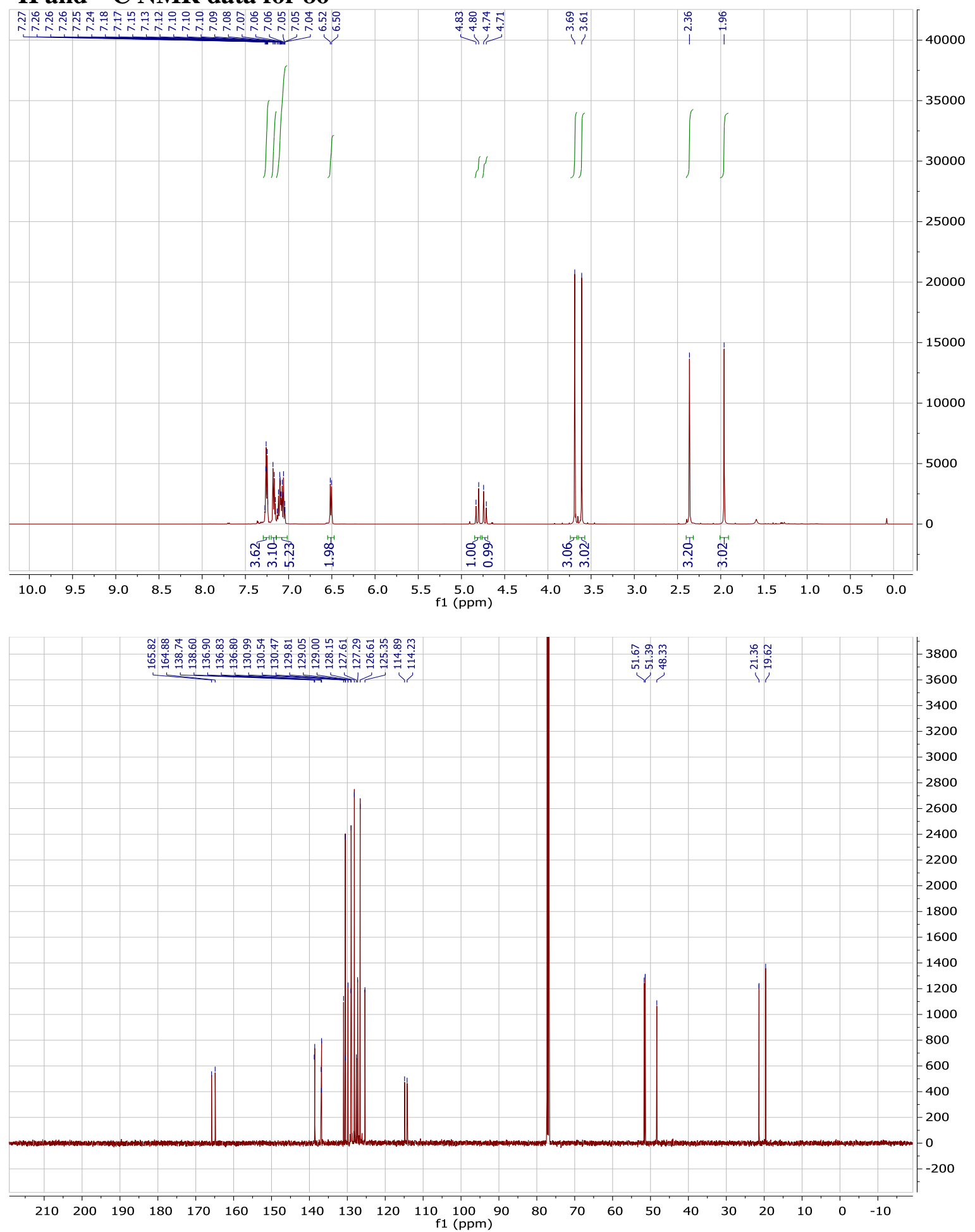


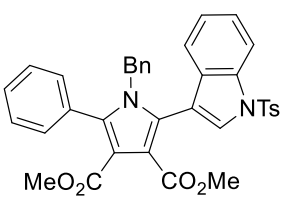

\section{${ }^{1} \mathrm{H}$ and ${ }^{13} \mathrm{C}$ NMR data for $8 p$}
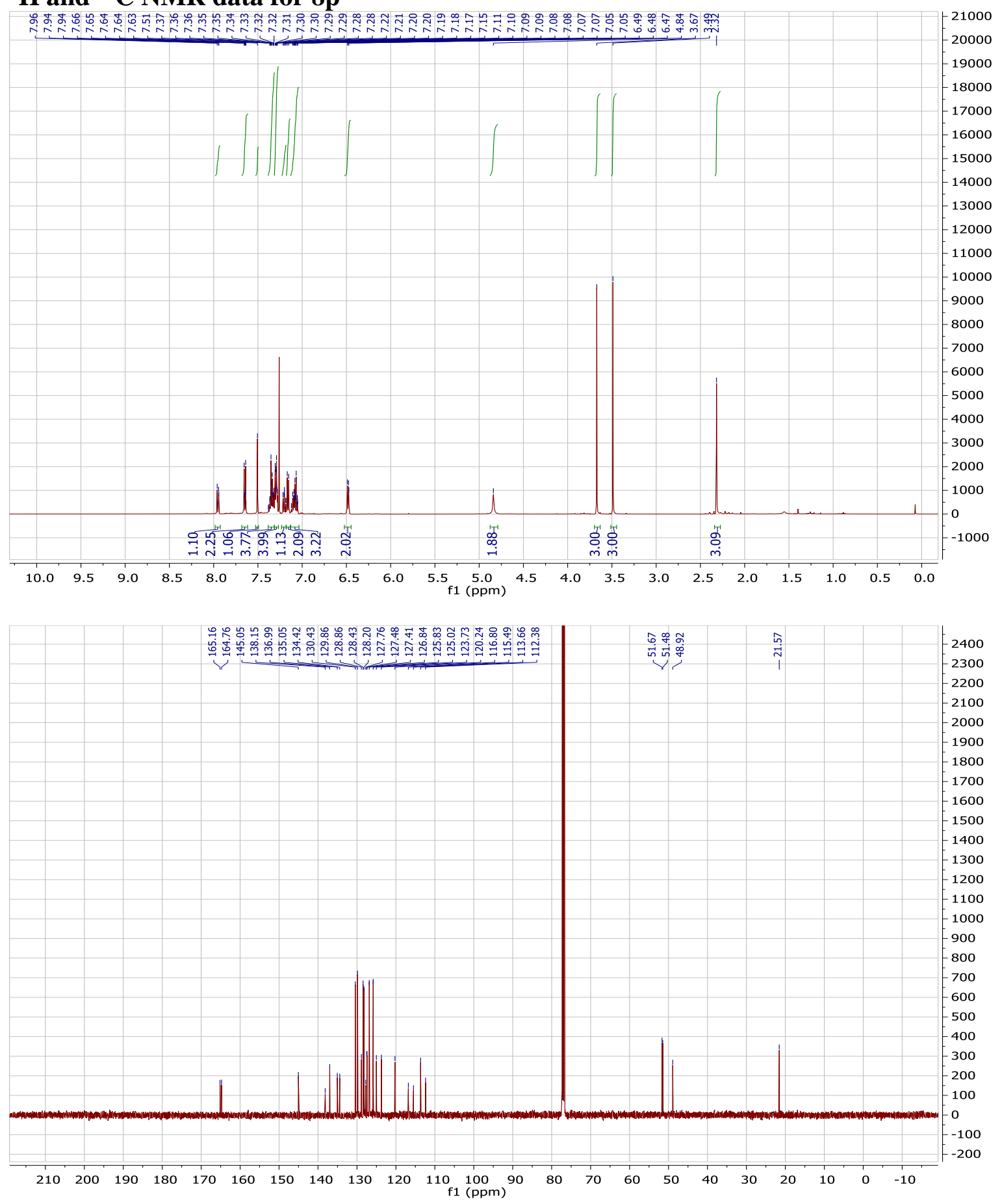


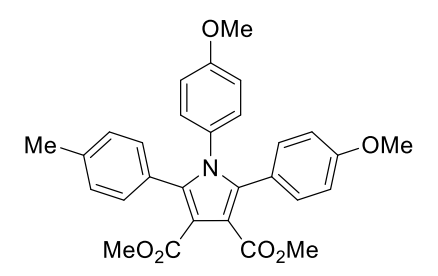

\section{${ }^{1} \mathrm{H}$ and ${ }^{13} \mathrm{C}$ NMR data for $8 \mathrm{q}$}
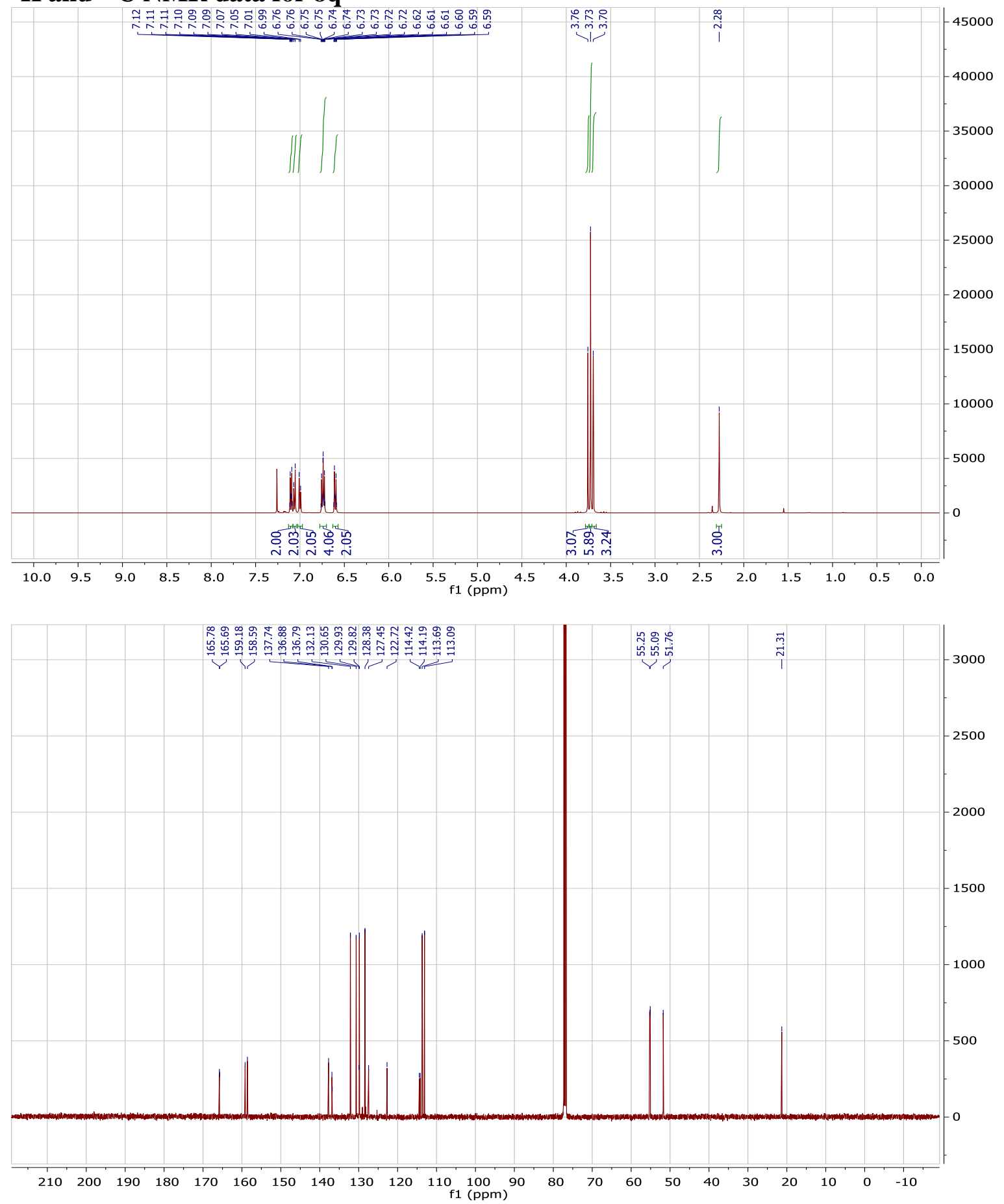


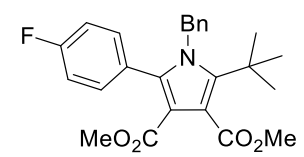

\section{${ }^{1} \mathrm{H}$ and ${ }^{13} \mathrm{C}$ NMR data for $8 \mathrm{r}$}
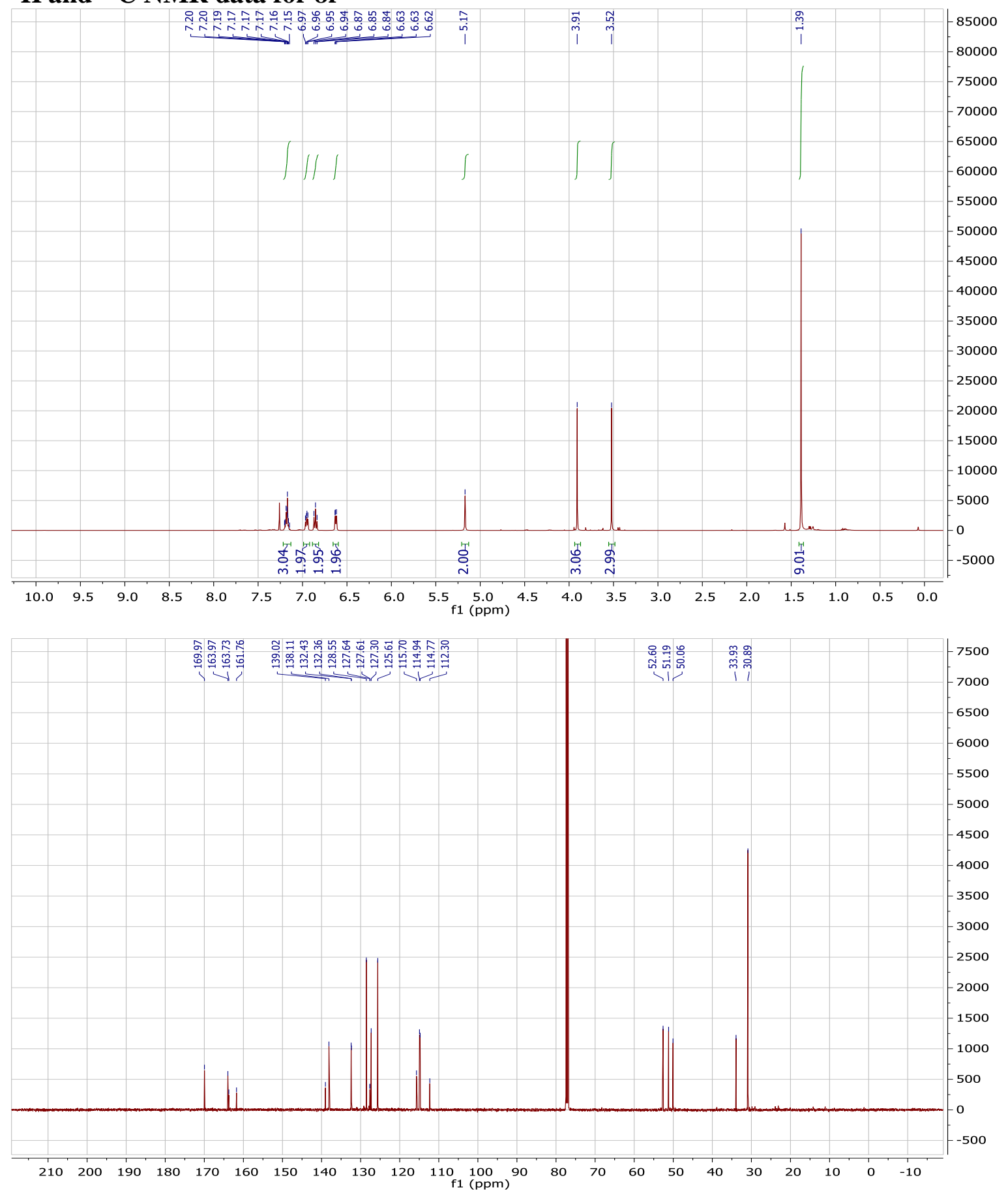


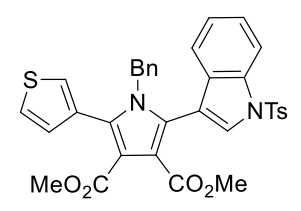

\section{${ }^{1} \mathrm{H}$ and ${ }^{13} \mathrm{C}$ NMR data for $8 \mathrm{~s}$}

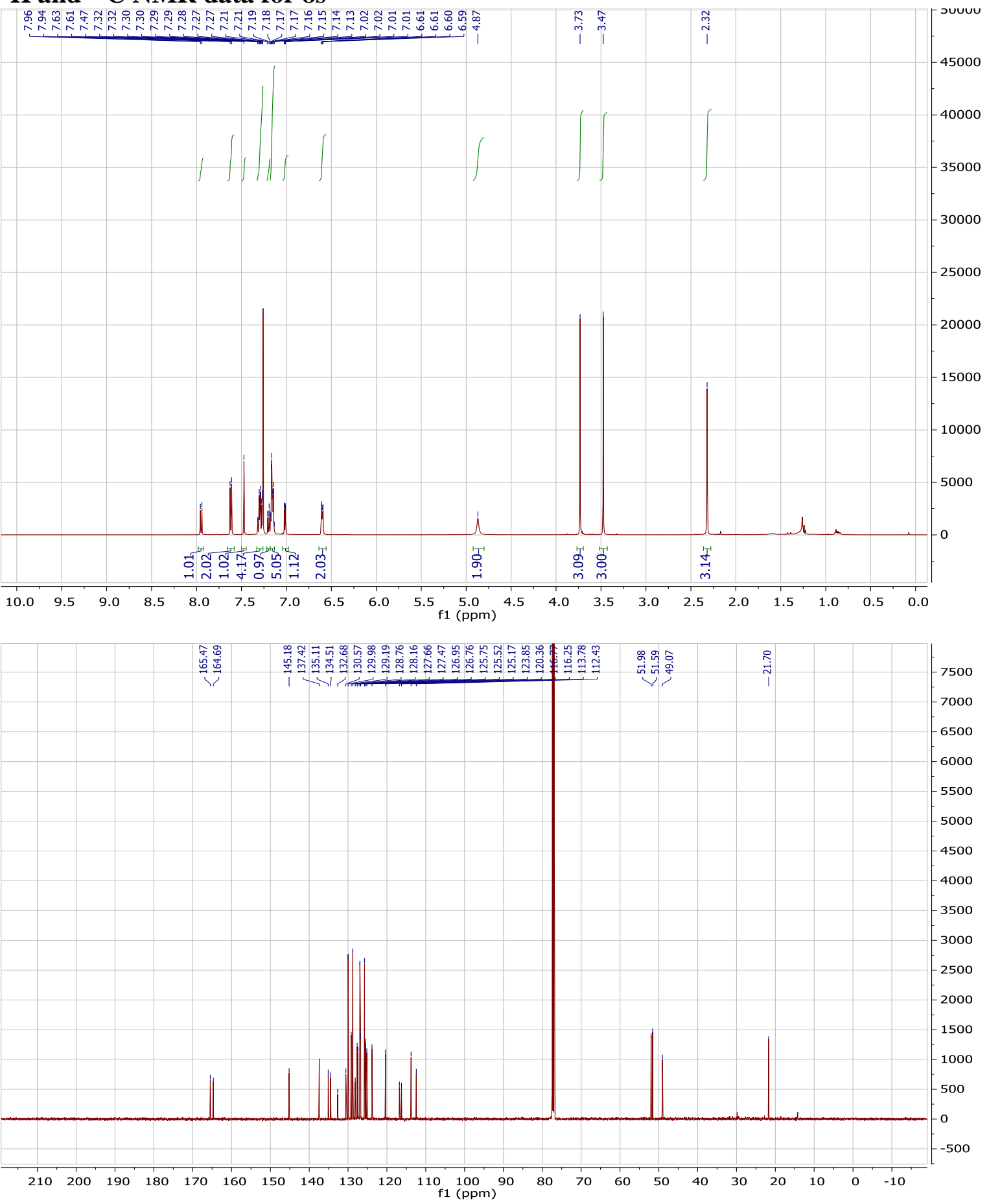




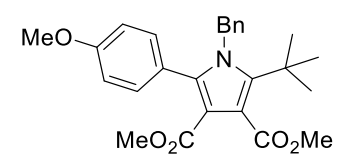

\section{${ }^{1} \mathrm{H}$ and ${ }^{13} \mathrm{C}$ NMR data for $8 \mathrm{t}$}
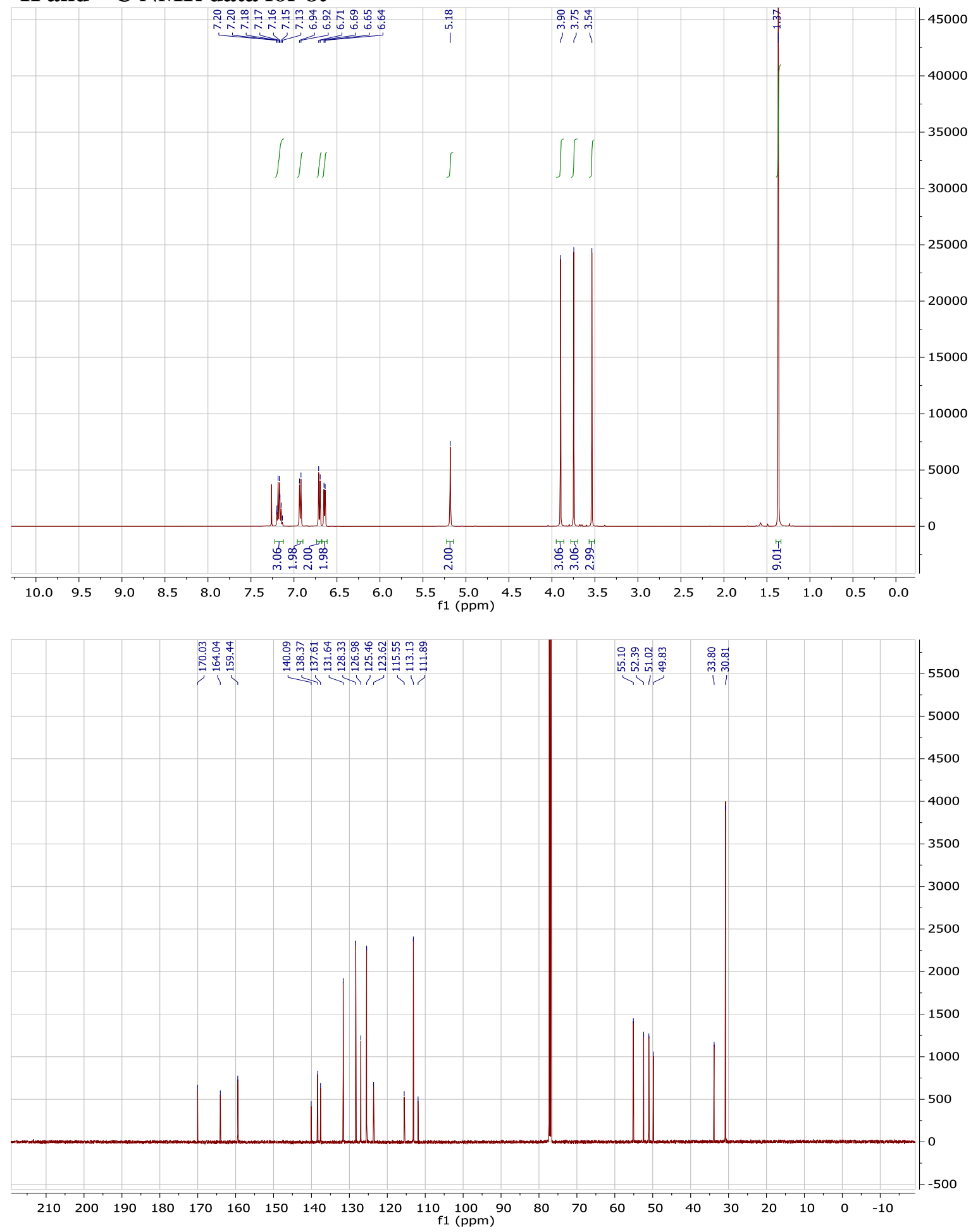


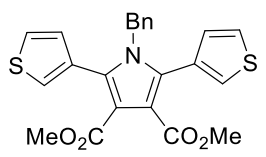

${ }^{1} \mathrm{H}$ and ${ }^{13} \mathrm{C}$ NMR data for $8 \mathrm{u}$
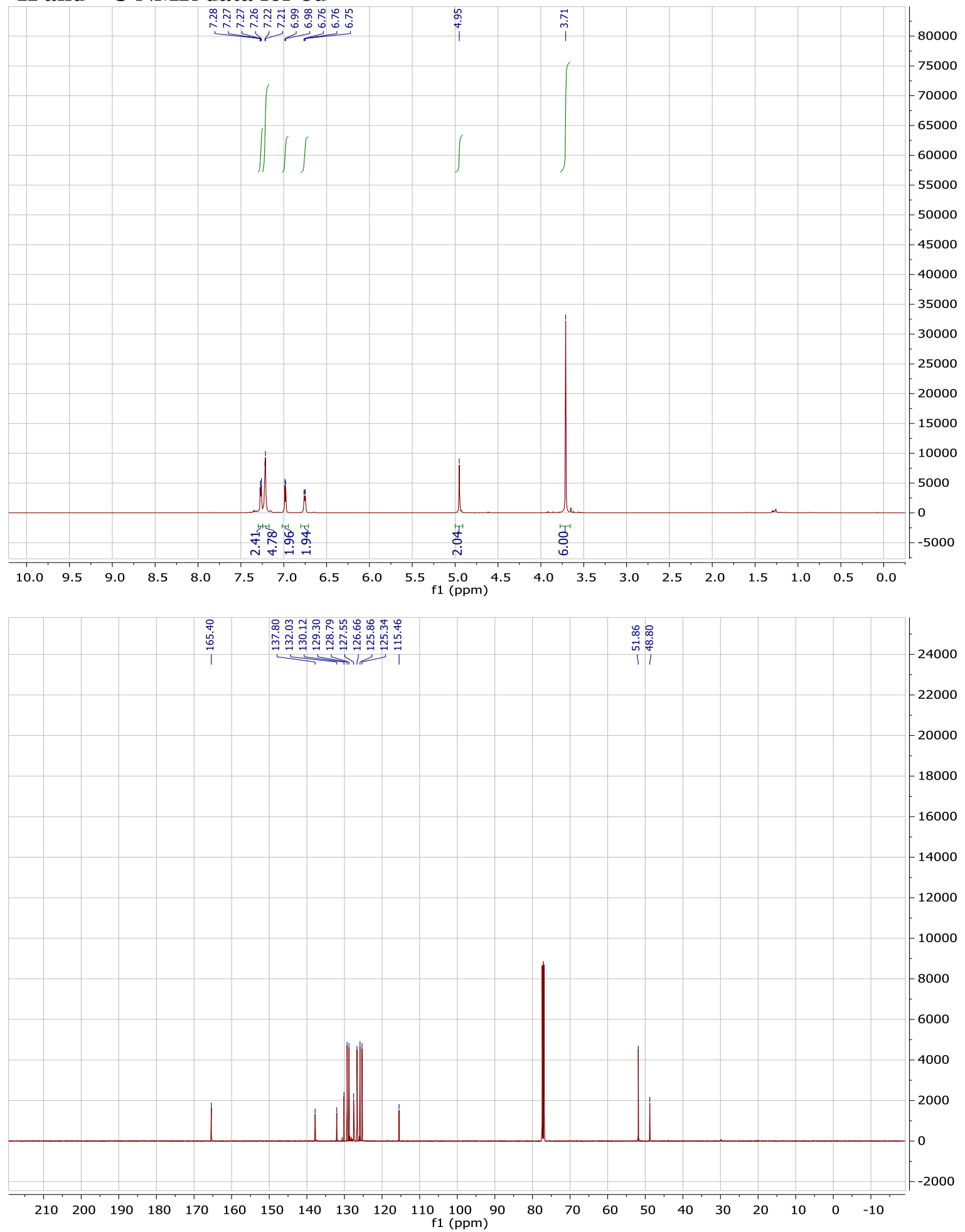


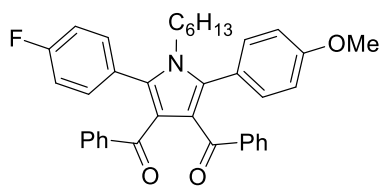

\section{${ }^{1} \mathrm{H}$ and ${ }^{13} \mathrm{C}$ NMR data for $8 \mathrm{v}$}
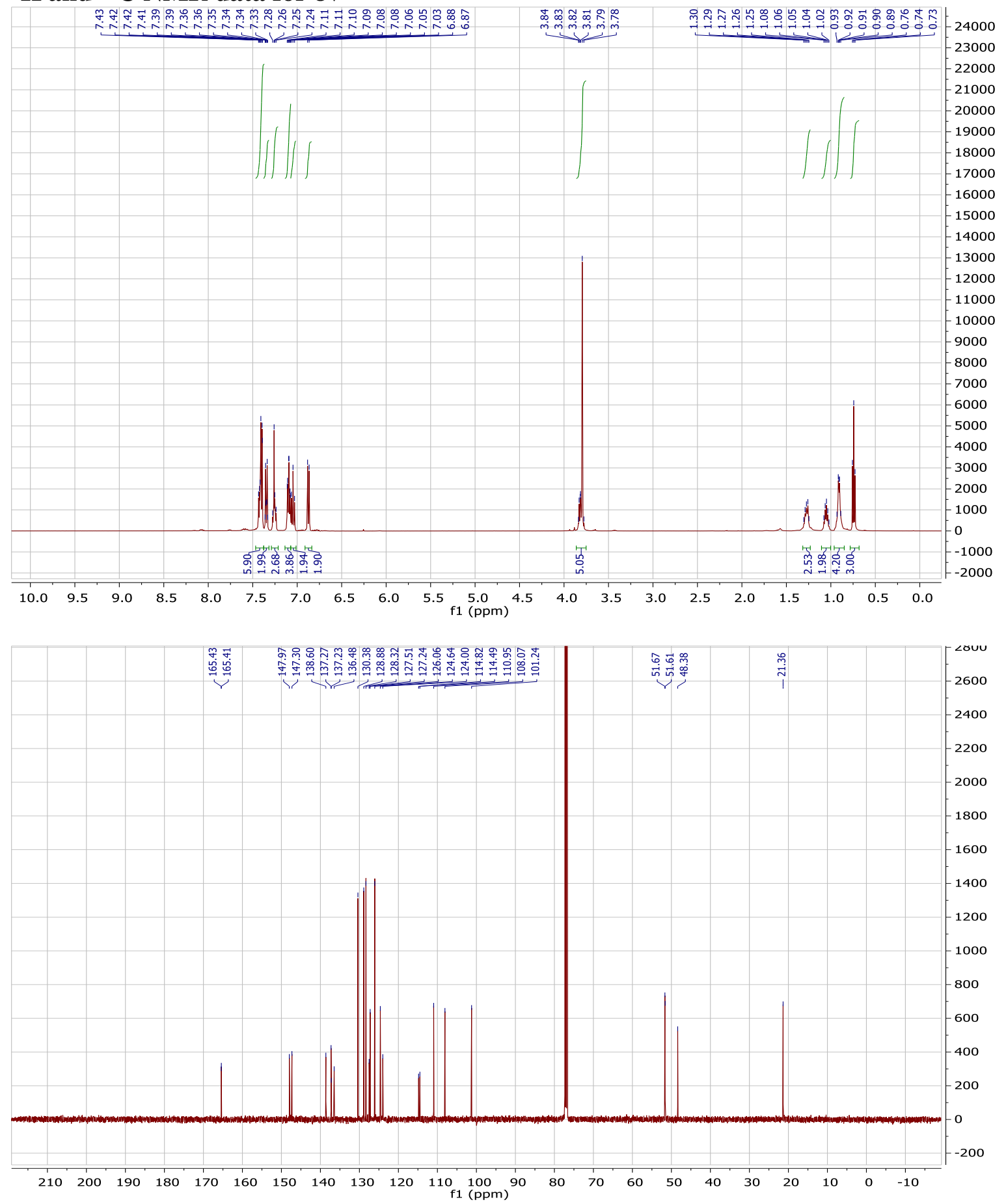


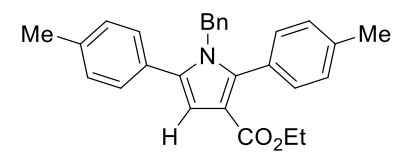

\section{${ }^{1} \mathrm{H}$ and ${ }^{13} \mathrm{C}$ NMR data for $8 \mathrm{w}$}
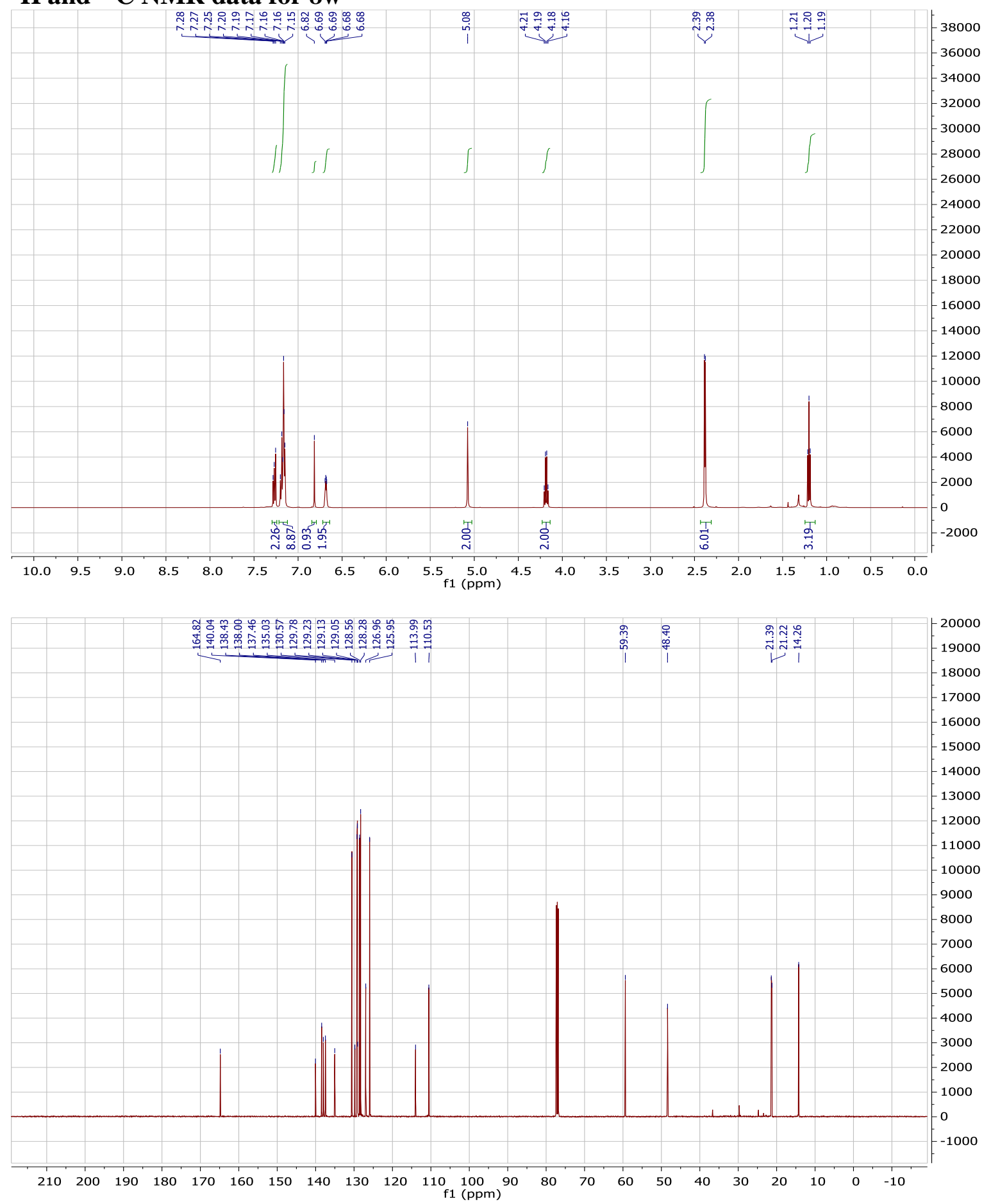


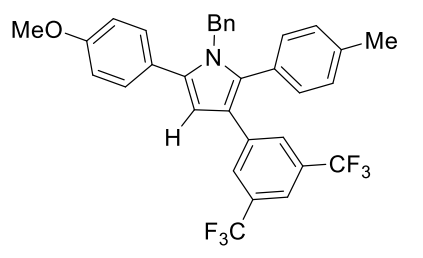

\section{${ }^{1} \mathrm{H}$ and ${ }^{13} \mathrm{C}$ NMR data for $8 \mathrm{x}$}
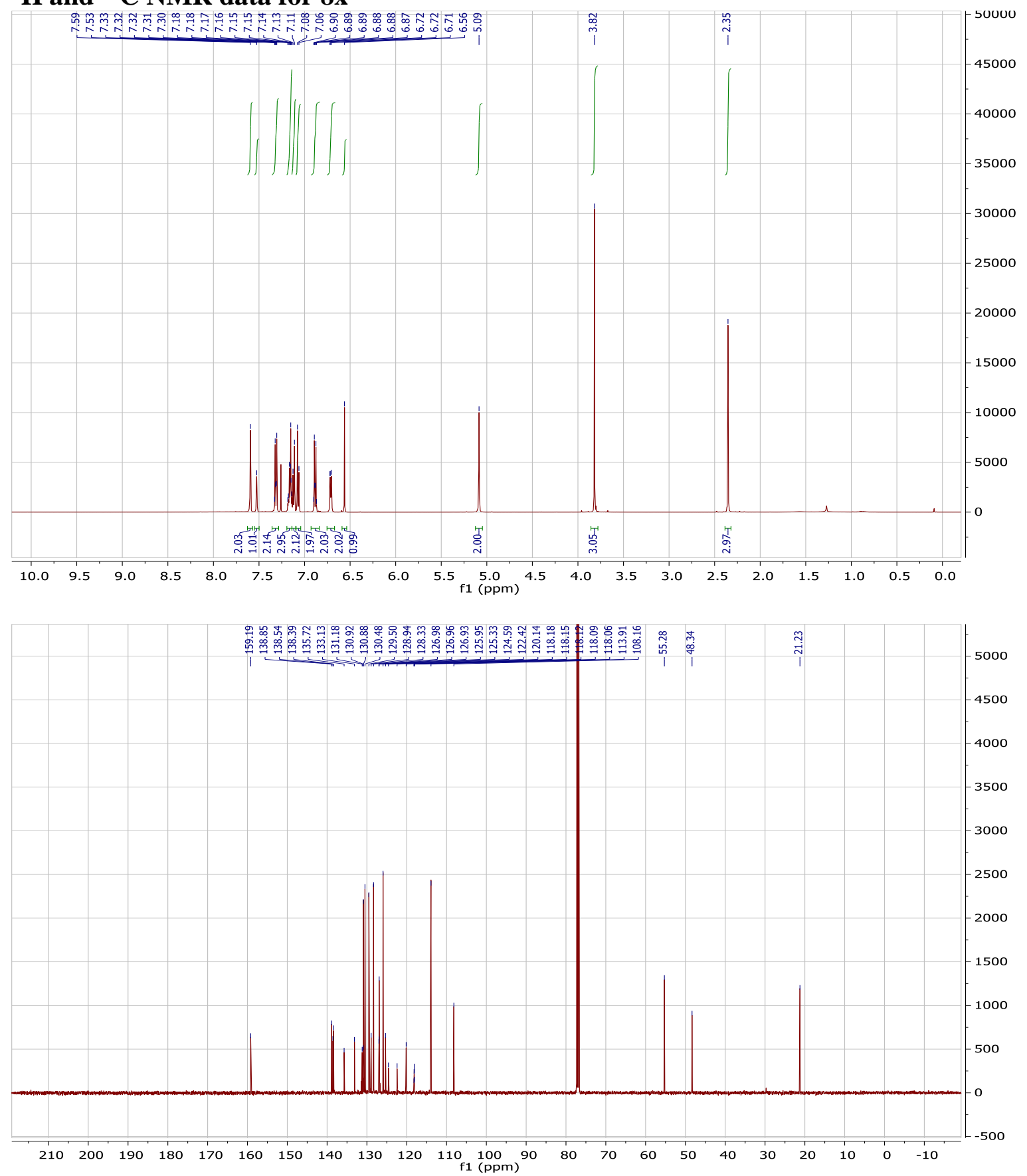


\section{NOESY spectrum of $8 x$}
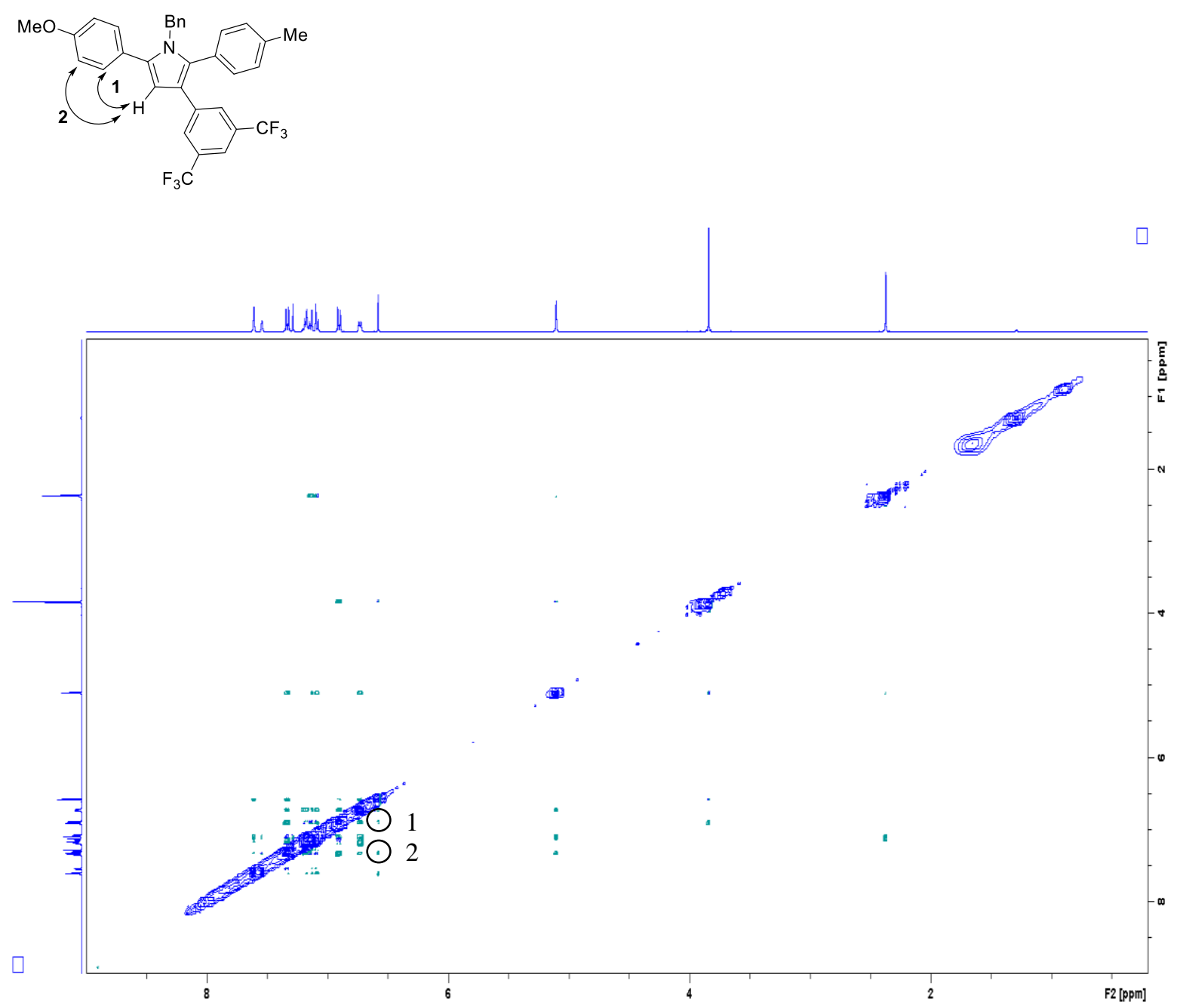


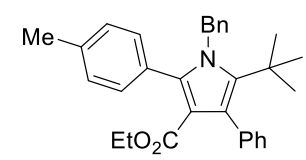

\section{${ }^{1} \mathrm{H}$ and ${ }^{13} \mathrm{C}$ NMR data for $8 y$}
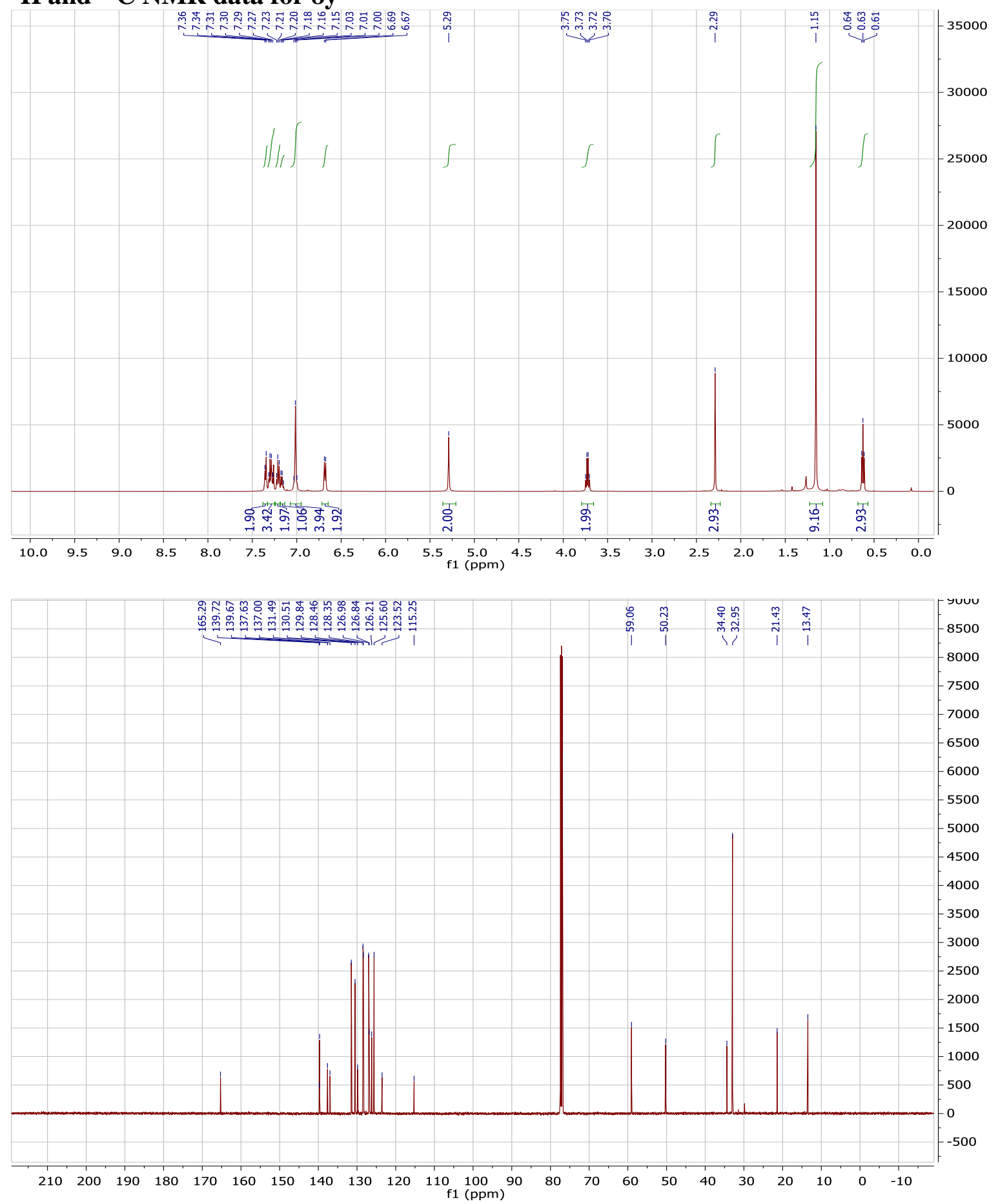


\section{NOESY spectrum of $8 y$}
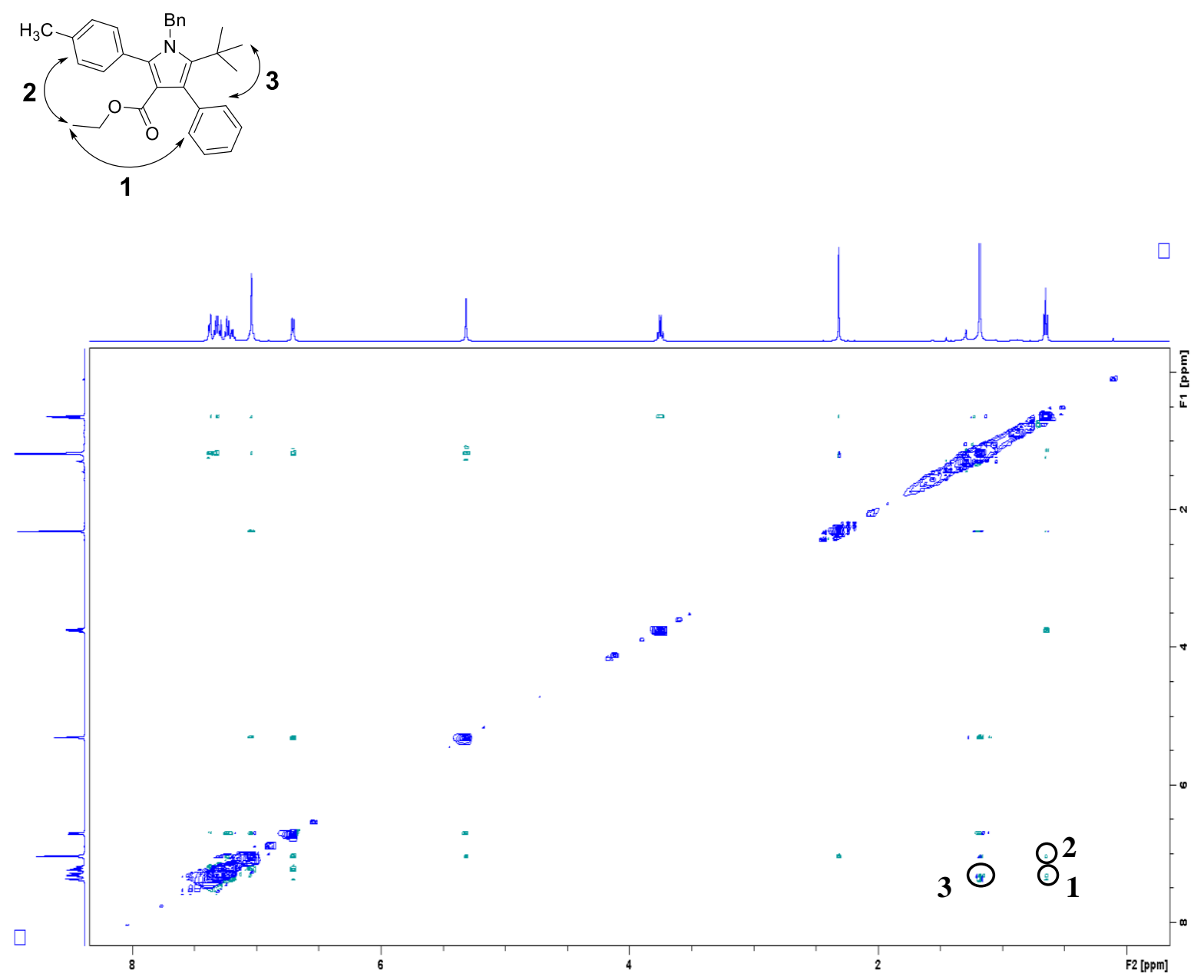


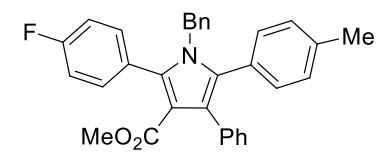

\section{${ }^{1} \mathrm{H}$ and ${ }^{13} \mathrm{C}$ NMR data for $8 \mathrm{z}$}
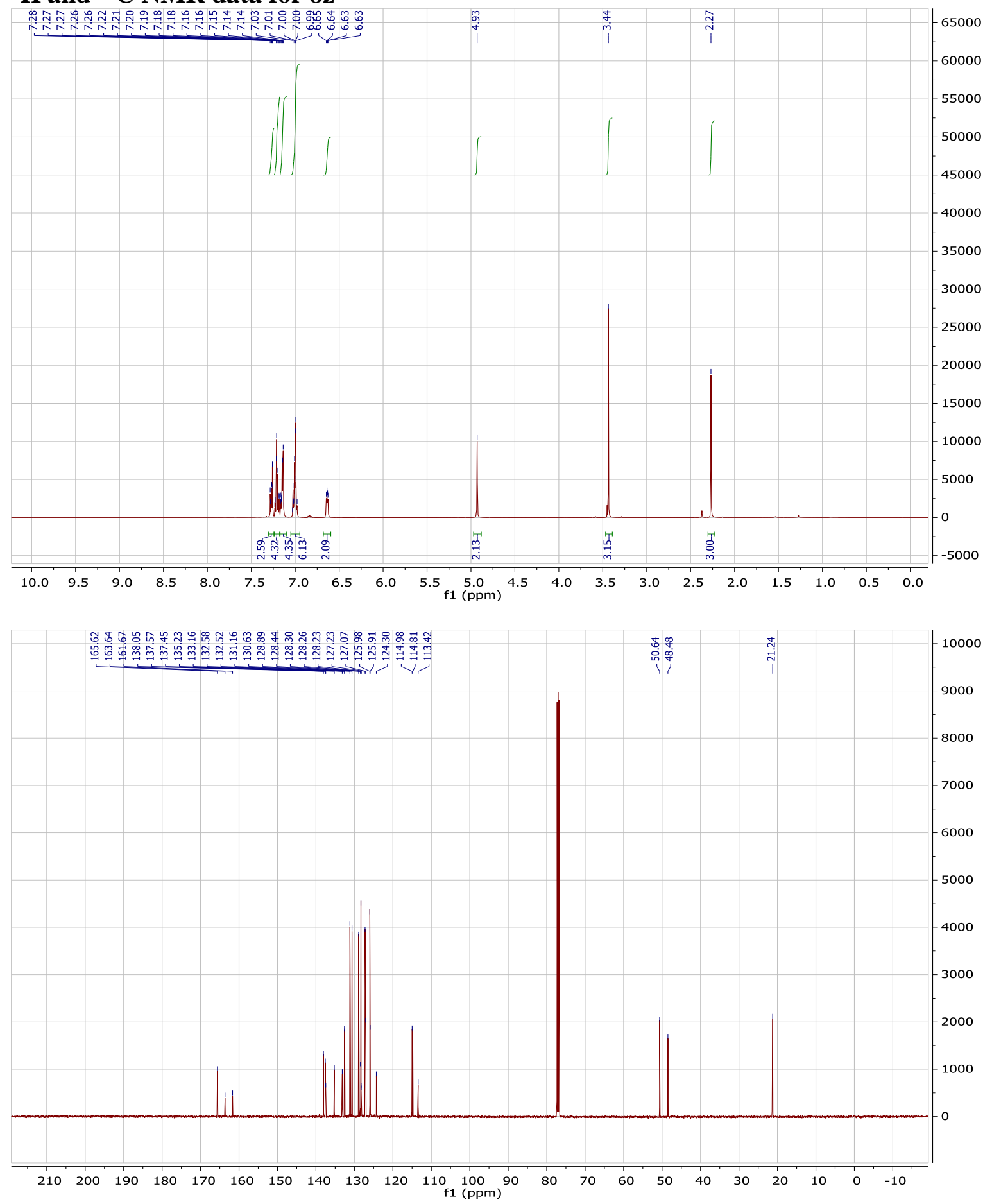


\section{NOESY spectrum of $8 z$}
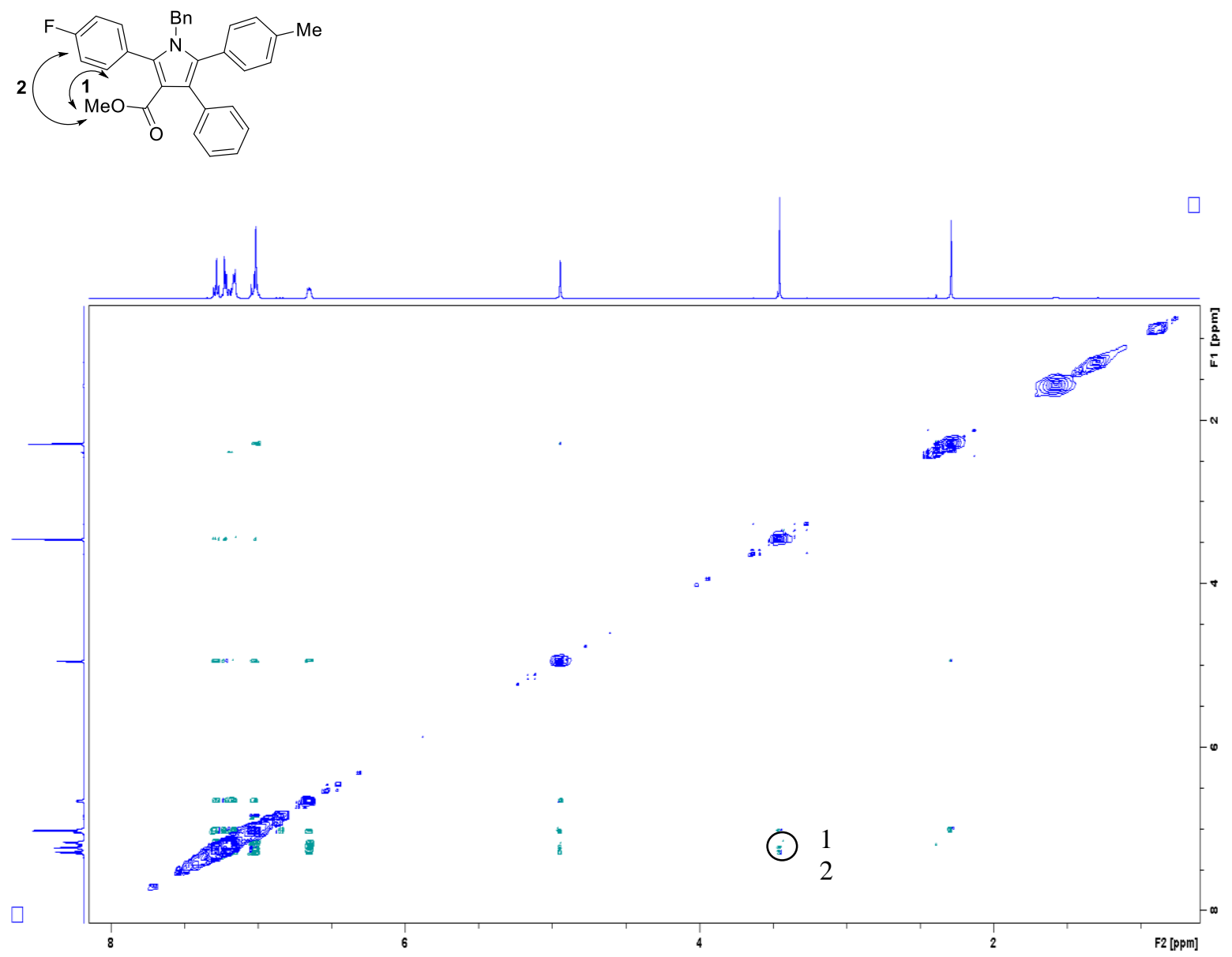
<smiles>CC(=O)c1c(-c2ccccc2)c(-c2ccc3c(c2)OCO3)n(Cc2ccco2)c1-c1ccccc1</smiles>

\section{${ }^{1} \mathrm{H}$ and ${ }^{13} \mathrm{C}$ NMR data for 8aa}
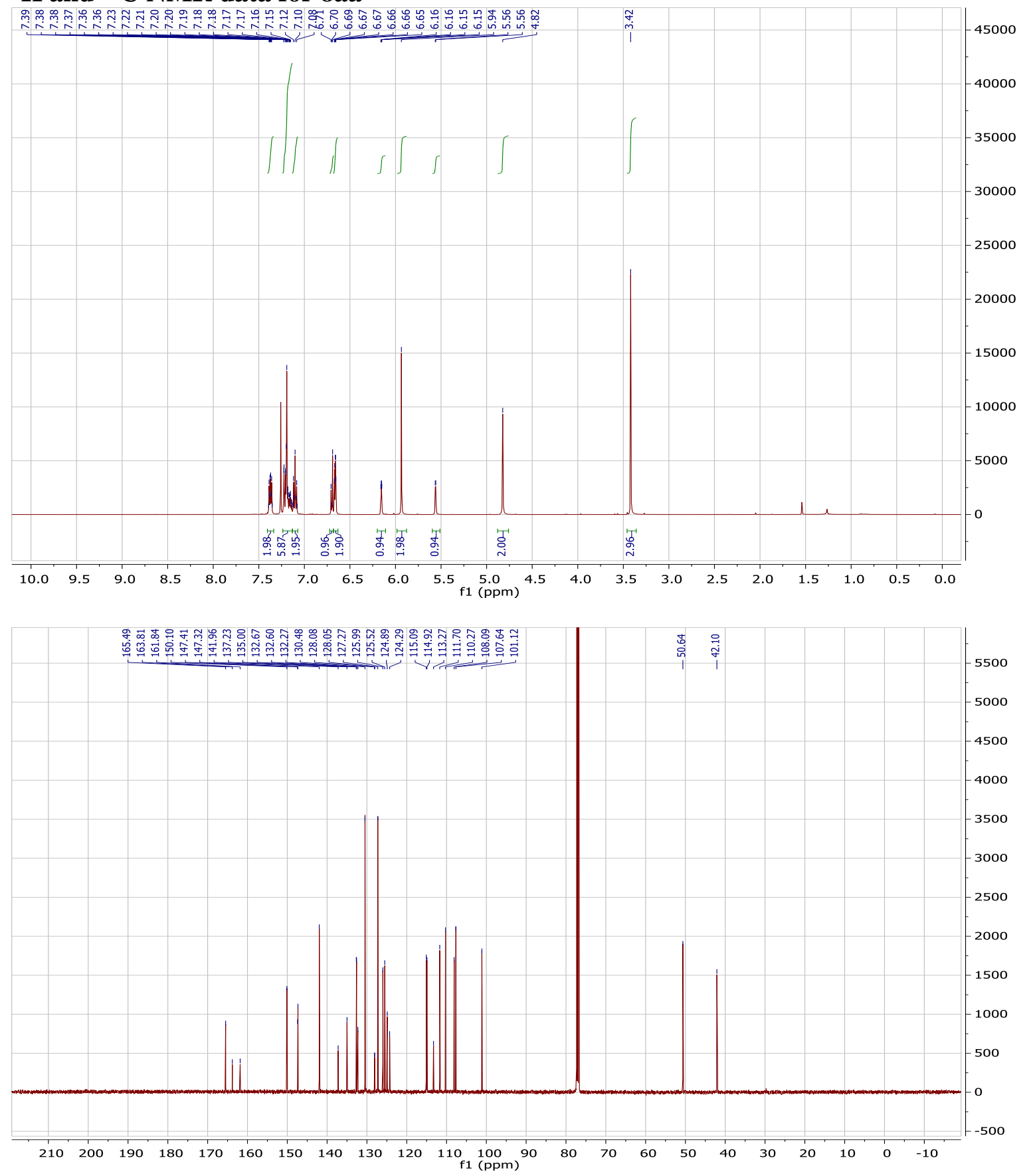


\section{NOESY spectrum of 8aa}
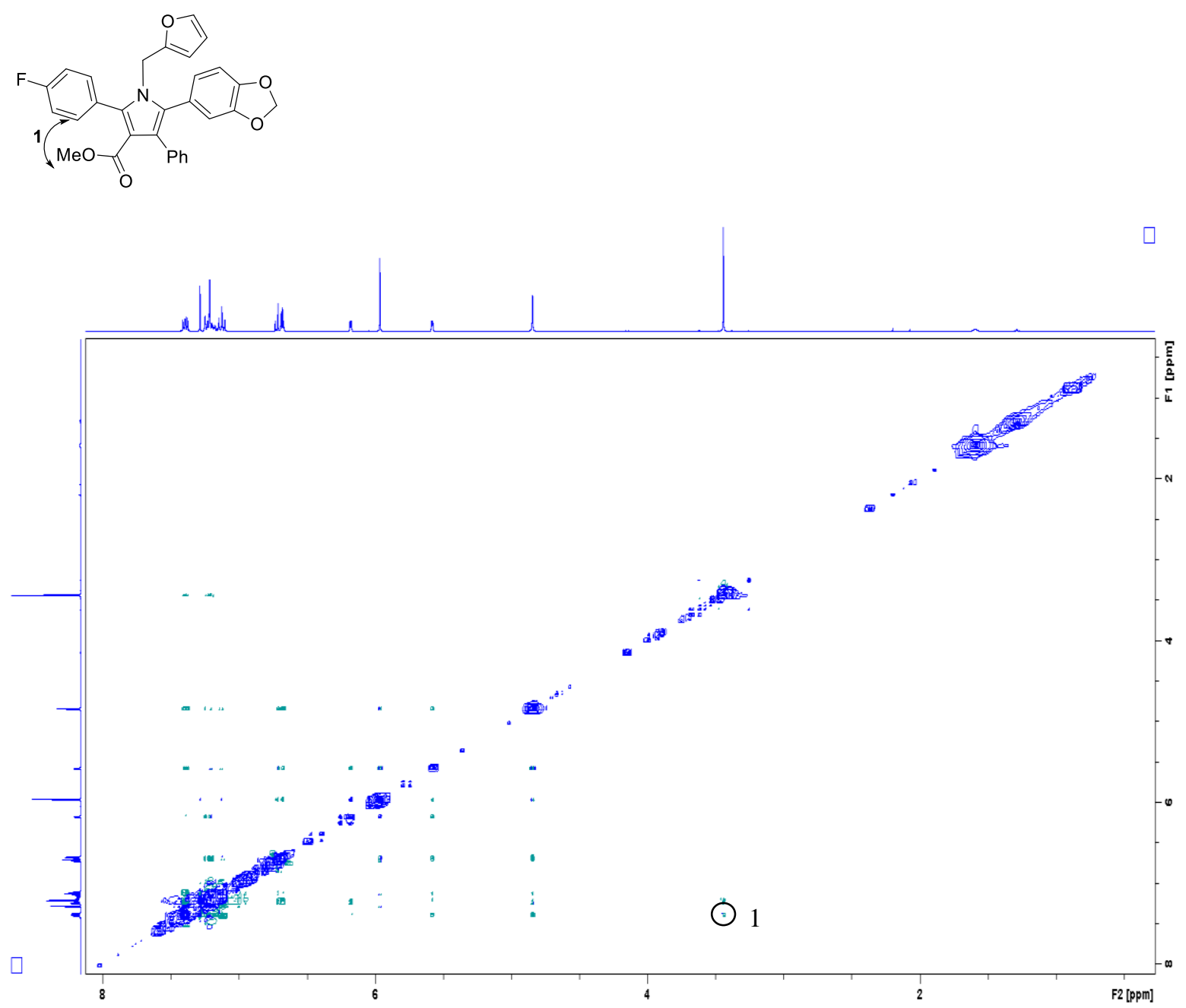


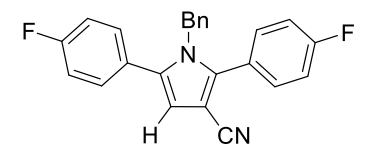

\section{${ }^{1} \mathrm{H}$ and ${ }^{13} \mathrm{C}$ NMR data for $8 a b$}
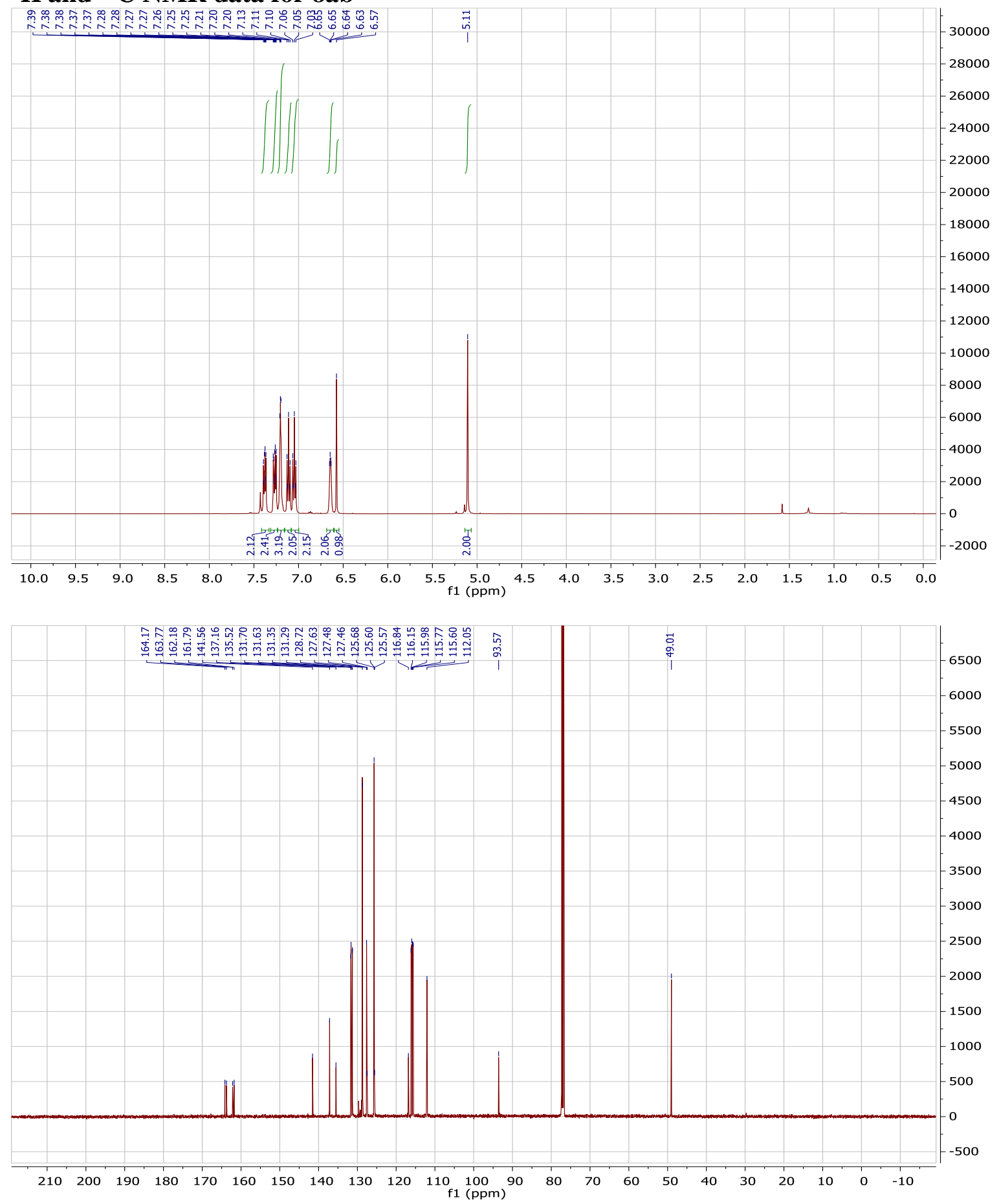
<smiles>COc1ccc(-c2c(C#N)c(-c3ccccc3)n(Cc3ccccc3)c2-c2ccccc2)cc1</smiles>

\section{${ }^{1} \mathrm{H}$ and ${ }^{13} \mathrm{C}$ NMR data for 8ac}
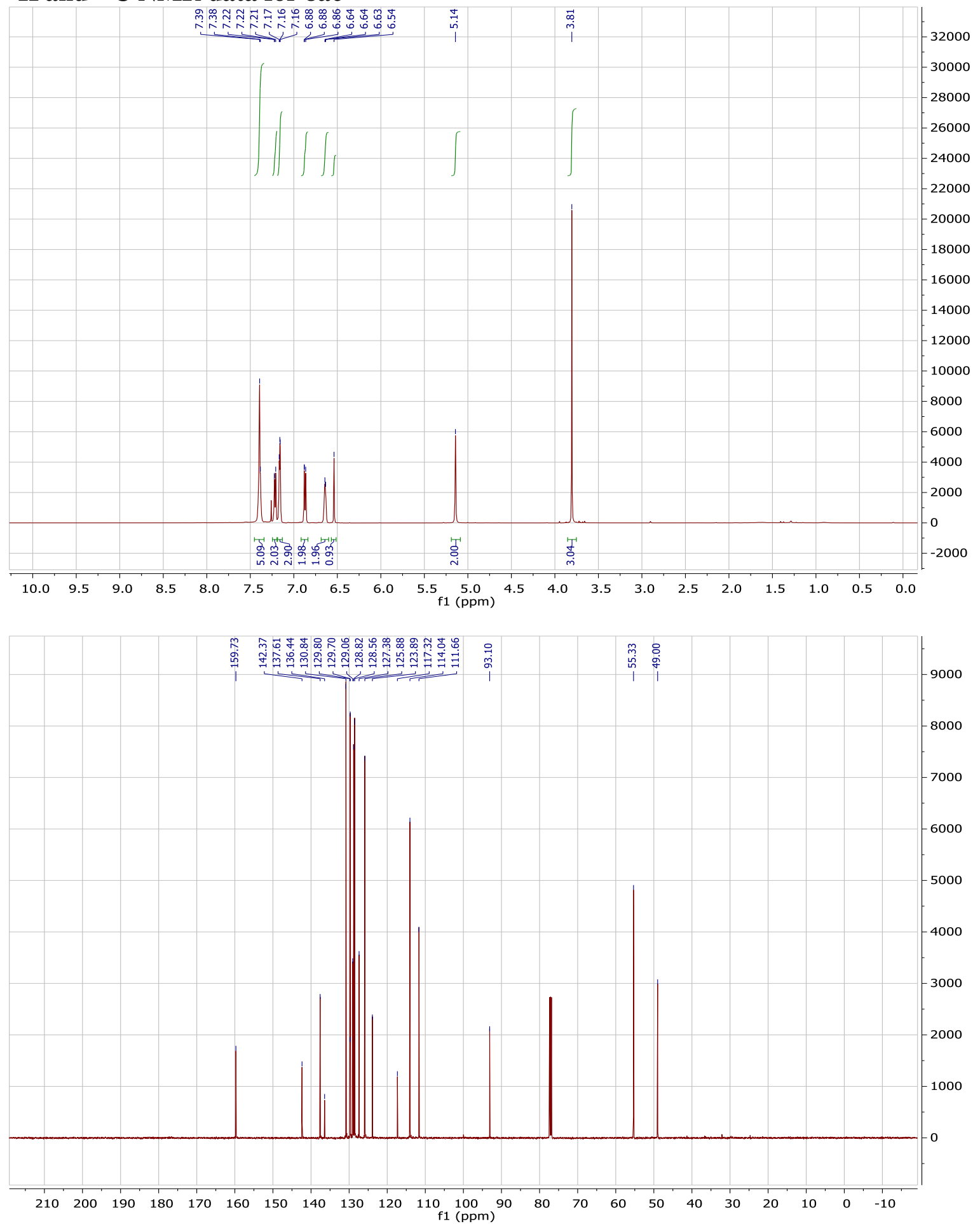


\section{NOESY spectrum of 8ac}
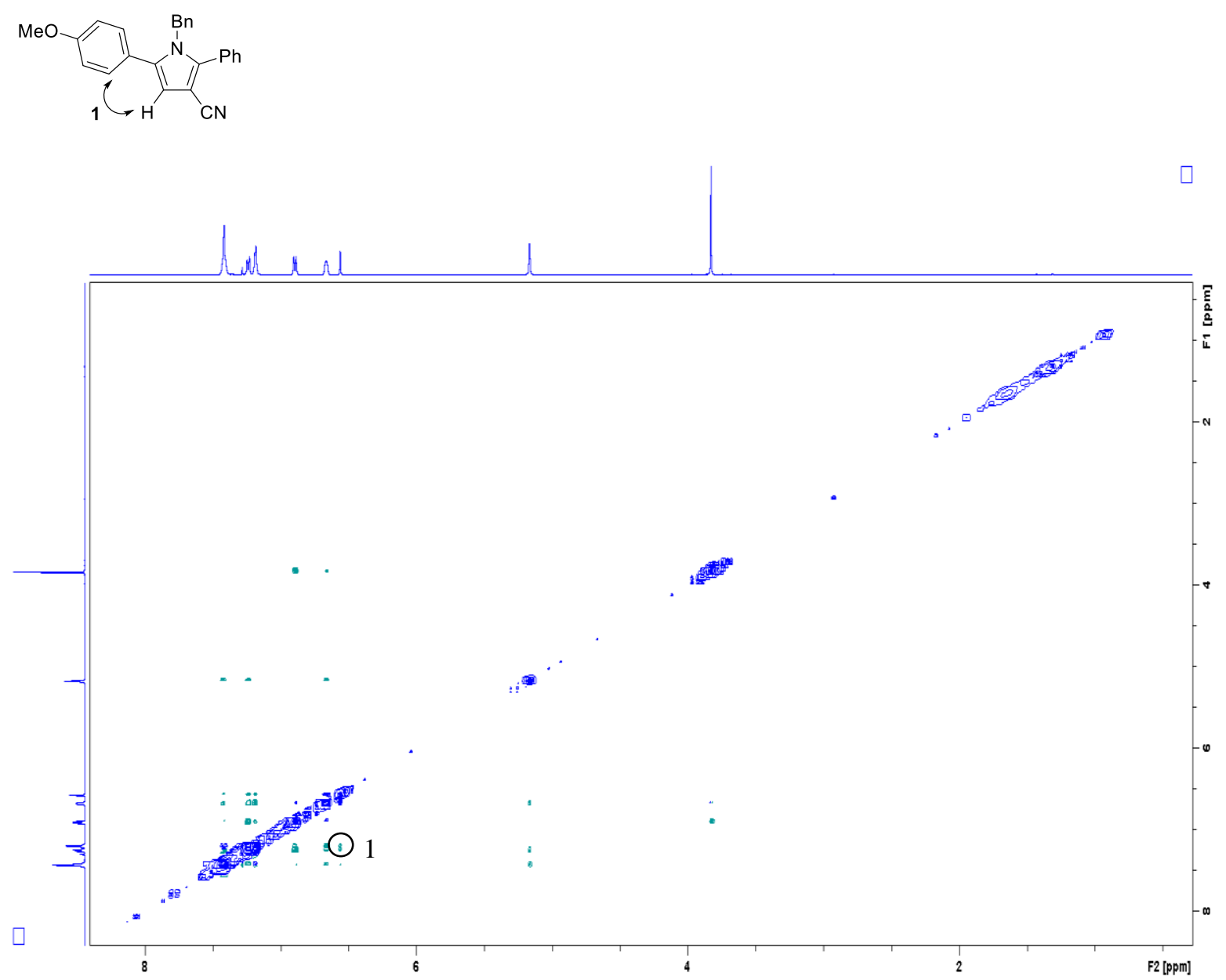
<smiles></smiles>

\section{${ }^{1} \mathrm{H}$ and ${ }^{13} \mathrm{C}$ NMR data for 8ad}
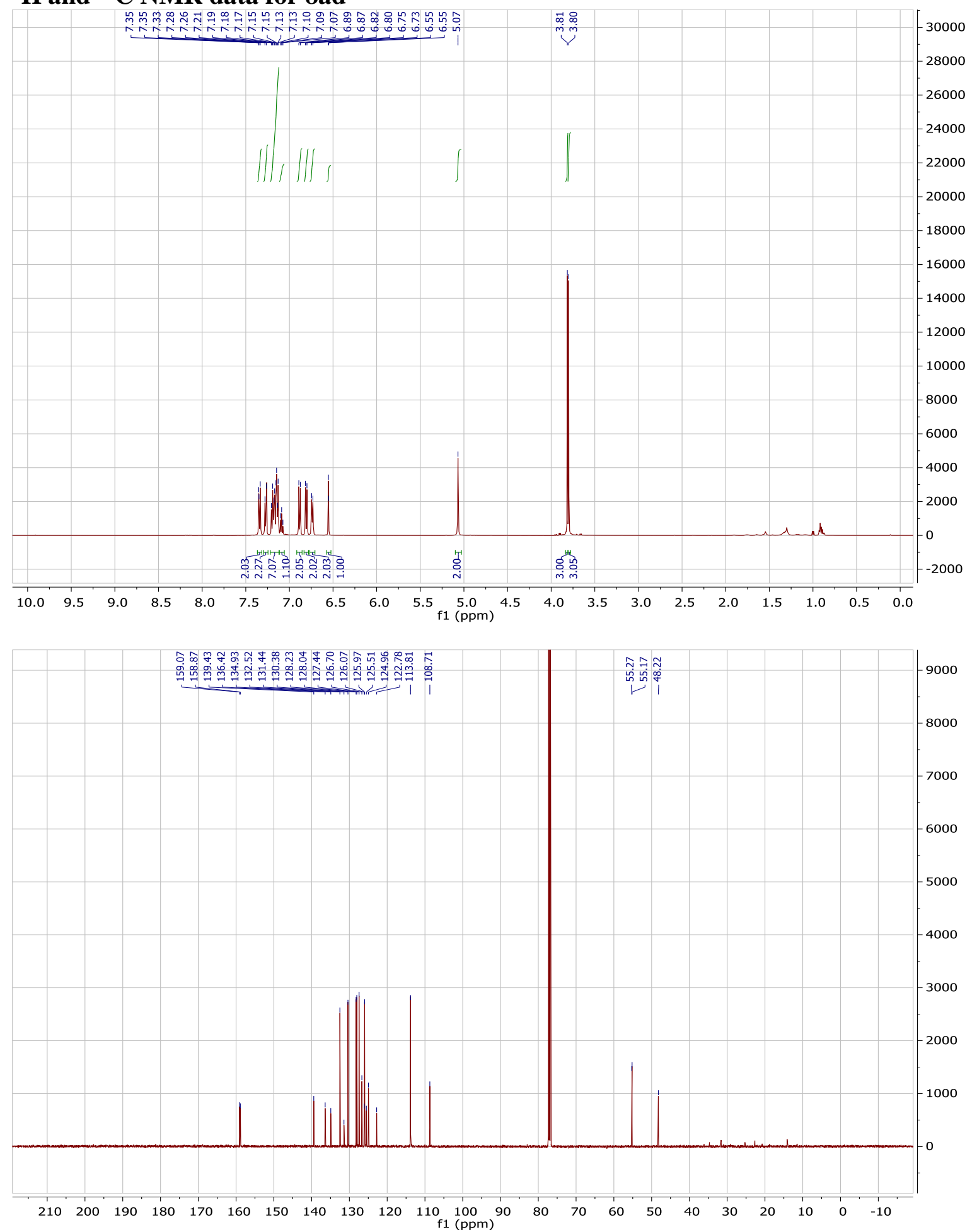


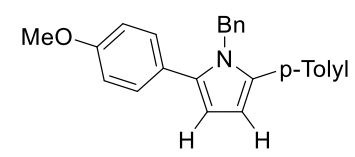

\section{${ }^{1} \mathrm{H}$ and ${ }^{13} \mathrm{C}$ NMR data for 8ae}
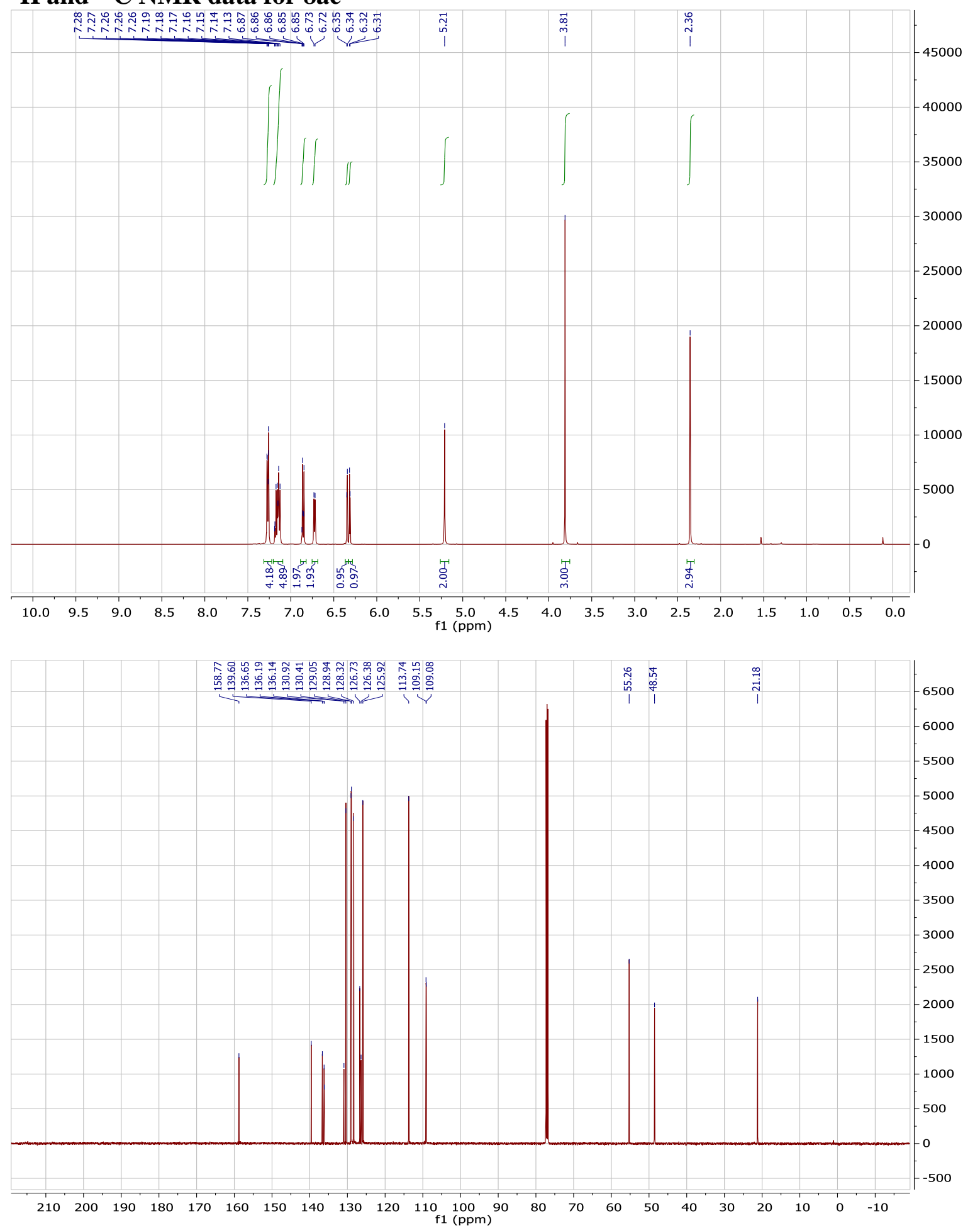


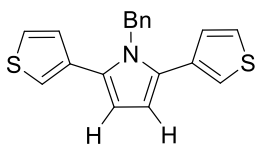

\section{${ }^{1} \mathrm{H}$ and ${ }^{13} \mathrm{C}$ NMR data for 8af}
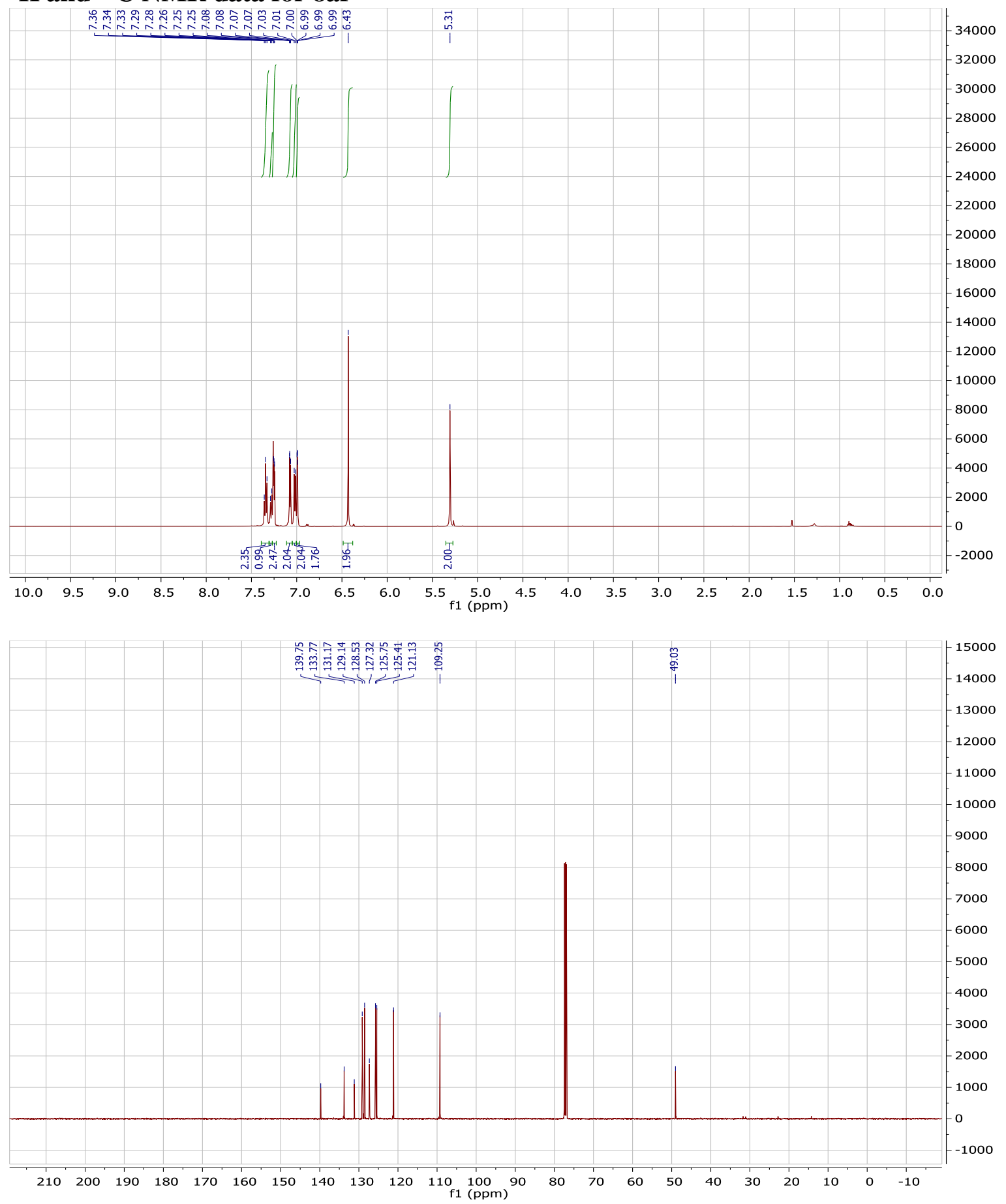